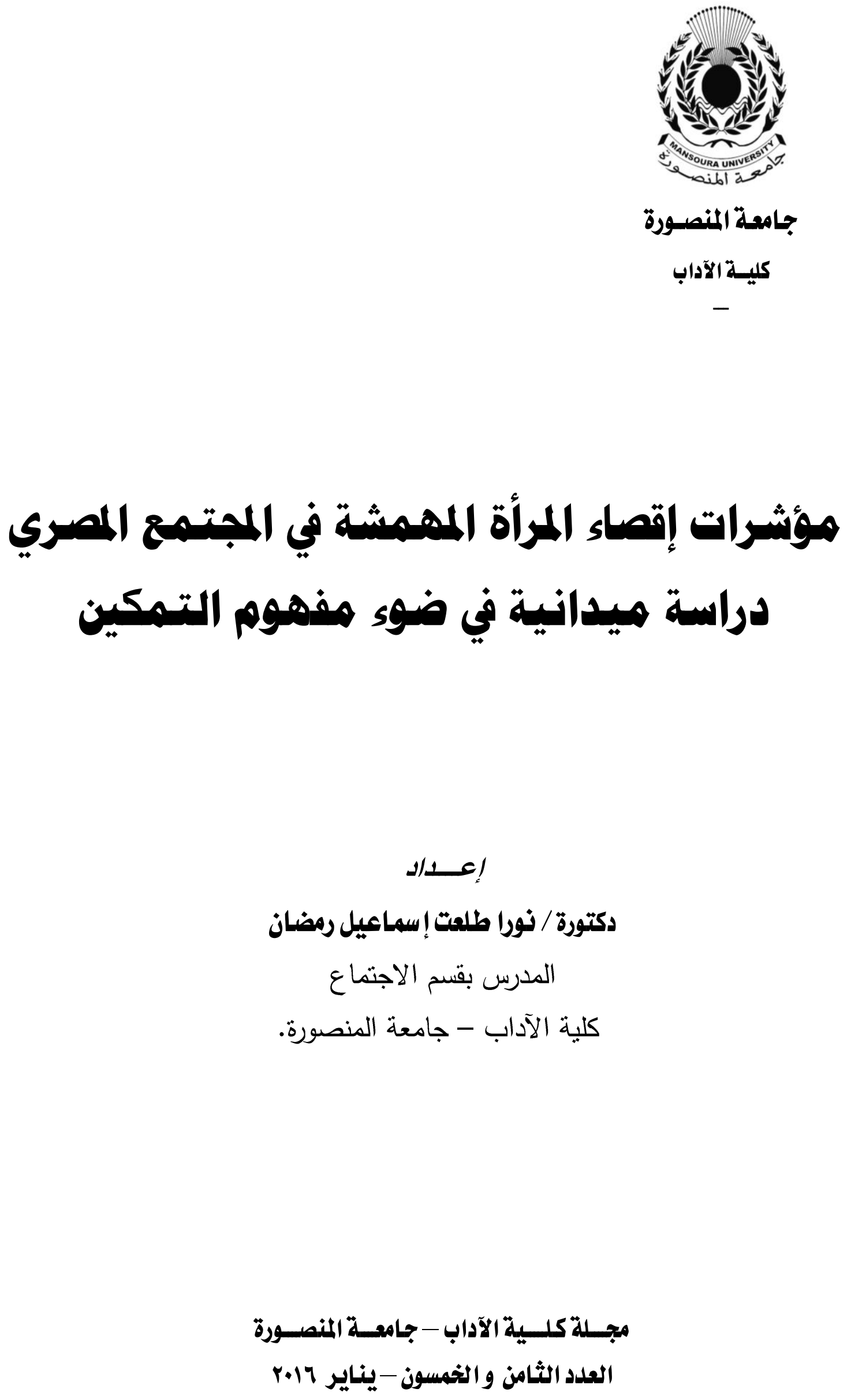




\section{مؤشرات إقصاء المرأة المهمشة في المجتمع المصري \\ دراسة ميدانية في ضوء مفهوم التمكين}

\section{د. ذورا طلعت إسماعيل رمضاز}

$$
\begin{aligned}
& \text { ملخص الببثث: } \\
& \text { بثثت هذه الدراسة في موضوع المؤشرات الدالة على إقصاء المرأة المهشة في المجتمع المصري ، و قد استهدفت الباحثة من خلاكها }
\end{aligned}
$$

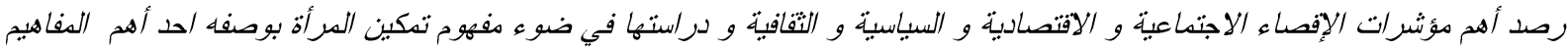

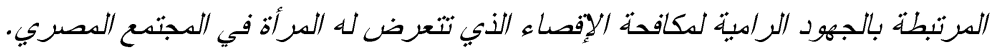

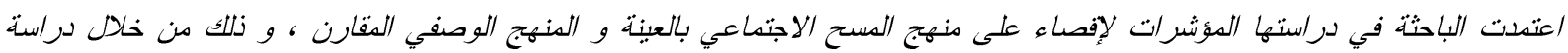

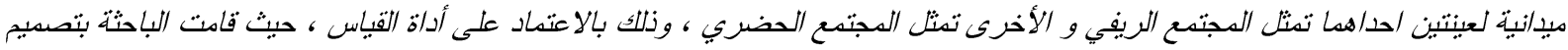

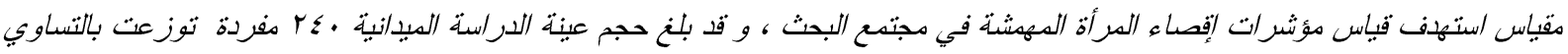

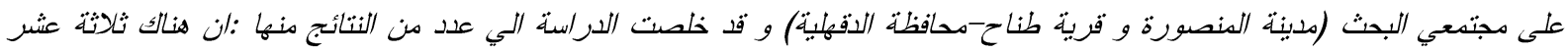

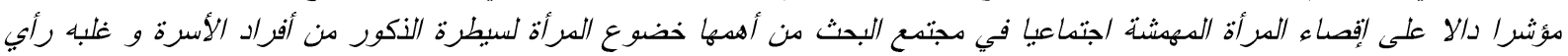

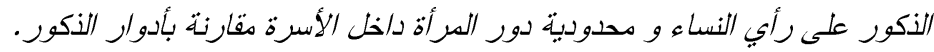

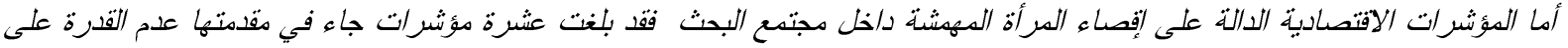

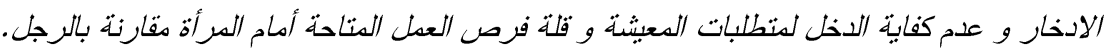

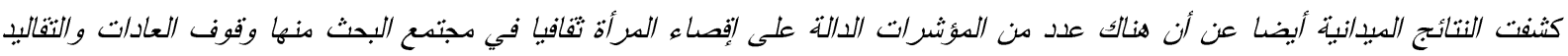

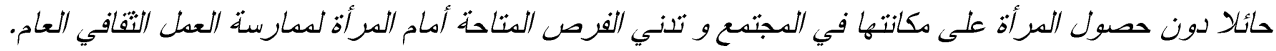

\section{Abstract}

This study examined the topic of indicators indicating the exclusion of marginalized women in Egyptian society, and the researcher aimed to monitor and study the most important indicators of social, economic, political and cultural exclusion in the light of the concept of empowering women as one of the most important concepts related to efforts to combat exclusion to which women are exposed in Egyptian society.

The researcher adopted in her study the indicators to exclude the social survey method in the sample and the comparative descriptive approach, and that through a field study of two samples, one of which represents the rural community and the other represents the urban community, by relying on the measurement tool, where the researcher designed a scale aimed at measuring the indicators of excluding marginalized women in the research community, The size of the field study sample reached 240 items distributed equally to the research communities (Mansoura City and Tanah Village - Dakahlia Governorate).

The study concluded a number of results, including: There are thirteen indicators indicating the exclusion of socially marginalized women in the research community, the most important of which is the subjugation of women to male control of family members, the dominance of male opinion over the opinion of women, and the limited role of women within the family compared to the roles of males.

As for the economic indicators indicating the exclusion of marginalized women within the research community, they reached ten indicators, in the forefront of which were the inabilities to save and insufficient income for living requirements and the lack of work opportunities available to women compared to men.

The field results also revealed that there are a number of indicators indicating the cultural exclusion of women in the research community, including the standing of customs and traditions that prevent women from obtaining their position in society and the low opportunities available to women to practice public cultural work

$$
\begin{aligned}
& \text { المتحدة ، مثل معهد الأمم المتحـــدة الإنمـــائي } \\
& \text { كذلك امتد الاهتمام لبصــل إلــى عــدد مــن } \\
& \text { الإصدارات التي قدمها كل من البنــــ الـدولي } \\
& \text { وصندوق النقد الدولي. } \\
& \text { ويزداد موضو ع الإقصساء أهميــة عنــدما }
\end{aligned}
$$

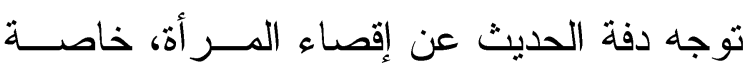

$$
\begin{aligned}
& \text { المر أة في المجتمعات النامية أو الفقيــرة علـ }
\end{aligned}
$$
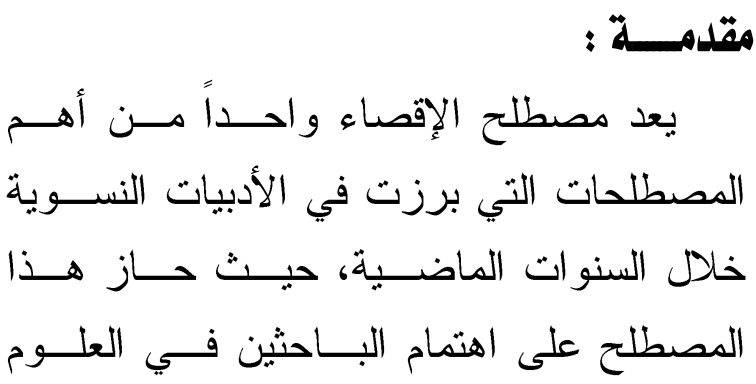$$
\text { الاجتماعية، فضلا عن الهئُــات و المؤسســات }
$$

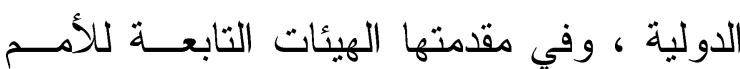


من القطاع العام عبر برنامج نشط أطلق عليـهـ في تلك الفترة برنامج الخصخصة. وبالرغم من التحذيرات التي أطلقت من قبل المفكرين و الباحثين لخطورة النتــائج الوخيمــة

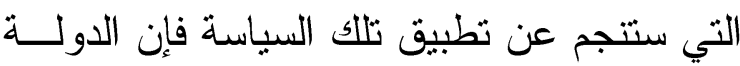

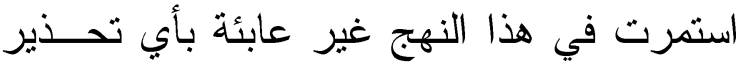

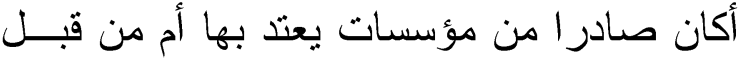
أوراق بحثية أو مؤتمرات أو ندو ات. ولعل الأثر الأكبر الذي نجم عــن سياســـة

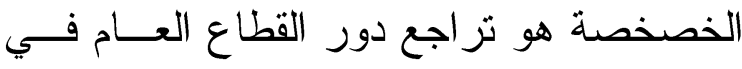

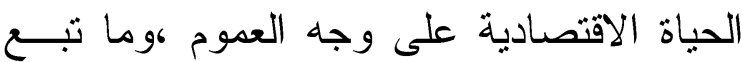
ذللك من تداعيات على مختلف منــاحي الحيــاة الاجتماعية، ويعود ذللك إلى تراجع التوظيف في القطاع العام الذي كان في السابق أكبر عدد من

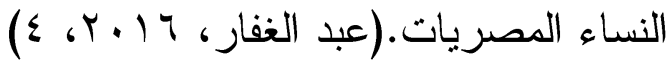

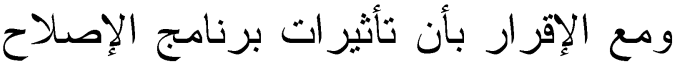

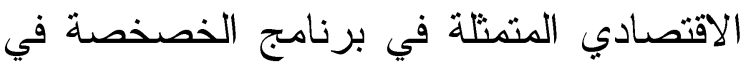
تللك الفترة طالت كافة شر ائح المجتمع المصري فئري خاصة من أبناء الطبقة الوسطى و الدنيا، إلا أن تأثيرات تلك التجربة كانت أكثر فداحة بالنسـبـة التباء للمر أة في مصر ، وذلك أخذا في الاعتبار أن هذا

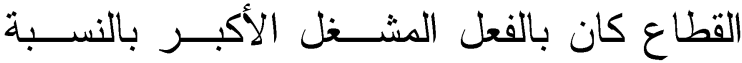
للنساء.

وقد انقضى أكثر من ثمان وعشرين ســنة على البدء في تجربة الإصــلاح الاقتصــادي،

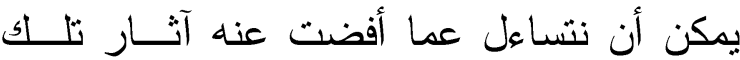

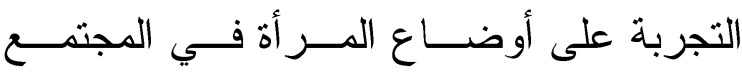

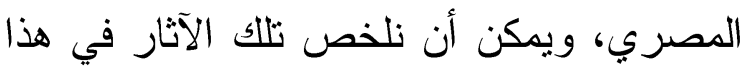
المصطلح الذي بدأت الباحثة مقدمة هذه الدر اسة بالحديث عنه، ألاو هو مصطلح الإقصاء.
وجه العموم، ومن بينها المجتمعات العربية التي تؤكد التقارير على أن المر أة في تلك المجنمعات لا نزال تعاني من انعدام المساواة المتجذرة في القو انين و المؤسسات التي تميز بين الجنسـين،

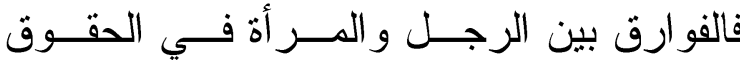

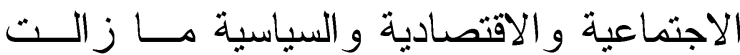
كبيرة ومستشرية في المنطقة العربية. (الإسكو، $(V, T \cdot) \varepsilon$ و السؤال هنا لماذا هذا الاهتمام بموضــوع

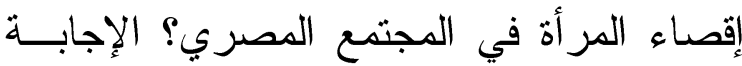
على هذا السؤال تتطلب البحث فــي الســياقات الإهات المجتمعية المحيطة بالمر أة وخاصة المر أة فـي لـي

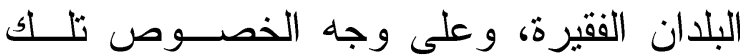
البلدان التي طبقت أو حاولت تطبيـق حزمهــة البرامج التي يوصي بها البنك الدولي وصندوق النقد الدولي، خلال العقود الماضية التي تمتــد منذ بداية العقد الأخير من القرن العشرين. فإذا أخذنا المجتمع المصري عالــى ســبيل المثال فسنجد أن الدولة منذ بداية تسعينات القرن العشرين نهجت عدداً من السياسات الاقتصادية تطبيقا لتوصيات كل من البنك الدولي وصندوق

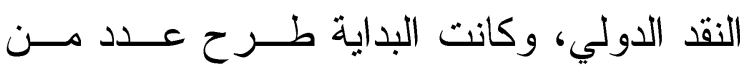

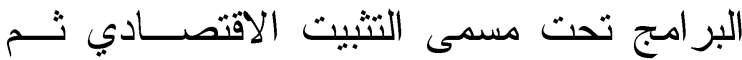
التكيف الهيكلي، وقد هدفت الدولة من خلال تلاك

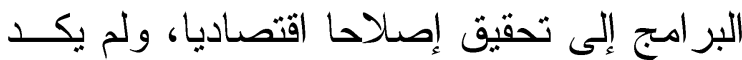

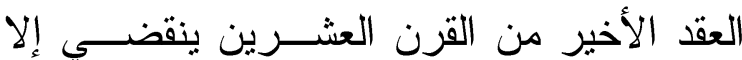

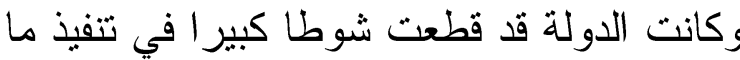
عرف في تلك الفترة بروشتة البنك الدولي. وقد شملت تلك الروشتة توصــية بتصـفية بلتية

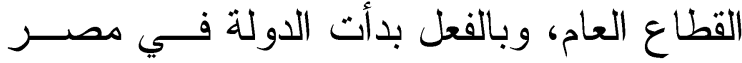

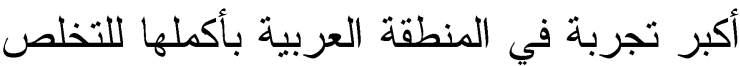


عام و المر أة في المجتمع المصري على وجه الخصوص، مع الاخذ في الاعتبار أهمية التتاول العلمي لما يثار من قضايا حول

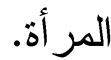

r- المبررات التطبيقية: أ. يمثل تصميم مقياس لرصد مؤشرات اقصاء المر أة المهششة في المجتمع المصري محاولة مدئة جيدة من قبل الباحثة تمهذ الطريق أمام الباحثين لاختبار قدرة هذه المقياس على هلى قياس درجة اقصاء المر أة في مختلف مناحي الحياة الاجتماعية وهو عمل لم يسبق فيه الباحثة أحد حتى كتابة هذا السطور في وهو المجتمع المصري. ب. إن النتائج التي ستخلص إليها هذه الدراسة ستكون في غاية الأهمية بالنسبة للمؤسسات

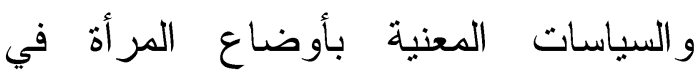
المجتمع المصري، حيث يمكن الاخذ بها عند به بهاب الاقدام على تصميم السياسات و البرامج التي تهدف إلى تحسين أوضاع النساء والارتقاء بهن على وجه العموم.

\section{ثانيا :مشكلة الدراسة}

\section{مشكلة الدراسة وتساؤلاتها :}

الحديث عن إقصاء المرأة في

المجتمعات النامية و الفقيرة حديث ليس بجديد، فقد تضمنت العديد من الدراسات و التقارير الدولية والمحلية إثار ات ولو غير مباشرة عن إقصاء النساء، فعلى سبيل المثال تشير حنان الجريسي إلى أن الأسرة تأتي في مقدمة المؤسسات الاجتماعية المرتبطة بتشكيل

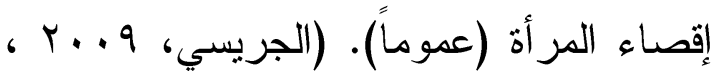

في دراسة مبكرة إلى حد ما عن مؤشرات

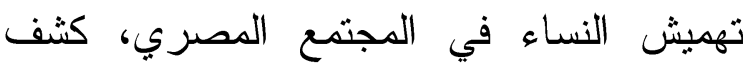

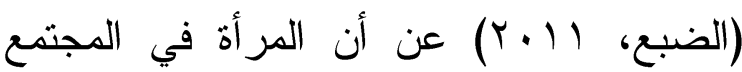
المصري تعاني من أكثر من أربعين مؤشرا للتهميش، توزعت على أربعة إبعاد أساسية هي: التهميش الاجتماعي و التهميش الاقتصادي لوني و التهميش الثقافي و التهميش السياسي. وقد أفاضت العديد من الدراسات العربية والأجنبية عن الصور المتتوعة للتهميش الذي تعاني منه النساء في المجتمعات الفقيرة على وجه العموم، وبالرغم من كثرة تلك الدراسات خاصة المعنية بقضايا التمكين، فإن الباحثة لم يقع تحت يدها دراسة تتتاول مؤشرات إقصاء في المجتمع المصري، هذا مع الإقرار بأن كافة الدراسات التي بحثت في موضو عات ذات صلة بقضية تمكين المرأة، أشارت في مضامينها إلى مولى الصور المتنوعة لإقصاء النساء على وجه

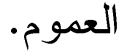

في ضوء ذللك جاءت فكرت هذه الدراسة التي تبحث في موضوع مؤشرات إقصاء المرأة المهشة في المجتمع المصري.

\section{أولا : مبررات الدراسة:}

1- المبررات العلمية:

أ. أهمية موضوع البحث وهي الأهمية التي عبرت عن نفسها من الاهتمام الواسع من قبل الباحثين وكثير من مر اكز البحث العلمي و المؤسسات الدولية و المحلية بمشكلة اقصاء مرني

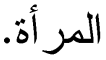
ب. ستعد هذه الدراسة اسهاما من الباحثة في التزاث السسيولوجي الخاص بالمرأة بوجه 
الاجتماعية، وليس القدرة الأكاديمية، فينظر إلى النساء بوجه عام على أن هويتهن ومكانتهن تتحدان وفقاً لأدائهن أدواراً نمطية الى لهاء

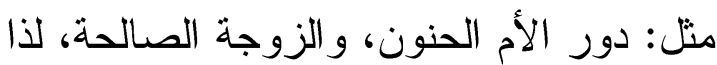
فإن الإداريين، و المعلمين، والآباء، والفتيات أنفسهن لا يرون جميعاً سبياً أو حاجة لأباء، ولأن تخوض الفتيات في أمور مثل الدراسة المعدقة

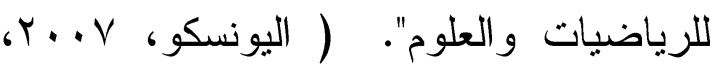

وفي ذات السياق يؤكد تقرير صادر عن البنك الدولي على أن العرف يشكل أحد المواقف الاجتماعية التي تتشكل من خلاله صور متتوعة من إقصاء المرأة في التعليم التئه حيث تعمل الأعراف كمدد لعلاقات السلطة بين الجنسين،وتفرض نوع العمل الذي يعد

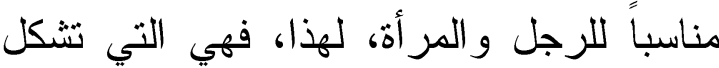

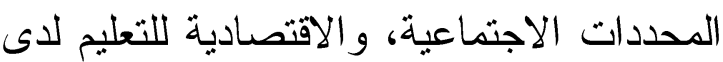
الفتاة والفتى، وبشكل خاص أحقية أي منهما

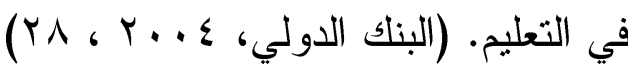

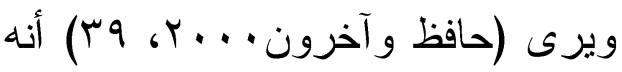
في العديد من المجتمعات، عادة ما يتحدد دور المر أة بناء على أدوارها النوعية التي تجعلها تتخذ مسارات اجنماعية عدة، تسهم في تحديد

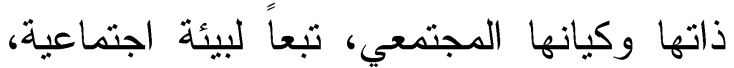

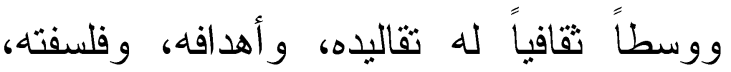

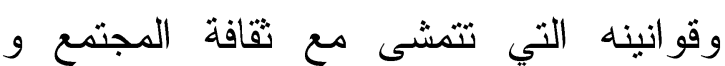
أهدافة و فلسفته.

وقد نرتب على كل تلأك الأوضاع أن

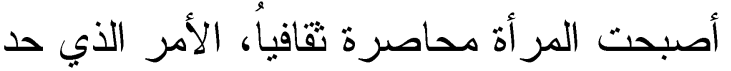

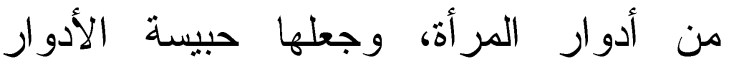
التقليدية التي تتمثل في الإنجاب، ورعاية
ع|(10-10) فالأسرة تقوم بدور مهم في

تدعيم الفجوة النوعية بين الجنسين بتحديدها

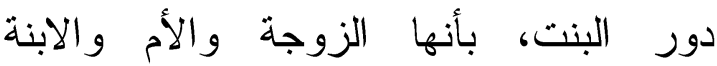

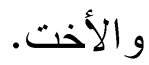

كما أثارت رفيقة حمودة إلى أن

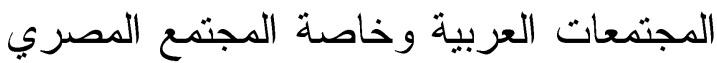

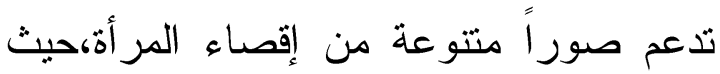
يتم دعم فكرة مؤداها أن دور النساء ينحصر

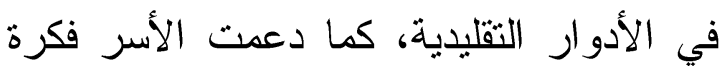
أخرى تعزز ذلك الإقصاء مفادها أن المرأة الأنرة

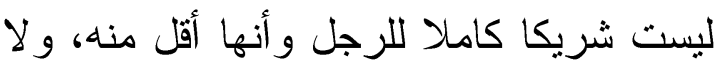
يحق أن يكون لها إطار معرفي متكامل عن ذاتها وعن مجتمعها يساعدها في إدارة

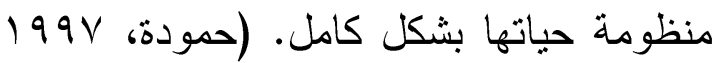
(10)، وتؤكد منى عبد الرحمن على أنه وفي

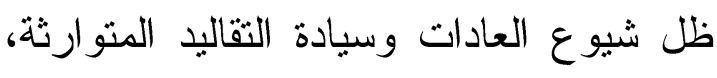
اقتصرت أدوار المرأة في المجتمع العربي

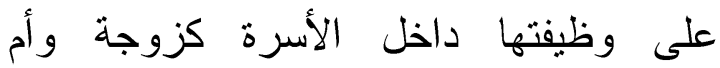
فحسب، " فهي المسؤولة عن إدارة المنزل، وتدبير شؤونه الداخلية من ناحية تدبير

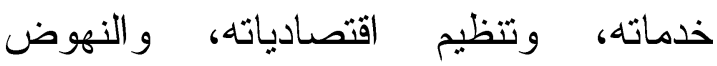
بمستوى المعيشة، وتتشئة، ورعاية، وتربية

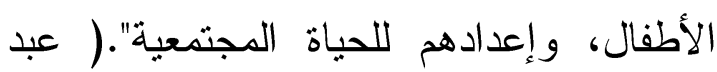

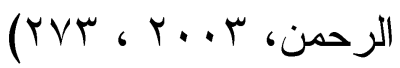
كما يعد مجال التعليم أحد أهم المجالات التي تتضح فيها أنماط وصور متتوعة لإقصاء المرأة في البلدان النامية والفقيرة، حيث يؤكد

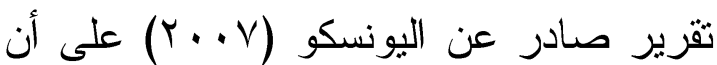
الصور النمطية التقليدية عن الجنسين في العالم النامي ،عادة ما تركز على الأدوار 
وهو سطوة المجتمع الأبوي خاصة في البلدان

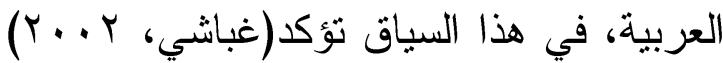
على أن النظام الأبوي _النظام السائد في كافة

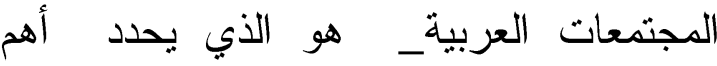
أسس السلطة في اتخاذ القرارات الاجتماعية،

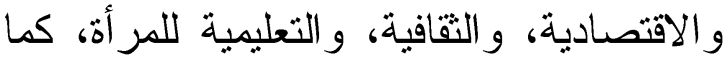
يحدد مساحة خاصة للمر أة، ويربط بين هويتها الاجتماعية من جهة، وارتباطها باسم رجل

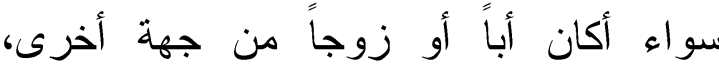
وبالتالي تحدد قيمتها الأساسية كإنسان. وقد وسعت بعض الدراسات من دائرة إقصاء المرأة من باب أن المرأة العربية تو اجه

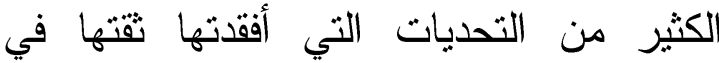
قدرتها على القيام بدور فاعل في الحياة العامة

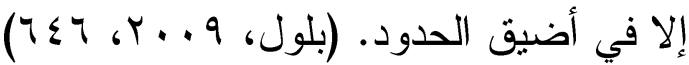
كما يشير تقريز صادر عن الأمم

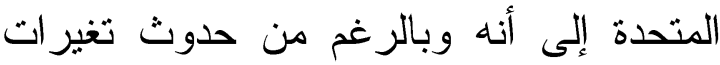
دخلت على الإطار التسلطي الحاكم علاقة الرجل بالمر أة، وأحدثت به تطوراً جذرياً، فإنه

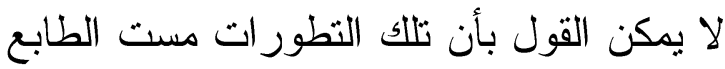
الوظيفي للعلاقة التسلطية بين الجنسين في لاني العمق، كما أنها لم تحدث تغييراً نوعياً في لإنيا طبيعة العلاقات بينهما إلا في أوساط محددة.

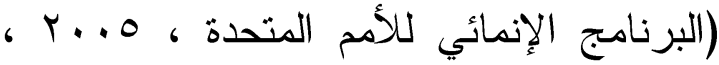

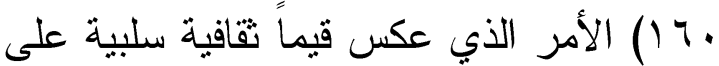
مكانة المرأة في إطار قيم النظام الأبوي، الذي لإني يدعم تفوق الذكر ، وتثبيت هيمنته على المرأة.

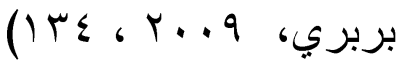
إن المحصلة النهائية لكل تلك التحليلات، أن البنية الثقافية للمجتمعات العربية ومن بينها المجتمع المصري، تعمل على تأكيد عملية
الأسرة، و الثؤون المنزلية، ورؤية خروجها، واختلاطها مسألة فساد أخلاقي بالرغم من الرناه

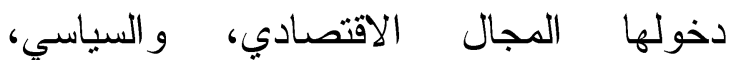
و التقافي، كما أوضحت دراسة (القليني، (r... r ولعل من أهم النتائج المنرتبة على سيادة هذا السياق الثقافي، بسطوة أعرافه، وتقاليده في تشكيل صورة ومكانة المرأة و مكانتها على وجه العموم، ما يتعلق بأيديولوجية توزيع القوى الاجتماعية، كما ذهبت دراسة (السنبل، فالمؤسسات الاجتماعية (r... تصوغ الأدوار، و العلاقة بين الرجل و المرأة، وعلاقات القوى بينهم، وتؤُز في الموارد الاجتماعية التي يحق للرجل و المرأة أن تكون

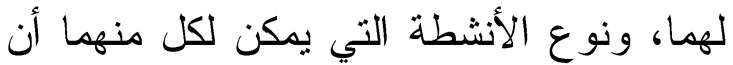

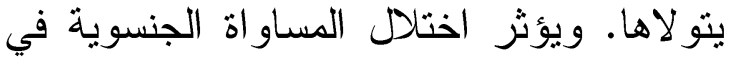
التعليم، و الحصول على مصادر الإنتاج الأخرى، و التوظيف، أو الكسب على علاقات القوة بين الرجل و المرأة، وبالتالي على قدرة كل منهما في التأثير على توزيع القوى بينهم، التها،

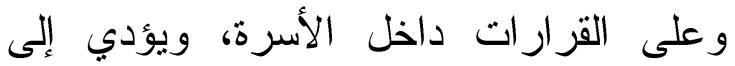
تباين في قدرات الرجل و المرأة على الاستفادة من الفرص الاجتماعية، و الاقتصادية، وذلك بالارتكاز على أسس توزيع القوى الاجتماعية

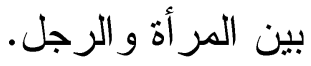

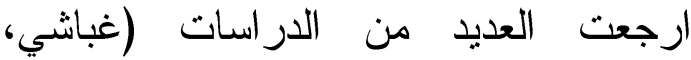

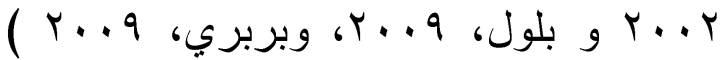
حالات الاقصاء التي تتعرض لها المرأة إلى بلى عوامل متتوعة ذات طابع اجتماعي في المقام الأول، ورغم اختلاف زوايا الرصد في تلك فئك

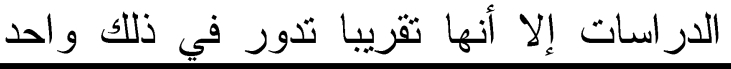


إن الهذف العام من هذه الدراسة هو

تحديد أهم مؤشرات اقصاء المرأة في مجتمع هله البحث، ويندرج تحت هذا الهدف العام مجموعة من الأهداف الفرعية على النحو

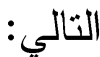

1-تحديد تعريف إجرائي لهصطلح إقصاء

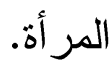

Y-تصديم مقياس قادر على بناء مؤشرات إقصاء المر أة في مجتمع البحث. r-التعرف على أهم مؤشرات إقصاء المرأة من الناحية الاجتماعية و الاقتصادية و السياسية و الثقافية في مجتمع البحث. ع- التعرف على دور متغيري الريف/ الحضر

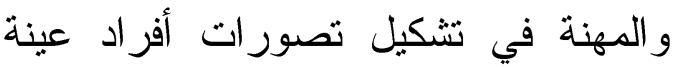
البحث لمؤشرات الإقصاء التي تعانى منها المر أة المهشة في مجتمع البحث.

ثانيا :الإطار النظري: 1- إسطلحات الدراسة :

\section{Exclusion أ. مصطلح الإقصاء}

التعريف اللغوي: الإقصاء في اللغة

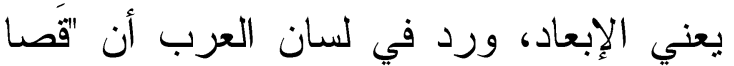

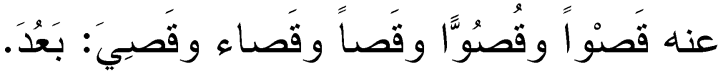

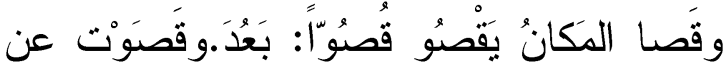
القوم: تباعدت. (ابن منظور، د ت)، وفي القدان

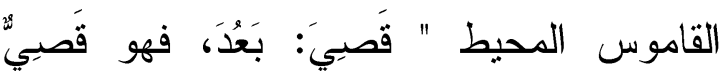

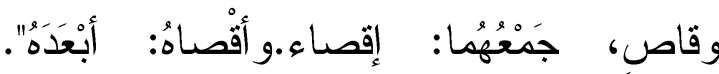

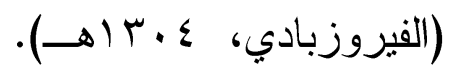

ويعد الباحث الفرنسي رينيه لينوير "

Rene Lenoir

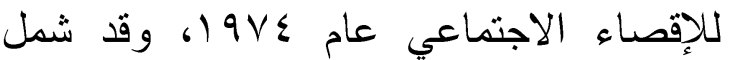

إقصاء المر أة، فالثقافة على اختلاف مكوناتها، تعمل على تشكيل خطاب حياة تقصى فيه المرأة، وتبتعد بها نحو زاوية تقليدية، تسند إليها مهام وأدوار مؤسسة على النظرة التقليدية للمر أة، وعلى التفرقة الثقافية بين الجنسين، وفقاً لمنظور النوع الاجتماعي. و إذا كان ثمة إجماع أو اتفاق بين

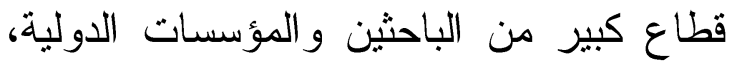

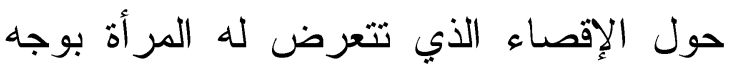

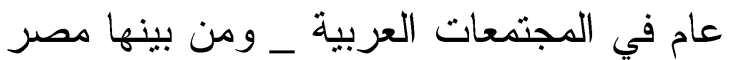

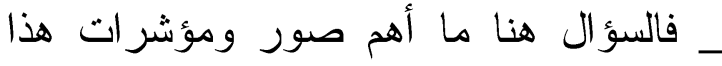

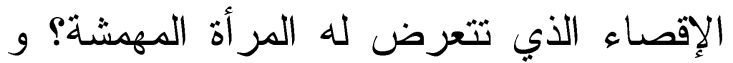
يمثل هذا السؤال موضوع البحث الراهن، و إجراءً يهدف إلى التحديد ، فإن الداسة التهات الر اهنة تسعى إلى الإجابة عن أربعة تساؤلات التان أساسية هي: - ما أهم مؤشرات الإقصاء الاجتماعي للمرأة

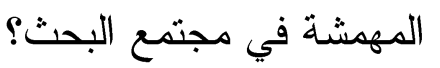
- ما أهم مؤشرات الإقصاء الاقتصادي للمرأة المهشة في مجتمع البحث؟ مؤن الأهاء - ما أهم مؤشرات الإقصاء السياسي للمرأة الهئه

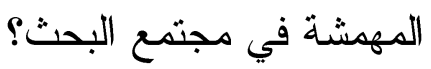

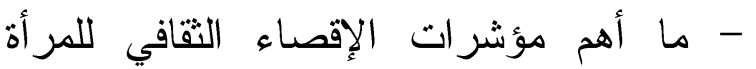
المهشة في مجتمع البحث؟ - هل هناك فروق بين تقديرات أفراد عينة البحث لمؤشر ات إقصاء المر أة المهشة تعود إلى متغيري محل السكن (ريف/حضر) و المهنة؟

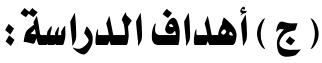


قادرين على تحقيق طموحاتهم الثخصية أو طموحات القريبين منهم، وبين أولئك الذين يختارون الابتعاد طواعية و بإرادتهم.

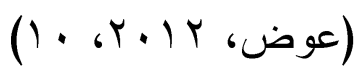

\section{التعريف الاجرائي لإقصاء المرأة المهمشة:}

و على ذلك، فإن الإقصاء يشير إلى منطلقات أساسية تحد من قدرة المرأة على تلتمية الإكاه إمكانيتها، وقدرتها على صنع و اتخاذ العديد من القرارات الذاتية المؤثرة على حياتها في الجوانب الاجتماعية والاقتصادية و والسياسية و الثقافية نتيجة للرواسب الاجتماعية، و الثقافية،

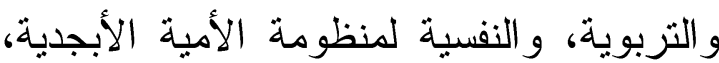
و المعرفية، و الوظيفية التي تحول دون تمكينها على المستوى الذاتي و المجتمعي.

\section{ب. مصطلح المرأة المهمثة}

ورد في معجم المعاني أن كلمة (تهميش)

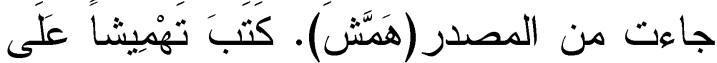

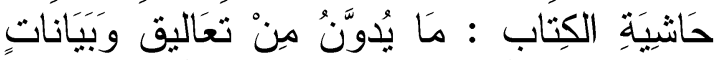

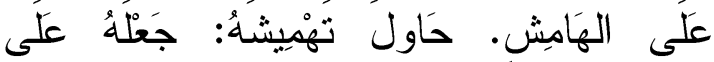

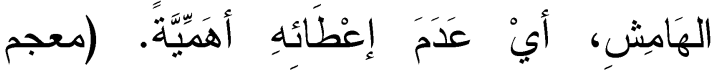

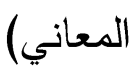

وقد أثار محسن عوض إلى أن التهميش

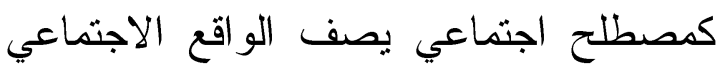

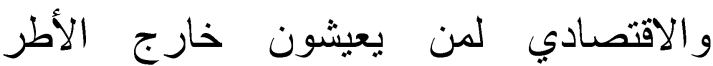
الاجتماعية التقليدية، ورغم أن ممارسات الإقصاء نحو الأفراد و الجماعات و المناطق يعود إلى بداية الزمن، فإن المصطلح لم يبرز

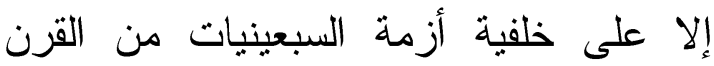
الماضي حيث وفرت التحولات الاقتصادية والاجتماعية والثقافية الناتجة عن الأزمة
تعريفه آنذالك · ا في المائة من سكان فرنسا،

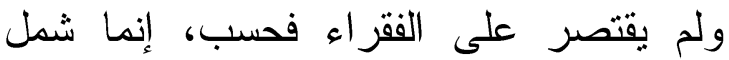
فئات مهشة أخرى، منها: ذو الإعاقة، و المسنون، والأطفال المعرضون للاستغلال،

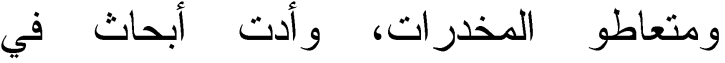
الثمانينيات والتسعينيات إلى توسيع نطاق تعريف الإقصاء الاجتماعي و إبعاده، ورأى إنى

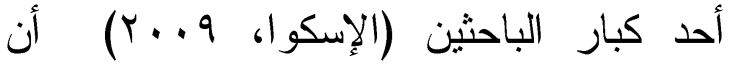
يشمل دفهوم إقصاء الأفراد، أو المجموعات عو امل مثل: مصدر الرزق، و العمالة الدائمة،

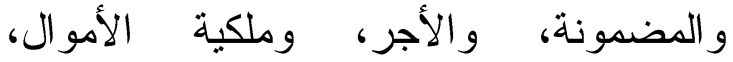

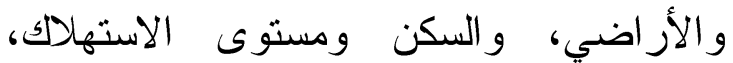
و التعليم، ومستوى المهارات، ورأس المال الآل التقافي. وقد عرفت اللجنة الاقتصادية و الاجتماعية لغرب آسيا (الإسكوا، 9 9..ب) الإقصاء الاجتماعي بأنه عملية استبعاد جزئي كامل، لأفراد، أو مجموعات عن المشاركة

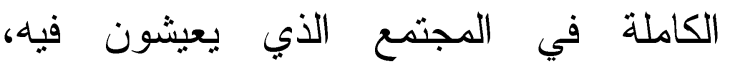

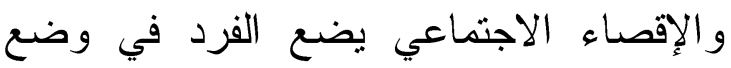
إجحاف مقارنة بغيره من الأفراد، فيؤدي إلى فئى المساس بحقوق هذا الفرد الاجتماعية، و الاقتصادية، و السياسية، ويضعف قدرنه على الإنى الحصول على السلع و الخدمات. ويقترب دفهوم الإقصاء كثيرا من مفهوم التهميش الذي يصف الواقع الاجتماعي

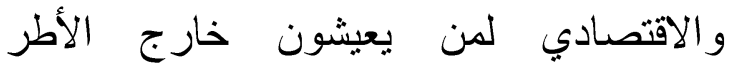
الاجتماعية التقليدية ، ويجدر هنا التتويه إلى لى الطي أهمية التفرقة بين فائت المهمشين بين أولئك الذين يختارون الانسحاب من التيار الرئيسي

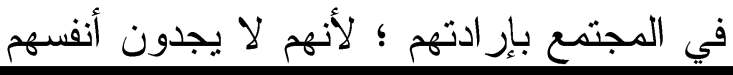


) هو نوع من التهميش، فهناك نحو 1 (1\%من

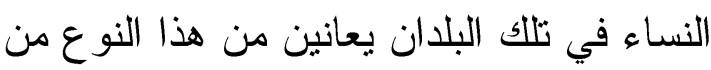

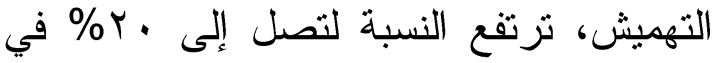

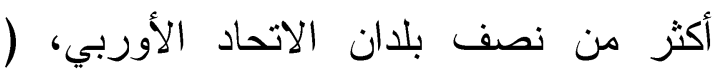
إيطاليا، فرنسا، لوكسمبورغ، النمسا، أيرلندا،

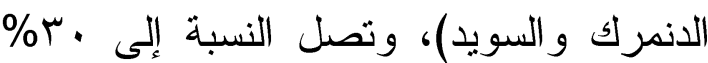
في ألمانيا، و \%00 في هولندا.

(Tijdens,2010,2 )

وفي الهند يأخذ مفهوم تهيش المرأة

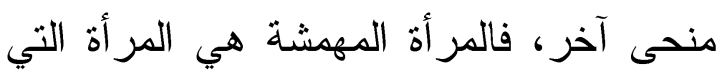
تحرم من مصادر القوة الاقتصادية، حيث تعاني من انخفاض معدلات مشاركتها في العمل، وتركزها في قطاعات العمل ذات الدخل المنخفض وغير الرسمي في الغالب، ويتخذ تهميش النساء صورا أخرى من خلال

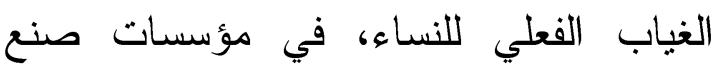
القرار الإداري و السياسي في الدولة. (Sadhna,2010,3)

وقد وسع البعض من رؤيته لـفهوم

تهيش النساء ، حيث يشير ساليز روبرت Salais, Robert

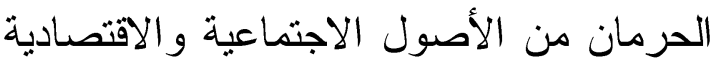
الأساسية؛ مما يؤدي بهن إلى الحيلولة دون

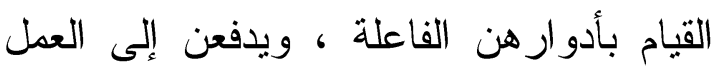

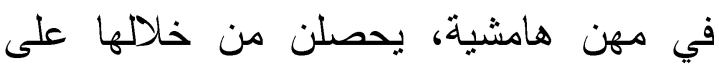

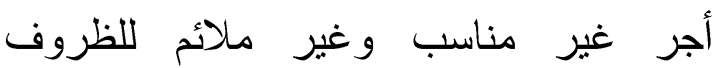
الاقتصادية التي تمر بها تلك الفئة والظروف

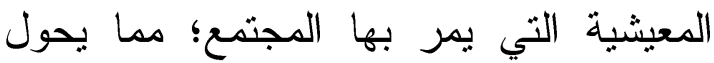
دون امتلاكهن القدرة على تبوء أية مكانة في لي لئي (Robert, 2007, 23).
الظروف لإجراء نقاش جديد للمعاني

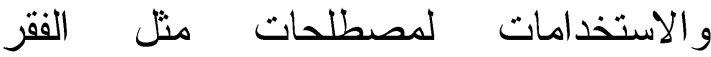

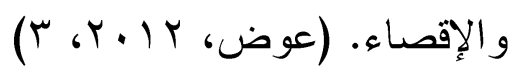

وعلى الرغم من الطبيعة الملتبسة لمصطلح التهميش كمفهوم فقد تم صقله تدريجيا و أظهر قدرة على تفسير تراكم عمليات لها أصولها تهات ف قلب السياسة و الاقتصاد و المجتمع، وتحديد المسافة بين الأفر اد و الجماعات و المجتمعات، في علاقتها مع مر اكز السلطة و الموارد و القيم

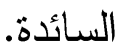

يعد اصطلاح المرأة المهيشة أحد أهم المصطلحات التي حازت على اهتمام العديد من المؤسسات الدولية المعنية بالثأن النسوي، وفي مقدمتها منظمات الأمم المتحدة، فتهميش النساء من وجهة نظر برنامج الأمم المتحدة

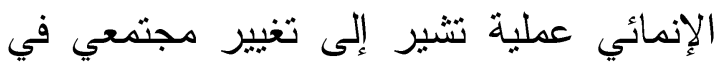
تعرض النساء لدرجة أثند من الحرمان من الإنيان اكتساب القدرات البشرية ومن توظيفها الفعال في مختلف مجالات النشاط البشري، وأيضا تمتل معاناتهن درجة أعلي من الحرمان من حقوق المواطنة ومن حقوق الإنسان عامة بالمقارنة بالرجال.( البرنامج الإنمائي للأمم

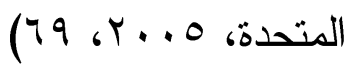
و الحقيقة أن وضع محددات نهائية لمؤشرات تهميش المرأة مسألة محل خلاف، فتلاك المؤشرات تتباين من مجتمع إلى آخر حسب الظروف والسياقات الاجتماعية و الاقتصادية لكل مجتمع، ففي بعض بلدان

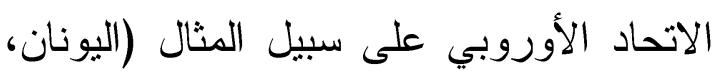

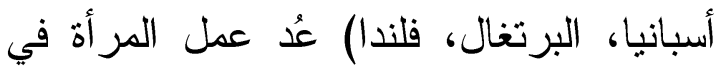
دوام جزئي ( أقل من · ب ساعة في الأسبوع 


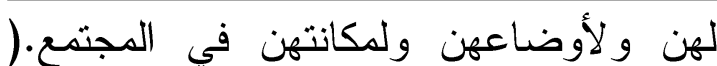

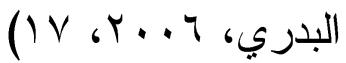

مفهوم المرأة المهثة إجرائيا :

ترى الباحثة أن المرأة المهشة هي شريحة من النساء يتم اســتبعادهن و إقصــائهن عــن قطاعات المجتمع على اختلافها (اجتماعيـا،

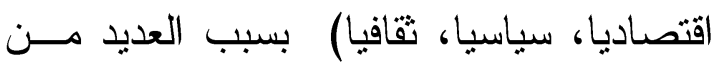

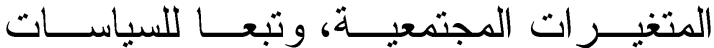
الاقتصادية و المتغير ات السياسية و الثقافية التي

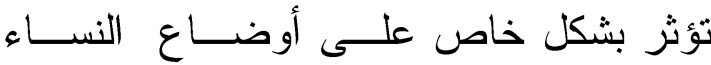
المستبعدات، و يتسمون بعدة سمات من أهمها:

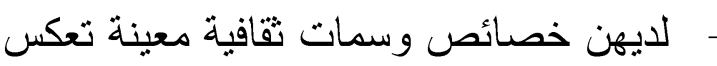
عدم قدرتهن على الاستفادة من مؤسسـات المجتمع الثقافية وتهميشهن ثقافيا. انتشار البطالة بينهن أو العمل في قطاعات

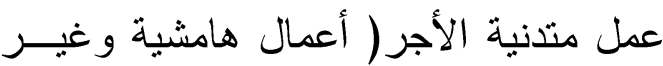

$$
\text { رسمية في الغالب ). }
$$

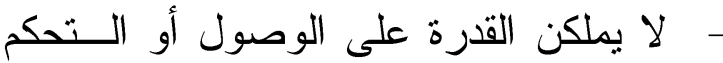
في الموارد الاقتصادية المتاحة لهن . لهن يتسمن بضعف ما يضفنه من قيمة اقتصادية

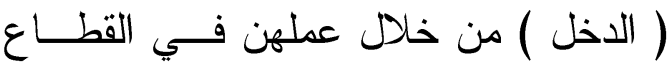

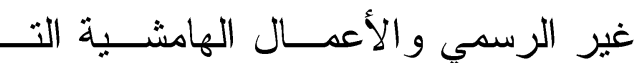
تلتاسب مع مؤ هلاتهن. - لا يستطعن الحصول على فرص التدريب

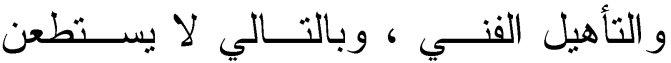
الحصول على فرص عمل ملائمة وأجور مناسبة .

ليس لايهن القدرة على اتخــاذ القـــرارات الخاصة بأدو ارهن في الأسرة و المجتمع.
وقد امتد الاهتمام بمفهوم تهميش النساء إلى الباحثين العرب، فقد عرفت "سحر بربري" تهميش المرأة بأنه مجموعة من إلن الأفعال و الاتجاهات الهدامة التي تحدث داخل

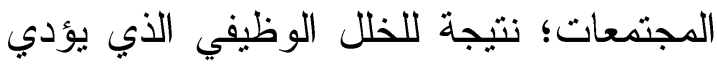

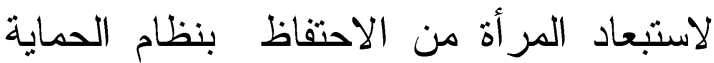

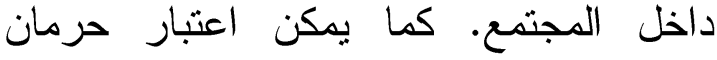
المر أة من الوصول للموارد التي تحتاجها مثل

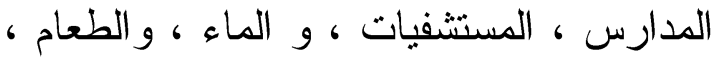

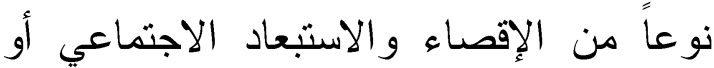

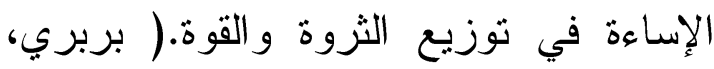
(I) Y r... 9

ونظر "عبد القادر علي" إلى تهميش النساء بوصفه مفهوما يعكس حالة الحرمان

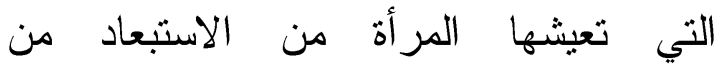

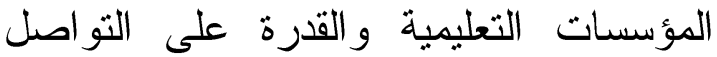

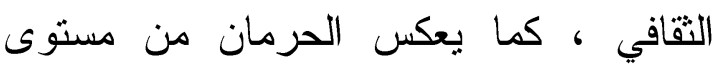

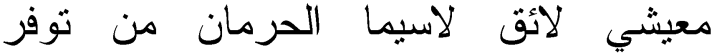

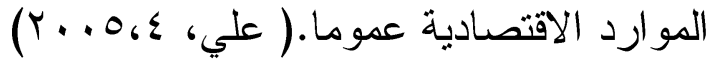

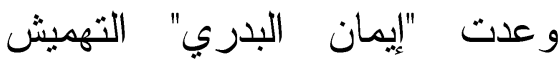
اصطلاحا يعبّر عن ايدلوجيا ومنظومة خاصة بالعديد من الفئات المهشة من الفقيرات، و المحرومات من الحصول على الخدمات الأساسية والاحتباجات الضرورية للمعيشة، و المحرومات من الخدمات التعليمية الملائمة لهن، و المحرومات من الحصول على خدمات صحية أولية وملائمة لهن و لأوضاعهن الهين

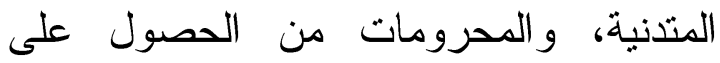
فرص اقتصادية تساعدهن على المعيشة ، و اللاتي يعانين من النظرة المجتمعية المتندية 
أساسي هو عنصر التمكـين (الاقتصـــادي السياسي - الاجتماعي) للمر أة.

ويعني التمكين تحقيق مسنوى عال مــن التحكم ؛ و إمكانية التعبيــر و الســماع لهـــا، و القدرة على التعريف والابتكار من منظـــور

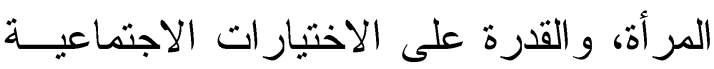
المؤثرة والتأثير في كل القرارات المجتمعية، وليس فقط فى المناطق الاجتماعية المقبولــــة

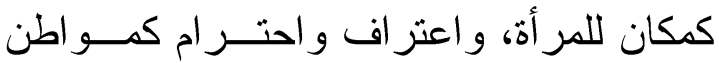
متساوٍ وكيان إنساني مع الآخــرين، و القــوة

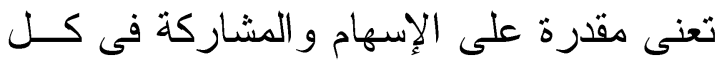
المستويات الاجتماعية، وليست فــى مجــرد الئه

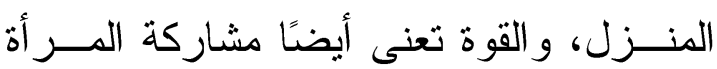

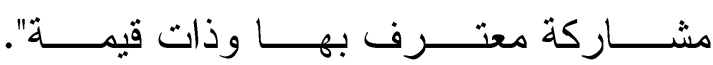
(Amin,2006)

" Broembsen " وقد عرف برومبسون تمكين المرأة بأنه: " تعزيز قدرات النساء للسيطرة على حياتهن، دن خلال جعل حقوق الإنسان و اقعية، خاصة بالنسبة للفقراء". "9roembsen,2007 : 9 ) ( "على ذات المعنى هيث عرفت تمكين المر أة بأنه: إتاحة الفرصة لمشاركتها الفاعلة في الحياة الاقتصادية، و السياسية، فضلاً عن تعزيز قدراتها على الاستفادة من التحصيل التعليمي و الصحة و الرفاه". ( Naz,2010 ) كما أشارت "أماني مسعود" إلى أن هنالك إبعاداً معينة يمكن الاتفاق عليها لتحديد مفهوم التمكين وهي: "أنه عملية اجتماعية متعددة الإبعاد، تتضدن إبعاداً نفسية و واقتصادية وسياسية، وتحدث على مستويات عدة: الفرد، و الجماعة، و المجتمع. وقد وبربط بين هذه
تدني أو انعدام العمل العام بشكل أساسي و العمل السياسي على وجه الخصــوص.

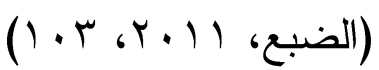

ج. مصطلح التمكين Empowerment

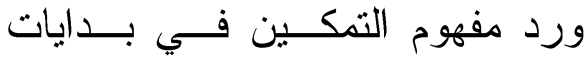

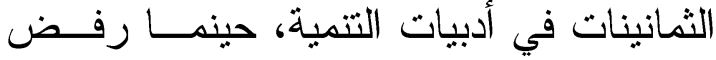
البعض أن تكون التنمية مجرد طاحونة في آلة تز اكم؛ لتحقيق النمو حتى على حساب الفقر اء ، ويرتبط مفهوم التمكين في أدبيات التتميــة باستقلالية المجتمعــات المحليــة و إعطائهــــا الفرصة للنهوض بأحو الها من خلال الاعتماد علي الذات

ويتصل مفهوم التمكـين بمفهــومي المشاركة و التتمية اتصالا وثيقاً، فقد أضحى لهي

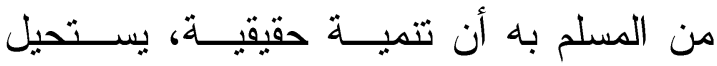
إنجازها على أي صعيد، دون مشاركة الناس به

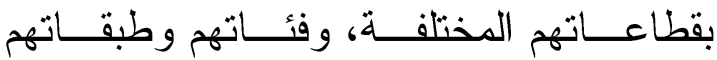
وشر ائحهم الاجتماعية، في صنعها من ناحية، وفي جني ثمار ها من ناحية أخرى. وقد حظي مفهــوم التمكــين باهنمـــام الكثير من المؤسسات المعنية بقضايا وشــئون

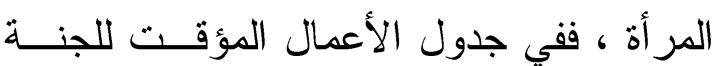

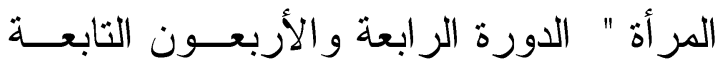

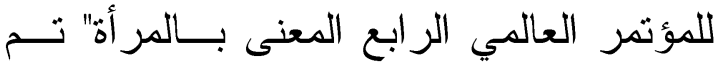

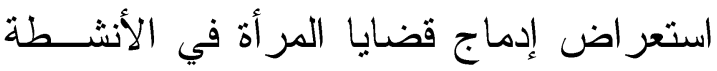
الرئيسية لمؤسسات منظومة الأمم المتحـــدة و اهو

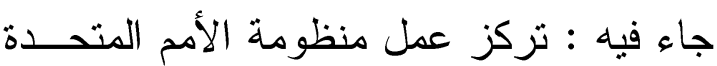

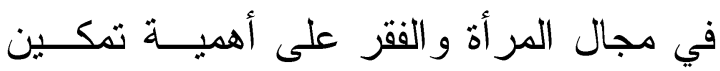
المر أة" ولكل مجال من المجالات هناك ثابـــ 
للقوة؛ ليصبح عنصر ا مشاركا بفعالية في شتى مجالات الحياة الاقتصادية و الاجتماعية، بمعنى امتلاكه القدرة على إحداث تغييز في الآخر قد يكون فرداً أو جماعة أو مجتمعاً بأكمله".(هيئة

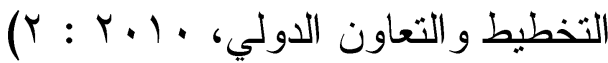
و لا يعنى التمكين تعزيز القدرات

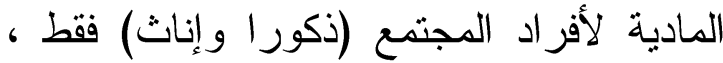
إنما بتضمن أيضا البعد المعنوي، ومفاده: "توضيح ورفع الوعي لاى النساء باللامساواة أو العنف أو التمييز الواقع عليهن ، ورفع استعدادهن وثقتهن بأنفسهن بأنهن قادرات على أداء جميع الأدوار ذات القيمة المجتمعية العليا ، سواء أكان في المجال السياسي أم التشريعي

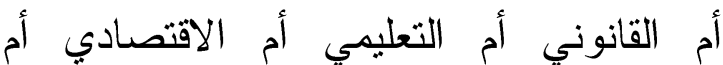
الصحي_ وأن قدراتهن يمكن إن أتيحت لها الفرص المتساوية و الموارد المتساوية أن ترثقي إلى نفس قدرات الرجال". (بدري، $(r: r \cdot)$

ويرتبط مفهوم التمكين في التحلــيلات السوسيولوجية الحديثة بمفهــومين آخـرين؛ تحقيق الذات أو حضور الذات ، وهو المفهوم الذي يشير إلى الوعي و المعرفة و الخبــرة أو ونو

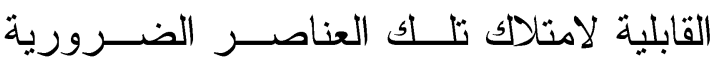
للمشاركة ومقاومة الضغوط الاجتماعبــة. إن المشاركة بهذا المعنى تشير إلى مدى القـدرة على الفعل وصنع الظروف ومقاومة الضغوط

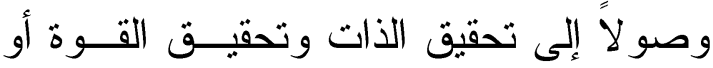
التمكن باز اء الظروف ذاتها. ومن هنا وبناء على تلك الآراء يمكن للباحثة القول بأن المر أة بصفة عامة و والمــر أة العربية بصفة خاصة ما تز ال تستشعر الكثير بـانه
المستويات فيكون تمكين الفرد جزءا من تمكين

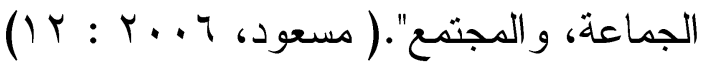
و أوضحت سلامي أن التمكين تعريف شامل يشير إلى عملية شمولية تبدأ بإدر الك المرأة ذاتها وشعور ها بالسيطرة على حياتها الخاصة وقدرتها على اتخاذ القرار، أما على المستوى الجماعي فهو قدرة النساء على المشاركة في عملية التتمية وخلق وعي مجتمعي بالحقوق الفردية و الجماعية، و القدرة على الانضمام إلى مجموعات ضغط وحركات اجتماعية قادرة على تمثيل مصالحهن، وتتتهي بتمنل أكثر للنساء في مراكز صنع القرار السياسي

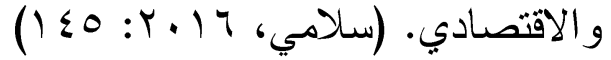
و التمكين بهذا المعنى هو المون المدخل الرئيس لتعزيز القدرات لدى أفر اد المجتمع، ذكوراً و إناثا، وهو المعنى الذي أكد عليه عندما رأى التمكين مجموعة "Kabeer"

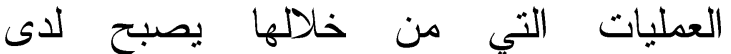
المستبعدين القدرة على صنع الخيارات التي ترتبط بثلاثة إبعاد لقياسها هي Choices

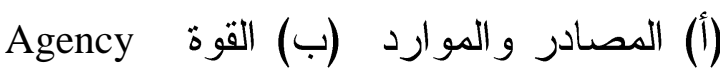

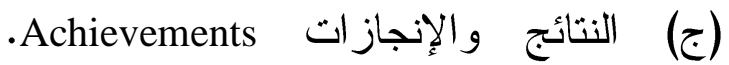

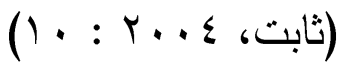

إذن مسألة امتلاك القدرات أو القوة تجسيد إجرائي لعملية التمكين، سواء أكان على مستوى الأفر اد أم على مستوى الجماعات، من هنا جاءت معظم البرامج الموجهة نحو تمكين المرأة على وجه الخصوص كترجمة إجرائية لهذا المنحى، فالخطة الوطنية لتمكين المر أة في سوريا، على سبيل المثال، انطلقت من مسلمة مفادها: أن التمكين "يقوم على امتلاك الفرد 
- ترسيخ البنية الأساسية لعلاقات القوة لدى المرأة، والتحكم في مؤثرات البيئة الاجنماعية التمكينية.

- المشاركة السياسية الفاعلة، بما بعزز ويعمل ترسيخ المصادر الاجتماعية للقوة، و الوعي

$$
\text { و القدرة عند المر أة. }
$$

r- السياقات المجتمعية المرتبطة بإقصاء

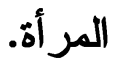

إن البحث فــي الســياقات المجتمعيــة المسؤولة عن صياغة وضعية للمــر أة التـي تعاني خلالها من شــتى صـــور الإقصـــاء ، يتطلب بداية التطرق للعو امـلـل الاجتماعبــة و الثقافية، وهنا يمكن القول بأن الأسرة تــأتي في مقدمة المؤسسات الاجتماعيــة المرتبطــــة

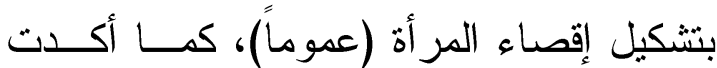
حنان الجريسي ، وذللك مـن خــلاءل "دعــم اتجاهات التفرقة وتحديد دور كل من البنـــ

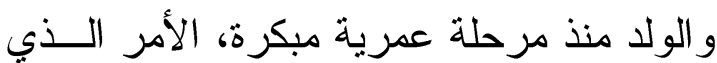

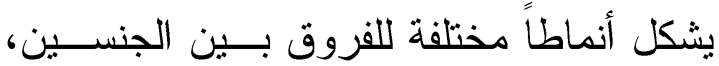

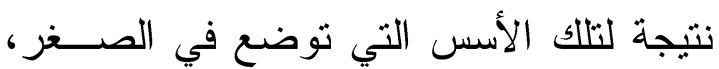
و التي يصعب تغيير ها في الكبر". (الجريسي،

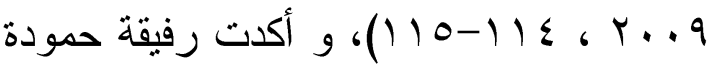
على المعنى ذاتة حين ركزت على الدور الذي

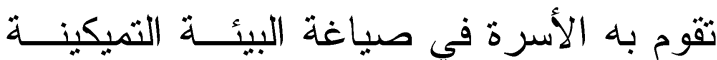
للمر أة، فالأسرة تقوم بدور مهم في تدعيم تلك

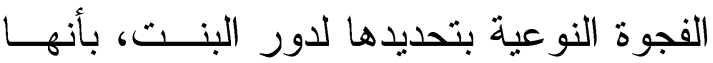

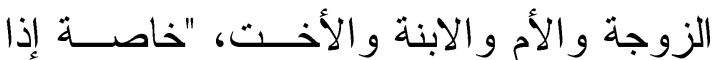

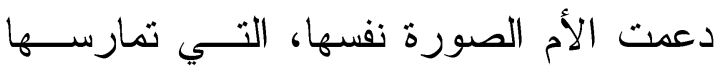
وتبثها لابنتها، وتحاول إقناعها بها، وتعلمهـا أن قدر اتها محدودة مقارنة بالذكر ؛ مما يجعلها

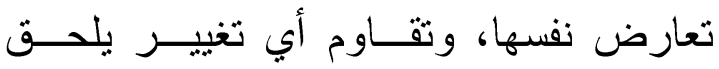

من الضغوط المؤسسية الاجتماعية التي تعوق تمكينها ـ إن مفهوم التمكين هنا يشير إلى كل ما من شأنه أن يطور مشاركة المر أة وينمــي من قدرتها وو عيها ومعرفتها ، ومن ثم تحقيق ذاتها على مختلــف الأصـــعدة الاقتصــــادية و الاجتماعية و السياسية، ويتيح لــديها كافــة القدر ات و الإمكانيات التي تجعلها قادرة علــى

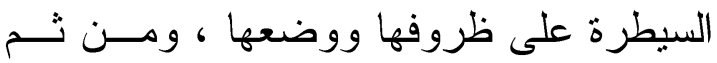
الإسهام الحر والواعي في بناء المجتمع على

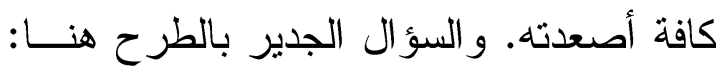
إلى أي مدى تثوافر للمرأة العربية على وجه العموم و المر أة المهيشة في المجتمع المصري لئري على وجه الخصوص، تلك المعطيــات التـي تحقق لها التمكين ، ومن ثم تكون معينا لهــا

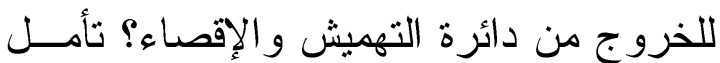
الباحثة الحصول على إجابة ذلك السؤال فــي نهاية البحث.

\section{المفهوم الإجرائي لتمكيز المرأة:}

بناء على الإسهامات السابقة في تعريف مصطلح التمكين، يمكن تعريف التمكين اجر ائيا بأنه تتمية مصادر القوة الاجتماعية و الاقتصادية و التقافية و السياسية لدى المرأة بشكل يجعلها قادرة على الآتي: - السيطرة و التحكم في إمكاناتها. - اتخاذ قر ار اتها الذاتبة، و الاجتماعية، بفاعلية، في كافة المجالات الحياتية، والأسرية،

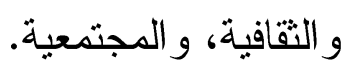
- - بناء الدور الاجتماعي الفعال للمر أة. 
المعرفية و التفسيرات السائدة، من هنا يمكن القول إن الثقافة لها دور أساسي في تشكيل رؤية المرأة لذاتها ودور ها في المجتمع، وفي نفس الوقت "تبرز الحاجة لعدم إعادة إنتاج

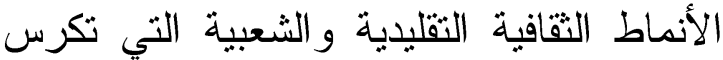
فقط الأدوار الثقليدية والتمايز النوعي خاصة

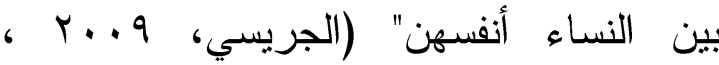
.(1) $\varepsilon$

وتعاني المرأة في ظل مثل هذه البيئة

الاجتماعية التقافية من حالة اغتر اب عن البنية

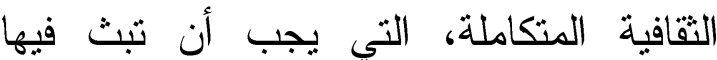
أصول القوة الاجتماعية، وتدعمها بإطار معرفي يجعلها على وعي بقدر اتها، و إمكانياتها

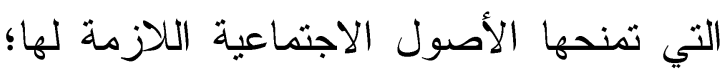

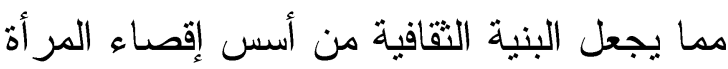

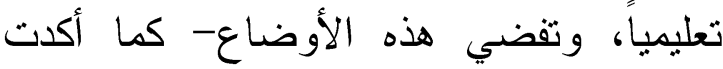

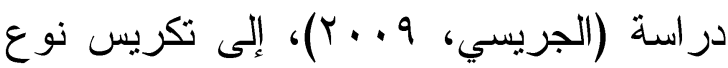
من العقلية الإنسانية، و الثخصية النسائية، الثي تتسم بسمات سيكولوجية كالسلبية و الانسحاب و الابتعاد عن المشاركة والرضا بالتبعية و الارتباط بالأدو ار التقليدية، و القيم الثتليدية". ويشكل العرف _الذي هو أحد المتغيرات

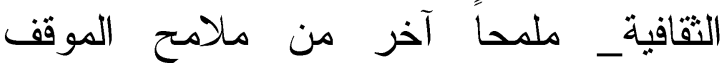
الاجتماعي، الذي تتشكل على ساحته عملية

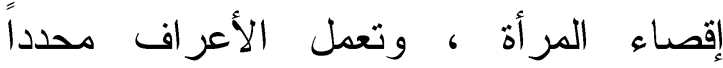

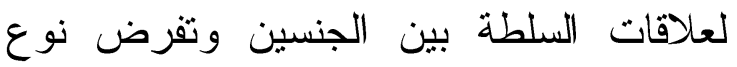
العمل الذي بعد مناسباً للرجل و المرأة، لهذا لهات فهي التي تشكل المحددات الاجتماعية و الاقتصادية للتعليم لدى الفتاة و الفتى، وبشكل

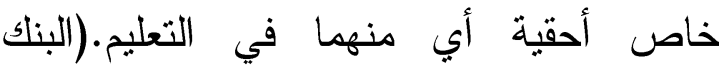

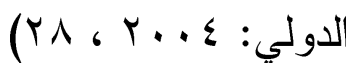

بأدو ارها في مؤسسات التنشــئة الاجتماعيــة

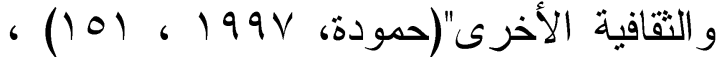

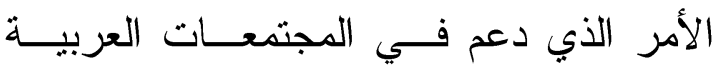
_وبخاصة المجتمع المصري_ أن رؤية تعليم

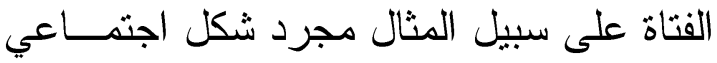
يساعدها على القيام بأدو ارها التقليدية، بخلاف الولد الذي يمثل تعليمه لأعلى المر احل هــــا

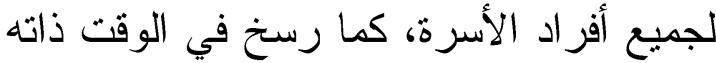

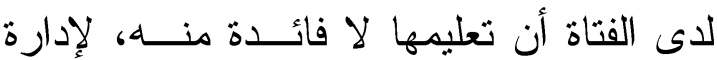
شؤونها المنزلية، وتربية الأطفال، وأن قيامها بأدوار أخرى ليس له من الأهمية ما لأدوارها

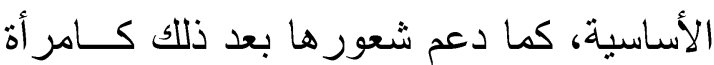

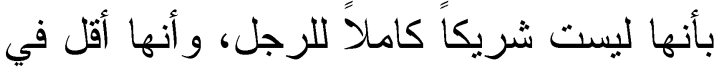
دور ها منه، و أنه ليس من حقها أن يكون لديها إطار معرفي مجتمعي متكامل عن ذاتها وعن مجتمعها بشكل يساعدها على إدارة منظومسـة

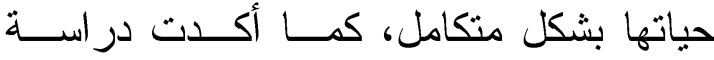

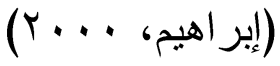

ويمثل المتغير الثقافي العنصر الحاسم

الثاني في عملية تشكيل إقصاء المرأة ، هذا المتغير لا يمكن النظر إليه بوصفه عنصرا

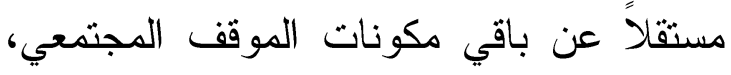
فهو متغير متداخل، ومتشعب في علاقاته مع التافي كافة المتغيرات الأخرى كالأسرة و التربية و الإعلام، لكن الباحث هنا _ ولغرض التحليل

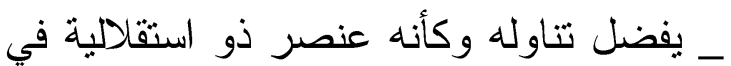
علاقته بالإقصاء.

وتمثل الثقافة كما يشير (بينيريا

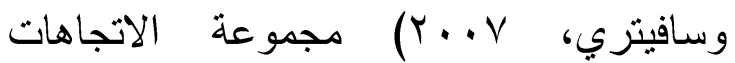
و الأنماط والأطر التي تتبثق عنها وتتبلور نتيجة لها المعتقدات و القيم و المتل و البنى 
طبيعة العلاقات بينهما إلا في أوساط محددة.

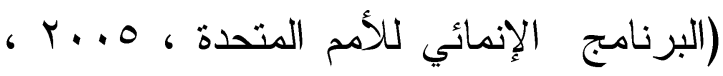
• 1 (1)، الأمر الذي عكس قيماً ثقافية سلبية على مكانة المر أة في إطار قيم النظام الأبوي، الذي يدعم تفوق الذكر، وتثبيت هيمنته على

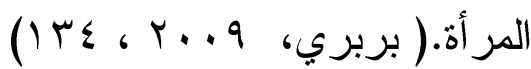
إن المحصلة النهائية لكل تلك التحليلات، أن بنية المجتمعات العربية ومن بينها المجنمع المصري، تعمل على تأكيد عملية إقصاء المرأة، فالبيئة المجتمعية تعمل على تشكيل خطاب حياة تقصى فيه المر أة على وجه العموم ، ويزداد الأمر إقصاءً بالنسبة للنساء المهشات، وتبتعد بها نحو زاوية تقليدية وتسند إليها مهام وأدوار مؤسسة على النظرة التقليدية للمرأة، وعلى التفرقة الثقافية بين ولين الجنسين، وفقاً لمنظور النوع الاجتماعي، وهذا ما رصدته در اسة ماهر الضبع و التي أوضحت أن هناك أكثر من أربعين مؤشراً دالة على رهئ تهميش النساء ، ومن ثم اقصاؤهن عن الحياة المجتمعية، و قد تتوعت تلك المؤشرات ما بين اجتماعية و اقتصادية وثقافية ونفسية وبيئية

$$
\text { وصحية. (الضبع، (1) }
$$

وتشكل العوامل الاقتصادية الملمح

الثاني الذي تتشكل من خلاله عملية الإقصاء، بالنسبة للكثير من الدر اسات و التقارير الدولية، ويأتي الفقر في مقدمة هذه العوامل، يؤكد

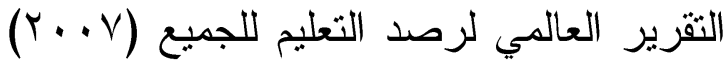
"أن الأوضاع المادية للأسرة تؤثز في كل مكان تأثيراً كبيراً على الالتحاق و تعرض شرائح بعينها من تللك الأسر وخاصة النساء
ويرى ( نبيل حافظ و آخرون، د ت)

أنه في العديد من المجتمعات، عادة ما يتحدد دور المرأة بناء على أدوارها النوعية التي هي تجعلها تتخذ مسار ات اجتماعية عدة، تسهم في تحديد ذاتها وكيانها المجتمعي، تبعاً لبيئة اجتماعية، ووسط ثقافي له تقالبده، وأهدافه، وفلسفته، وقوانينه التي تثشى مع ثقافة المجتمع و أهد افة وفلسفته .

وقد ترتب على كل تلك الأوضاع أن وان أصبحت المر أة محاصرة ثقافيا، الأمر الذي حد من أدوار المرأة، وجعلها حبيسة الأدوار التقليدية التي تتمثل في الإنجاب ورعاية الأسرة و الشؤون المنزلية ورؤية خروجها، واختلاطها مسألة فساد أخلاقي رغم دخولها المجال الاقتصادي، و السياسي و الثقافي، كما

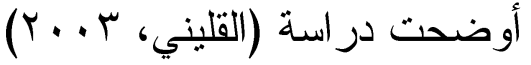
وفي السياق ذاته تؤكد (غباشي،

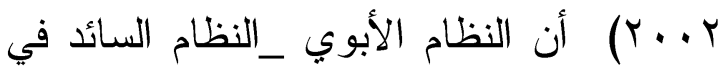
كافة المجتمعات العربية_ هو الذي يحدد أهم أسس السلطة في اتخاذ القرارات الاجتماعية و الاقتصادية و الثقافية و التعليمية للمر أة، كما يحدد مساحة خاصة للمر أة، ويربط بين هويتها الاجتماعية من جهة، وارتباطها باسم رجل

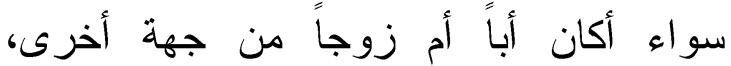
وبالتالي تحدد قيمتها الأساسية كإنسان. وبالرغم من حدوث تغيرات دخلت على الإطار التسلطي الحاكم علاقة الرجل بالمرأة، وأحدثث به تطوراً جذرياً، فإنه لا لإنه يمكن القول إن تلك التطورات مست الطابع الوظيفي للعلاقة التسلطية بين الجنسين في العمق، كما أنها لم تحدث تغييراً نوعياً في 


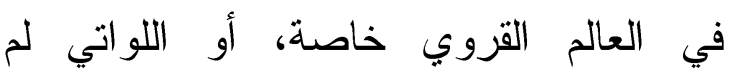

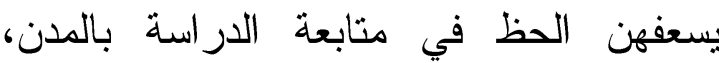
يعشن على الهامش، كما أكدت دراسة حدئة الهيثة صادرة عن مركز بروكنجز أن المرأة الريفية

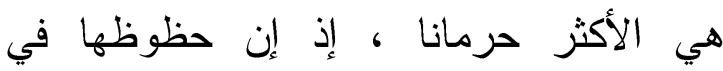
الحصول على عمل في القطاع الرسمي أقل إن الن بالمقارنة مع المرأة التي تعيش في الدئ

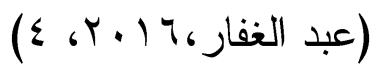

من هنا يمكن القول إن الإقصاء مسألة تميل للتركز في الدناطق الريفية، وربما يكون هذا سبباً وجيهاً لتوجه الباحثة نحو إجراء

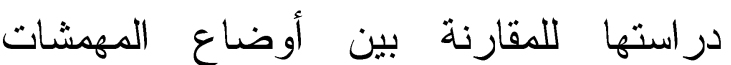
المقصيات في مجتمعين أحدهما ريفي والآخر الرضاع حضري.

و إلى جلى جانب كل من العوامل الاجتماعية و التقافية ومتغير الريف و الحضر في صباغة الإطار المجتمى الذي تتشكل خلاله عملية إقصاء النساء، فإن العامل العلائل الإعلامي لا يقل أهمية عن تلك المتغيرات، فالمؤسسة الإعلامية إحدى أهم وسائط التنشئة الاجتماعية التي تضطلع بدور تربوي وتعليمي

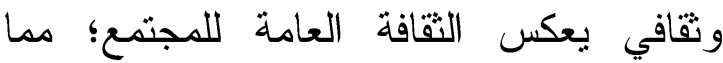
يميزها بالتتوع عن أية مؤسسة أخرى؛ لأنها تتميز بالجاذبية، و تشغل تستهلك وقتاً أطول ، وتتيح مخاطبة كل المستويات و الثقافات. (حافظ

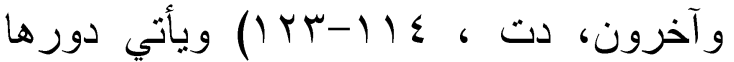
ــيما يتعلق بالمرأة_ موازياً للاور الذي تقوم

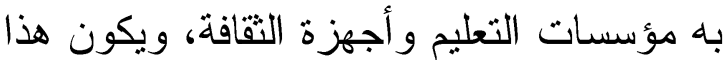
الدور إما نمطياً مصاغاً وفق قو الب جاهزة لتكرس الوظيفة التقليدية للمر أة، التي لا يشغلها

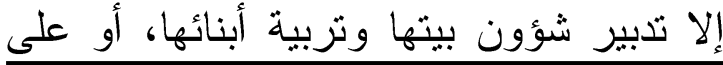

للإقصاء الاجتماعي وفي كثير من أوجه

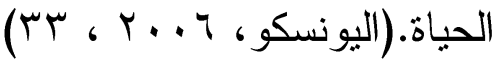
ويمتد أثز العوامل الاقتصادية التي يتصدرها الفقر في إقصاء الفتيات إلى مسالة

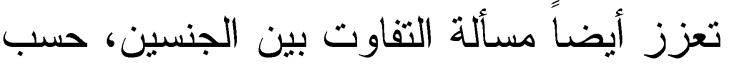

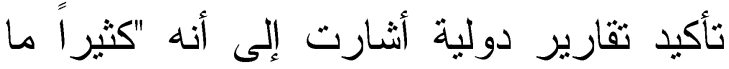
تتشأ أوجه التفاوت بين الجنسين، ومن ضمن هذه العقبات عقبة الفقر، وما يلازمه من

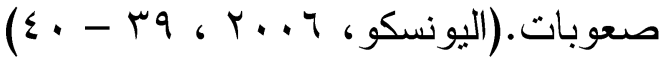
من ذلك يمكن القول بأن العامل الاقتصادي يمثل قاطرة الجر بالنسبة لمسألة الإقصاء بوجه عام، وهو الأمر الذي دفع بأحد

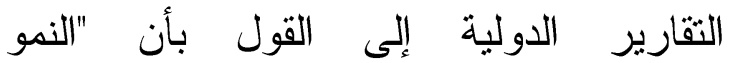
الاقتصادي المطرد و الحد من الفقر يؤديان إلى الى الى إمكانية تو افر المزيد من الموارد الحكومية

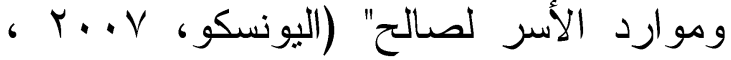

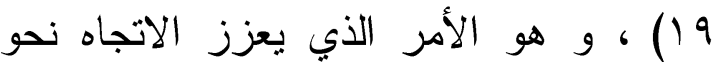
التمكين بوصفه الوجه الآخر للإقصاء. ويعد متغير الريف/ الحضر متغيرا فاعلا في تشكيل حالة الإقصاء التي تتعرض لها التها

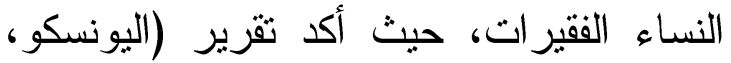

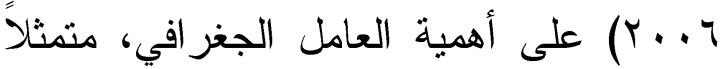
في التوزيع بين الريف و الحضر، في مسألة التهاء

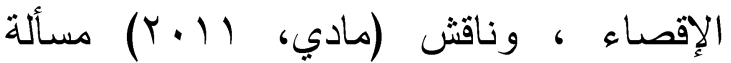
إقصاء النساء ، و أثشار إلى أنه يمكن القول القاءل بأن المتضررين في هذا المجال هن الفتيات، ويرجع ذللك إلى أسباب مختلفة ذات طبيعة هينة اقتصادية، أو اجتماعية، أو ثقافية، وفي كثير من الأحيان تجتمع كل هذه الأسباب لتتكل

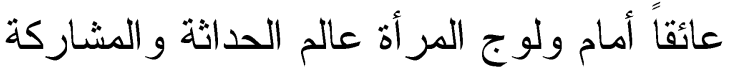
في التنمية وفي اتخاذ القرار؛ مما يجعل النساء 
وصف المؤشرات الدالة على إقصاء المر أة المهشة في مجتمع البحث. ب. استخدمت الباحثة المنهج المقارن وذللك الكئك لتحليل وتبيين مدى اختلاف مؤشرات

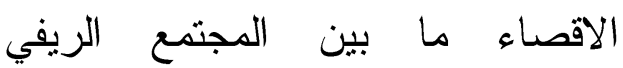
و المجتمع الحضري.

r- أداة جمع البيانات: اعتمدت الدراسة بشكل أساسي على أداة رئيسة هي "مقياس إقصاء

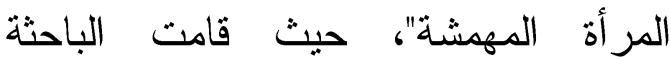
بتصميم هذا المقياس ومرت عملية التصميم

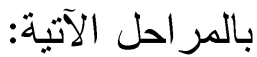

الخطوة الأولى : تحديد مؤشر ات إجر ائية لإقصاء

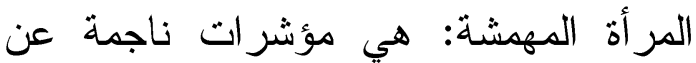
إقصاء المرأة المهشة المرتبطة بالحرمان من الأصول الاجتماعية والاقتصادية و الثقافية و السياسية على النحو الآتي: أ. الإقصاء الاجتماعي، ومن مؤشراته: ضعف الدور داخل الأسرة، وعدم إمكانية

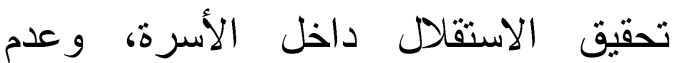
القدرة على تحمل الضغوط الاجتماعبة، وعدم الاعنداد بالرأي في مسائل الارتباط و الزواج، و ضعف المشاركة في اتخاذ

$$
\text { القرارات الأسرية. }
$$

ب. الإقصاء الاقتصادي، ومن مؤشراته: ضعف الإمكانيات المؤهلة للعمل الملائم، و الاشتغال بالأعمال الهامشية، وعدم كفاية الدخل للوفاء بالاحتباجات، وعدم القدرة على الششاركة في اتخاذ القرارات الاقتصادية للأسرة، وعدم الشعور بالأمان الوظيفي.
النقيض لهذا الدور النمطي، يقوم بإثاعة صورة إمر أة جديدة، مساوية للرجل، وموازية له في قوة الحضور المجتمعي، وفاعلية التأثير السياسي و والاقتصادي و الثقافي.(الهرقام، (AV , Y... r

ويشير (عصفور، r...r) إلى أن الدور السلبي للإعلام عادة ما يتعدى الدور

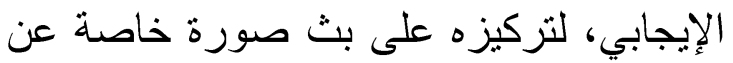
المر أة تتسم بالسلبية، تسهم في تثبيت الصورة لإنى السائدة عن المرأة التابعة و إثاعتها ، سواء لأهاء في أذهان الرجال الذين تربوا ثقافياً و إعلامياً على أنهم الأقوى والأقوم، أو في أذهان النساء اللائي لا يزلن خاضعات للأيدلوجية المجتمعية السائدة عن المر أة التابعة.

\section{ثالثا : الإجراءات المنهجية لللارسة ؛}

1- أسلوب البحث ومنهجه: تقع الدراسة الحالية تحت مظلة الدراسات الوصفية التحليلية، ومن ثم فقد اعتمدت الدراسة وبشكل أساسي على كل من منهج المسح الاجتماعي بالعينة، والمنهج الوصفي المقارن وذلك على النحو التالي:

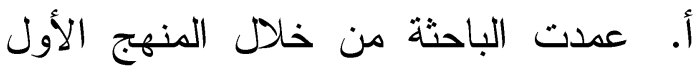
إلى سحب عينة من المجتمع الأصلي، حاولت أن تكون ممثلة لمجتمي البحث قدر الإمكان؛ وذلك لوصف المؤشرات المختلفة للإقصاء الذي تتعرض لهان اله المرأة في كلا المجتمعين، و على ذلك للكاء لأل فإن استخدام الباحثة للمسح يمكن ثبريره من خلال طبيعة الموضوع الذي احتاج إلى منهج من شأنه أن يمكن الباحثة من طن الني 
يعني إمكانية الثقة في صدق الأداة في القيام

بقياس ما سعت إلى قياسه. ج. عدق الاتساق الداخلي توضح بيانات الجدول التالي معاملات صدق الاتساق الداخلي بين إبعاد المقياس الفرعية: جدول (1) يوضح معاملات صدق الاتساق الاخلي بين إبعاد المقياس الفرعية و المقياس

\begin{tabular}{|c|c|c|c|c|}
\hline \multicolumn{5}{|c|}{ الكلي } \\
\hline الرابع & الثالث & الثاني & الأول & الإبعاد \\
\hline & & & & الأول \\
\hline & & & $.0 \mathrm{VA}$ & الثاني \\
\hline & &.$\leqslant \vee \vee 0$ & .710 & الثالث \\
\hline & سYOK. & . . $2 \wedge \mu$ & . & الر ابع \\
\hline
\end{tabular}

باستخدام الاختبار الاحصائي بيرسون توضح بيانات الجدول السابق أن معاملات الارتباط بين أبعاد المقياس الفرعية، كانت دالة عند مستوى (1 ...)، وهو ما بعني أن المقياس يتمتع بدرجة عالية من الصدق. الخطوة الرابع : ثبات المقيساس :

قامت الباحثة بتطبيق مقياس إقصاء المرأة على عينة قوامها . ب امرأة ثم أعاد التطبيق على العينة نفسها في المرة الثانية، ويوضح الجدول التالي معامل ثبات الإعادة بين عمليتي

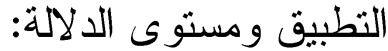

جدول (Y) ثبات مقياس إقصاء المر أة المهمشة بطريقة ثبات الإعادة باستخدام اختبار ألفا كرونباخ

|(*) ملحق التحليل العاملي رقم
ت. الإقصاء السياسي، ومن مؤشراته: ضعف المشاركة في الانتخابات، و عدم القدرة على ممارسة العمل السياسي، و عدم القدرة على القي المشاركة في العمل الأهلي، وضعف لئف الوعي بالعمل السياسي وأهميته، وضعف الوعي بالحقوق السياسية للمر أة. ث. الإقصاء الثقافي، ومن مؤشراته: عدم المساواة بالذكور في التعليم، و ت تحديد تخصصات معينة للنساء عدم مواصلة التعليم ضعف المشاركة في العمل الثقافي العام.

الخطوة الثانية: المقياس في صورته المبئية: بعد الاطلاع على التزاث النظري العربي و الأجنبي، صيغ في شكله الأولي، وجاء في

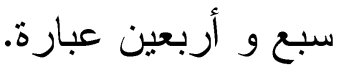
الخطوة الثالثة : صلدق المثياس : أ. . صدق المحتوى (الصدق الظاهري): قامت الباحثة بعرض المقياس في شكله الأولي على خمسة محكمين من ذوي الاختصاص، وقد أسفرت عملية التحكيم عن أن العبارات التي كانت نسبة اتفاق المحكمين على أنها تقيس ما يشير إليه المقياس .99\% فأكثر بلغت ، ع عبارة فقط، وتم استبعاد V عبار ات بناء على عدم اتفاق المحكمين عليها، حيث بلغت نسبة عدم الاتفاق أقل من . 9\% . ب. صدق التحليل العاملي: أوضحت نتائج التحليل العاملي "باستخدام تدور المحاور المتعامد" أن جميع إبعاد المقياس و البالغة . ع عبارة، كانت درجة تشبعاتها عالية، إذ جاءت درجات تشبعاتها أكثر من اء.. وهو ما 
وقد اعتمدت الباحثة على حساب الوسط الحسابي (الوسط المرجح) (Weighted Mean) وتحدد الاتجاه (Attitude) على القيم الآتية :

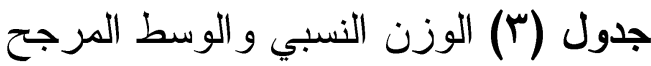
لعبار ات مقياس إقصاء المر أة المهمشة المشئ

\begin{tabular}{|c|c|c|c|}
\hline الوزن النسبي & المستوى & الرأي & المرجح \\
\hline منخفض & أرفض & $\gamma$ & من ا الى \\
\hline للغاية & بشدة & مطلقاً & 1.19 \\
\hline منذفض & أرفض & لا & من .1.1. \\
\hline متوسط & محسـايد & أحيانًا & 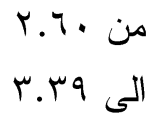 \\
\hline مرتفع & أو افق & غالباً & 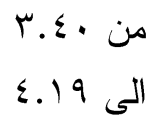 \\
\hline مرتفع للغاية & بثدة أو افق & بكثرة & 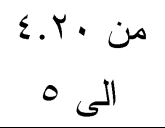 \\
\hline
\end{tabular}

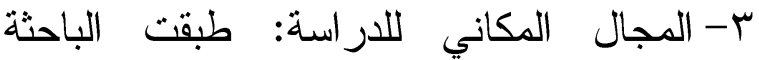
دراستها الميدانية على كل من قرية كفر طناح و هى إحدى القرى التابعة لمركز المنصورة ، فضلا عن مدينة المنصورة ، و الفئ

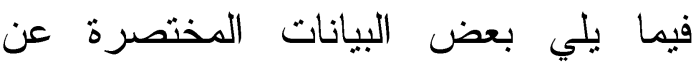
مجتمعي الدر اسة : ماسل

قرية كفر طناح : تقع على الضفة الجنوبية

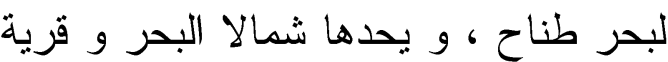

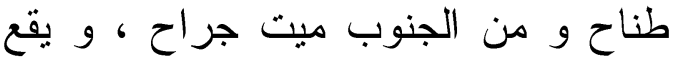
شرق القرية قرية التتسيمية ، و من ناحية الغرب قرية كوم بني مر اس • و هي و احدة من أقدم القرى في محافظة الدقهلية،وكانت تعرف قديما باسم منية الصالحين تمييز الها

\begin{tabular}{|c|c|c|c|c|}
\hline الدلالة & لمعات & الالحيران & المتوسط & البعدياس البلاس \\
\hline$\ldots .1$ &. .19 & س. 0. & $09 . \varepsilon$ & الأول \\
\hline$\ldots 1$ &..$\Delta r$ & r.YY & $r . . v q$ & الثاني \\
\hline$\ldots 1$ &..$V Y$ & \&.Vq & Vr.r. & الثالث \\
\hline$\ldots 1$ & $\therefore .10$ & $r .99$ & OV.YY & الر ابع \\
\hline
\end{tabular}

باستخدام الاختبار الاحصائي ألفا كرونباخ

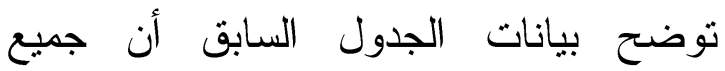
معاملات الارتباط بين عمليتي التطبيق الأولى لئى

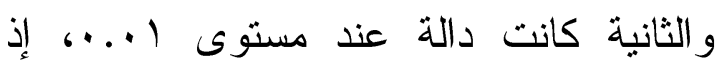
كانت معاملات الثبات على النحو الآتي:

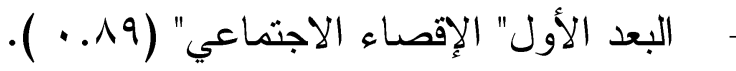

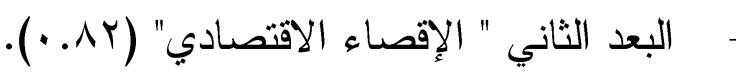

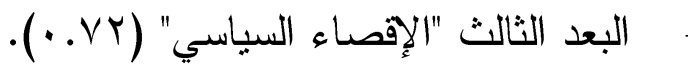

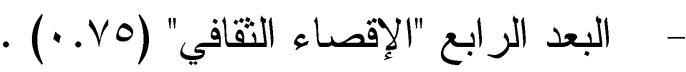

\section{الخطوة الخامسلة : المقياس في ثكله النهائي:}

بعد أن تأكدت الباحثة من تشبع عبار ات المقياس وصدقه وثباته، أصبح المقياس جاهزاً للنطبيق، ويتكون من ·ـ عبارة موزعة على أربعة إبعاد أساسية، فضلاً عن عدد من الأسئلة

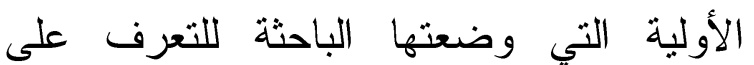

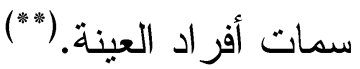

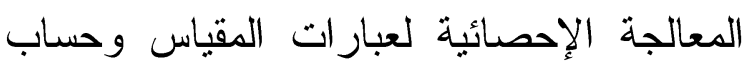
الوسط المرجح: اعتمدت الباحثة على نمط ليكارت الخماسي في

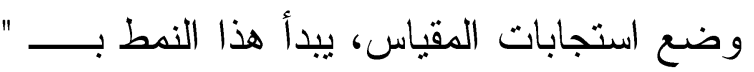

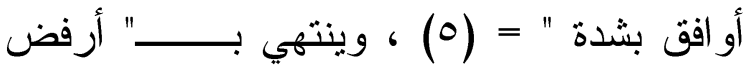
بشدة"( ). هذا مع الأخذ في الاعتبار عكس القيم في حالة الاستجابات السلبية. عن بعض القرى المجاورة التي كانت تضم 
r- تحديد درجة صدق المقياس المقتر ح ، وذلك باستخدام معامل الثبات و واختبار التحليل العاملي.

r-تحديد الوزن النسبي لمؤشرات الإقصاء في إبعادها الأربعة باستخدام المتوسط الحسابي والانحر اف المعياري.

ع-تحديد دلالة الفروق بين عينتي الريف و الحضر، فيما بتعلق بمؤشرات الإقصاء ،وذللك باستخدام الاختبار الإحصائي (ت). 0-تحديد دلالة التباين بين الفئات المتتوعة لأفر اد العينة حسب المهنة على إبعاد مقياس مؤشر ات إقصاء المر أة المهمشة. 0- عينة الدراسة وخصائصها: نظر اللظروف التي تميز أفر اد مجتمع البحث من عدم وجود بيانات تقصيلية ودقيقة حول حجم أفراد المجتمع وخصائصهم ، فقد لجأت الباحثة إلى أسلوب المعاينة العمدي، وقامت بتطبيق

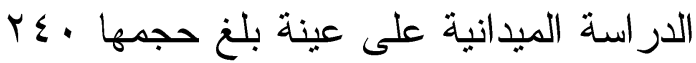
مفردة، وتقع ضمن نطاق العينات الغرضية، و قامت بسحب مفردات العينة وفقاً للطريقة الميسرة، من خلال التوجه إلى الأماكن التي أمكن الحصول من خلالها على مفردات العينة منل أماكن العمل و الأسواق و الوحدات الصحية، وفي بعض الأحيان تم التوجه مباشرة إلى بعض المنازل الو اقعة في نطاق مجتمع البحث، وقد انقسمت العينة إلى قسمين

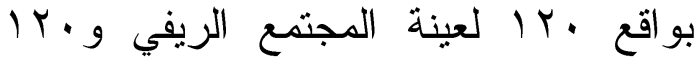
لعينة مجتمع الحضر • لمانع وقد جاءت خصائص عينة البحث على النحو
بعض اليهود، فكانت هذه التسمية التي ميزتها عن القرى الأخرى • و بيلغ عدد

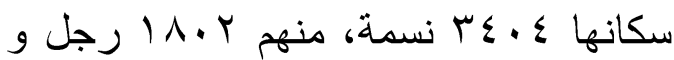

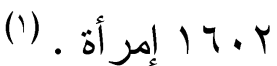
مدينة المنصورة : تقع المدينة على الضفة الشرقية لنهر النيل - فرع دمياط و يقابلها على الضفة الغربية مدينة طلخا. تبعد . كم إلى شمال شرق القاهرة .تتقم المنصورة إلي عدة وحدات محلية يضمها المجلس المحلي الشعبي لمدينة و مركز المنصورة و مقره ديوان عام المحافظة . يخص المدينة (البندر) منها عدد اثثين وحدة إدارية محلية لكل منها رئيس و عدد من رؤساء الإدارات .هما : هى شرق المنصورة و يختص بها قسم ثان شرطة المنصورة هى غرب المنصورة و يختص بها قسم أول شرطة المنصورة. (r) ع- خطة التحليل الاحصائي للبيانات: اعتمدت الباحثة على برنامج حزمة البرامج الاحصائية للعلوم الاجتماعية ( Spss)، وقد وضعت الباحثة خطة التحليل الإحصائي

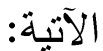

1-تحديد درجة الصدق والاتساق الداخلي للمقياس المقترح، وذللك باستخدام معامل الارتباط.

(1)(الجهاز المركزي للتعبئة العامة و الإحصاء (T 1 (Y) ، البيانات السكانية للمدن و القرى ، ص لـ 170

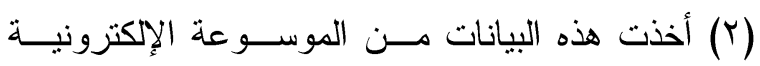




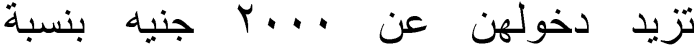
$\%$ \%.r

ث. - تلتوزع عينة الدراسة حسب الحالة الزواجية على النحو الآتي: 9.0؛\% من إجمالي حجم العينة من المتزوجات، يأتي بعدهن اللائي لم يسبق لهن الزواج بنسبة

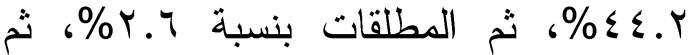

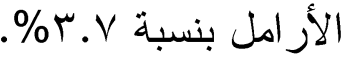
ج. تتوزع عينة الدراسة حسب حجم الأسرة على النحو الآتي: في الترتيب الأول جاءت

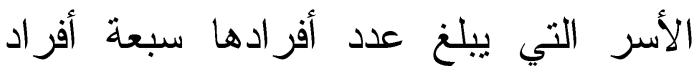
بو اقع ب. (01\% من إجمالي حجم العينة، يليها الأسر التي يبلغ عدد أفر ادها ستة أفر اد بو اقع بr\%، ثم الأسر التي بيلغ عددها خمسة أفر اد بواقع ب. 1) 1\%، ثم الأسر التي يبلغ

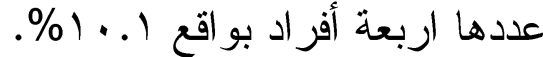

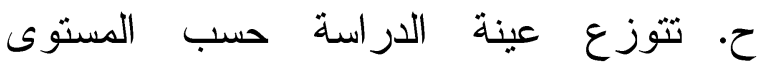
التعليمي للأبوين على النحو الآتي: - بالنسبة لتعليم الآباء احتل الأميون الترنيب الأول بنسبة 9.0٪\%، يليهخ الذين يقرؤون الابه ويكتبون بنسبة ^.7 (\%)، ثم التعليم المتوسط

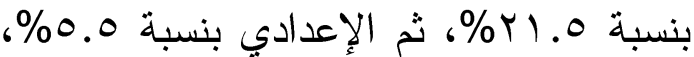
ثم الجامعي بنسبة 0.ء\%، ثم الأقل من

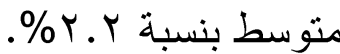
- وبالنسبة لتعليم الأمهات جاءت البيانات على النحو الآتي: في الترتيب الأول جاءت الته الأميات بنسبة ه.ع٪\%، ثم اللواتي يقرأن

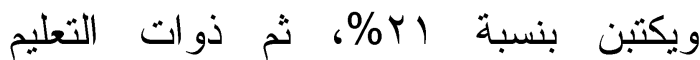
المتوسط بنسبة ع\%، ثم ذوات المؤهل المتوسط بنسبة 0\%، ثم الجامعيات بنسبة

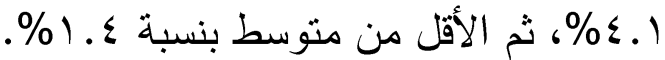

أ. تتوزع عينة الدراسة حسب السن على النحو الآتي: بلغت نسبة اللائي يقعن في الفئة

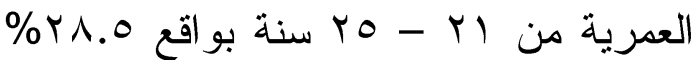
من إجمالي حجم العينة ، يليها الفئة التي ثقع

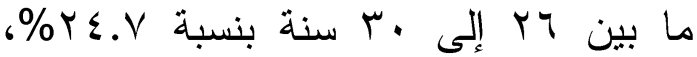
يليها الفئة التي تقل أعمار هن عن ، ب سنة

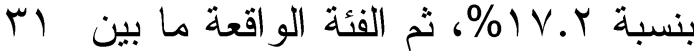

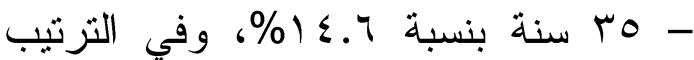
الخامس جاءت الفئة التي تزيد أعمار هن عن اع سنة بنسبة 7.9\%، وفي الترتيب الأخير جاءت الفئة التي تتراوح أعمارهن ما بين צب إلى • ع سنة بنسبة ع.0\%\%. ب. - تتوزع عينة الدراسة من حيث المهنة على المى النحو الآتي: في الترتيب الأول جاءت العاملات في مهن هامشية (بائعة متجولة، عاملة زراعية موسمية، عاملة في محل

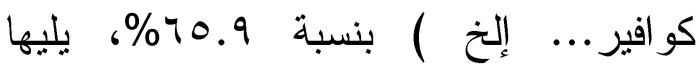
العاملات في مهن وظائف حكومية بنسبة

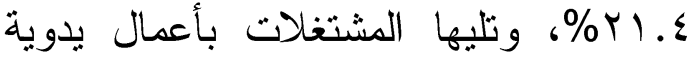
(خياطة، مصنع جريد نخل، مشخل ... إلخ) \%) Y.V ت. - تتوزع عينة الدراسة حسب الاخل على النحو الآتي: في الترتيب الأول تأتي اللائي

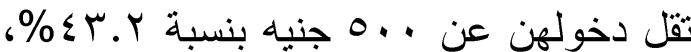

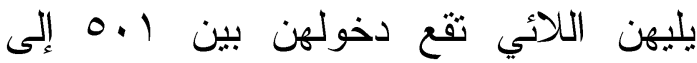

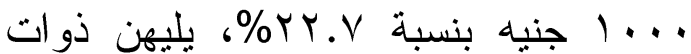
الدخل ما بين 1 ... إلى . . 10 جنيه بنسبة

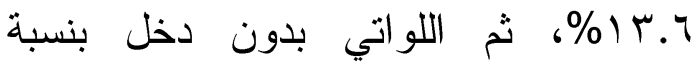
Y. Y.V F... 


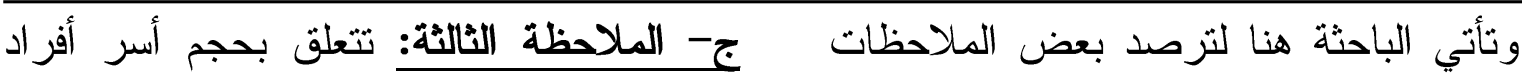

عينة البحث، إذ كثفت النتائج أن النسبة النية على أفراد عينة البحث على النحو الآتي: الغالبة من أفراد العينة جاءت من أسر البراه

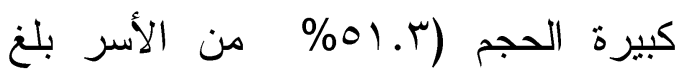

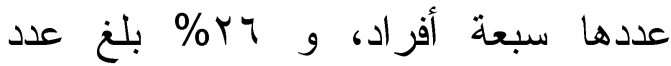

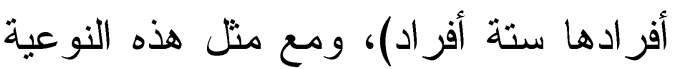

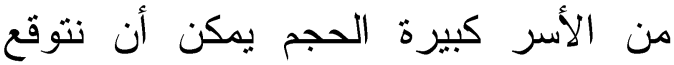

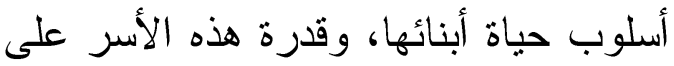

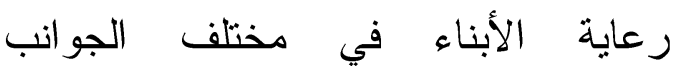
الاجتماعية و الاقتصادية و التقافية أيضا، وهو الأمر الذي جعل هذه الأسر بيئة

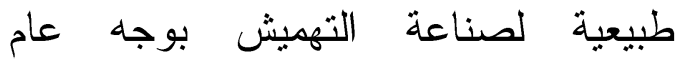
وتهميش النساء فيها على وجه الخصوص.

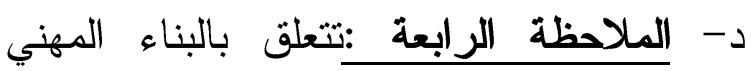
الذي توزعت عليه أفراد عينة البحث، فقاء

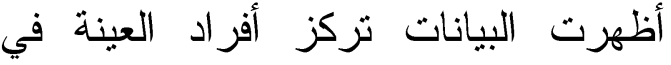
الأعمال الهامشية (بائعة متجولة، عاملة الياتة زر اعية موسمية، عامله في محل كو افير ....

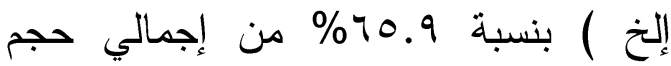

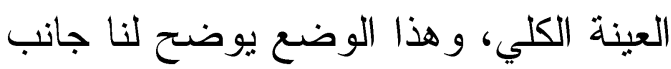

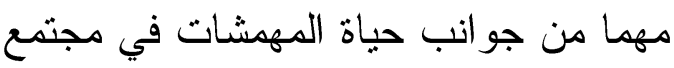
البحث، ويعطي لنا فكرة واضحة عن خصائصهن الاقتصادية سواء فيما يتعلق بمجالات العمل التي يسنطعن الحصول عليها أو حتي الاخل المتحصل من ناتج العمل في تلاك المجالات، والصورة الإجمالية لهذا الوضع الاقتصادي هو شريحة من النساء نعاني من عمل مندني وغير ثابت ومستقر وناتج من الدخل لا لغناه يمكن أن يمكنهن من الخروج من دائرة الإقصاء ، بل على العكس هي عون هون هن دائل

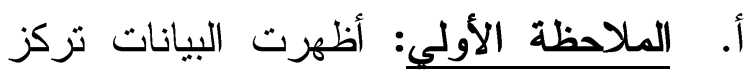
أفراد عينة البحث من المهشات في فئات

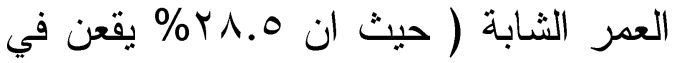
الفئة العمرية من الب ـ Y rO سنة ، يليها الفئة التي تقع ما بين بr إلى •r سنة

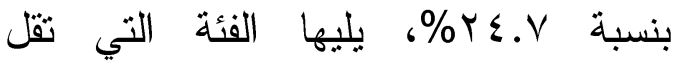

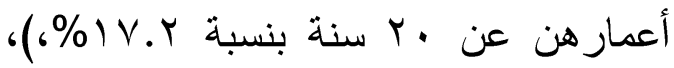

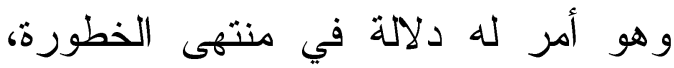
فوقوع المهشات ، ومن ثم من وقع عليهن الإقصاء في المراحل العمرية الثابة يعني ضياع قوة بشرية قادرة على الإسهام

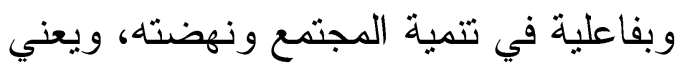
من ناحية أخرى ضياع أكثر سنوات العمر فئه

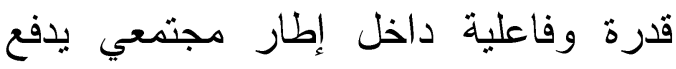
للتهميش و الإقصاء، ومن ثم بحكم على هذه الثريحة المجتمعية من النساء بالبقاء مدى الإهى الحياة في المعاناة وفقدان القدرة على تعزيز قدر اتهن على التطور وتتمية الذات. ب-الملاحظة الثانية :التي تعدها الباحثة غاية في الأهمية تتعلق بتدني المستوى النقافي للأبوين داخل أسر أفراد عينة الدراسة، إذ إذي تركزت الأمية في أسر العينة بنسبة كبيرة

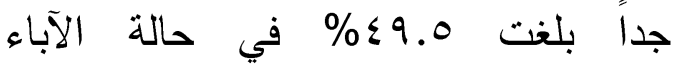

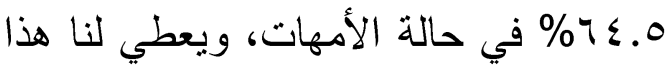
الوضع فكرة جيدة عن السياق الأسري الثقافي الذي تربت فيه أفراد عينة البحث، التهن وهو سباق ربما يكون له دور فاعل في وقوع أولئك النسوة في دائرة التهميش لكون دور لاعل 


\begin{tabular}{|c|c|c|}
\hline & & صو اب \\
\hline$\cdot,\{Y)$ & $\varepsilon, 7$ & أخضع الأسر أة داخل لتحكم باقي \\
\hline., $0 \vee 1$ & $r, v$ & علمارس أفر اد الأسرة من الإناث سنطرة كاملة \\
\hline$\cdot,\{91$ & $\varepsilon, r$ & بإخوتي الذكور للغاية مقارنة داخل أسرتي \\
\hline., 09 & ד, & الاجتماعية مشدي في المناسبات \\
\hline., $01 \mathrm{~V}$ & $r, q$ & لألأيركن مخالفة تقاليد \\
\hline סחד, י & $r, r$ & 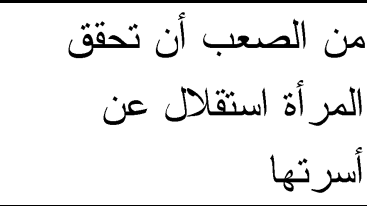 \\
\hline . TY & r, & تربية البنات لا تساعدهن تحمل المسؤولية \\
\hline., 507 & $\varepsilon, \varepsilon$ & الأسرة هو الغالي الرجالة داخل في كل \\
\hline \multicolumn{2}{|c|}{$r, 90$} & الدرجة الكلية \\
\hline
\end{tabular}

مساعدة على الوقوع في دائرة التهميش،

ومن ثم الإقصاء والاستمرار في تللك

$$
\text { الدائرة حتى الموت. }
$$

رابعا : نتائج الدراسة الميلدانية:

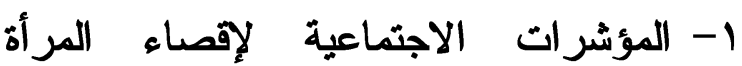

\section{المهمشة في مجتمعي البحث:}

مثّل البعد الاجتماعي لمؤشرات الإقصاء

نقطة البداية الذي حاولت من خلاله الباحثة التعرف على أهم المؤشرات الاجتماعية لإقصاء المرأة المهشة في مجتمع البحث، وقد أسفرت نتائج الدراسة الميدانية عن أن هناك عشرة مؤشرات اجتماعية لإقصاء المرأة المهية ، وهو ما يوضحه الجدول

توضح بيانات الجدول السابق رقم (ع) أن

نتائج الدراسة المبدانية كشفت عن وجود عشرة مؤشرات ذات طابع اجتماعي لإقصاء المر أة المهمشة في مجتمعي البحث، ووفقا لجدول الوزن النسبي والوسط المرجح رقم (r) فإنه من بين المؤشرات العشرة حصلت

جدول (ع) المؤشرات الاجنماعية لإقصاء المر أة المهمشة في مجتمعي البحث

\begin{tabular}{|c|c|c|}
\hline الانحر اف & المتوسط & المؤشر ات \\
\hline$\cdot, 7 \cdot 1$ & r,o & تلخضع المر أة للعديد من \\
\hline., $01 Y$ & $\varepsilon$, & 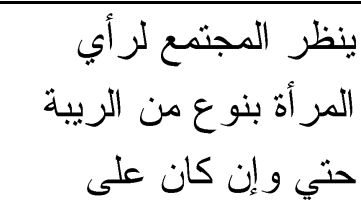 \\
\hline
\end{tabular}


كاملة على الإناث داخل الأسرة بمتوسط

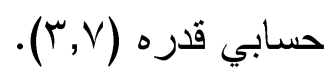

ث. في الترتيب السابع جاء المؤشر الخاص لاص بمحدودية مشاركة المرأة في المناسبات الاجتماعية بمتوسط حسابي قدره ( آبץ). ج. في الترتيب الثامن جاء المؤشر الخاص الثان بخضوع المرأة للعديد من القيود الأسرية

$$
\text { بمتوسط حسابي بلغ (ب,0). }
$$

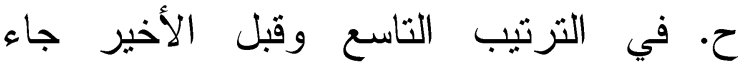
المؤشر الخاص بخلل أسلوب التربية الأسرية الذي لا يساعد الفتاة على تحمل

$$
\text { المسؤولية بمتوسط حسابي قدره (ع, ب). }
$$

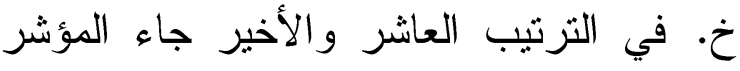

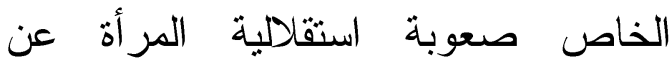

$$
\text { الأسرة بمنوسط حسابي قدره (r, ب). }
$$

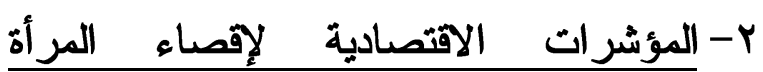

$$
\text { المهمشة في مجتمعي البحث: }
$$

تعد المؤشرات الاقتصادية ثاني المؤشرات

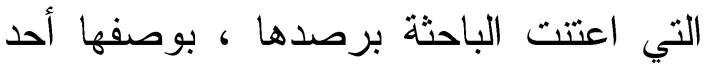
المكونات الرئيسة في تحديد ملامح الإقصاء

\begin{tabular}{|c|c|c|}
\hline \multicolumn{3}{|c|}{ في مجتمعي البحث } \\
\hline الانعياري & المتوسط & المؤشُر ات \\
\hline ס TYT & $\varepsilon, 1$ & فالمر أة العليلة مقارنة المتاحة \\
\hline
\end{tabular}

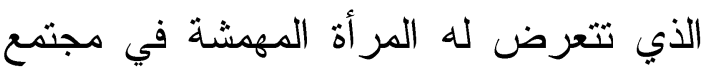

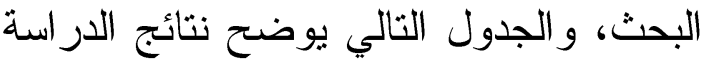

$$
\text { الميدانية في تلك المؤشر ات: }
$$

(0) المؤشرات الاقتصادية لإقصاء المر أة المهيشة
ثلاثة مؤشر ات على وزن نسبي مرتفع للغاية، حيث تراوحت متوسطاتها الحسابية ما بين

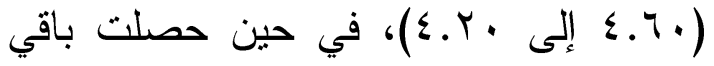
المؤشرات و عددها سبعة على وزن نسبي إلى

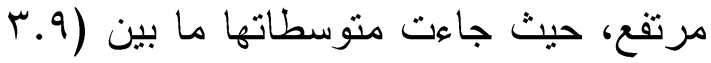
إلى ب.r. (r). وفيما يتعلق بالمؤشرات الثلاثة التي حصلت على وزن نسبي مرتفع للغاية ، فهي

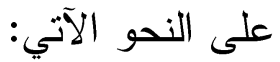
أ. في الترتيب الأول المؤشر الخاص بخضوع الأي

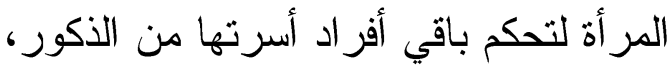

$$
\text { بمتوسط حسابي بلغ) ج. ؛). }
$$

ب.في الثرتيب الثاني جاء المؤشر الخاص بغلبة رأي الذكور داخل الأسرة بمتوسط حسابي

$$
\text { قدره (ع. گ). }
$$

ج. في الترتيب الثالث جاء المؤشر الخاص بمحدودية دور المرأة داخل الأسرة مقارنة

$$
\text { بالذكور بمتوسط حسابي قدره ( ب.ـ؛). }
$$

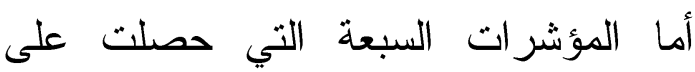
وزن نسبي مرتفع، فهي كالتالي: أ. في الترتيب الرابع جاء المؤشر الخاص فئي

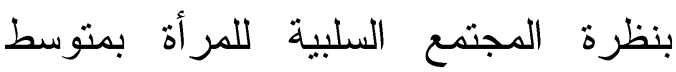

$$
\text { حسابي قدره (•.ـ). }
$$

ب. في الترتيب الخامس جاء المؤشر الخاص (0) بعدم قدرة المرأة على مخالفة الثقاليد الأسرية حنى وان كانت ضدم لدمرة مصلحة

$$
\text { المر أة بمتوسط حسابي (؟,9). }
$$

ت. في التزتيب السادس جاء المؤشر الخاص بممارسة أفراد الأسرة من الذكور لسيطرة 
مؤشرات على وزن نسبي مرتفع، حيث

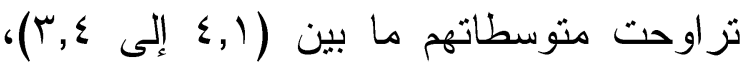
إلى جانب ذللك حصلت ثلاثة مؤشرات على وزن نسبي متوسط، وأخير ا حصل مؤشر واحد على زن نسبي منخفض للغاية. وفيما يتعلق بالمؤشرين اللذين حصلا على لى لإهي وزن نسبي مرتقع للغاية ، فقد أثشار الأول منهما

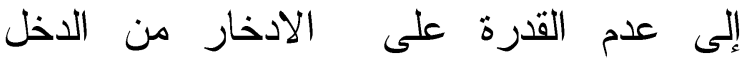
بمتوسط حسابي بلغ (آ,؛)، في حين أثنار الثاني إلى عدم كفاية الدخل لمتطلبات الحباة المعيشية بمنوسط حسابي بلغ (؟, ؟). أما المؤشرات التي حصلت على وزن نسبي مرتفع فقد جاء في الترتيب الثالث المؤشر الخاص بقلة فرص العمل المتاحة أمام المرأة مقارنة بالرجل بمنوسط حسابي قدره (1, §)،

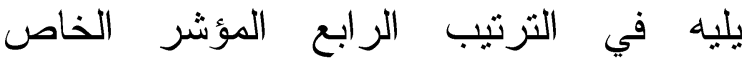
بمحدودية فرص حصول المرأة على عمل ذات دخل مرتفع بمتوسط حسابي بلغ (؟,9)، وفي التزتيب الخامس جاء المؤشر الخاص بانحسار

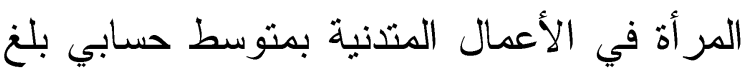
(†, (ץ)، يلي ذلك وفي الترتيب السادس المؤشر

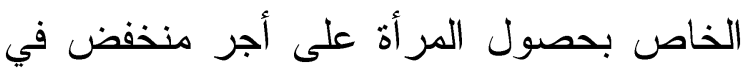
ذات الأعمال التي يقوم بها الرجال بمتوسط لجال حسابي (؟) (ץ).

أما بقية المؤشرات التي حصلت إما على وزن نسبي متوسط أو منخفض للغاية ، فنتصل بقضايا عدم عدالة الدخل الذي تحصل عليها المر أة في العمل و انحسار ها في الأعمال المؤقتنة ونظرة المجتمع السلبية لعمل المرأة وعدم قدرة

\begin{tabular}{|c|c|c|}
\hline$\cdot, \vee \circ \varepsilon$ & $r, \varepsilon$ & منحفض الذّ المر أة على أجر \\
\hline., 709 & $r, q$ & فر على عمل ذصول الت داخل أة \\
\hline$\cdot, V Y \varepsilon$ & ד, r & متدنية الغالب على أعمال \\
\hline$\cdot, 0 \wedge \mathrm{V}$ & $\varepsilon\rceil$, & لا لأستطيع الادخار من \\
\hline$\cdot, \vee \wedge 9$ & $r, r$ & 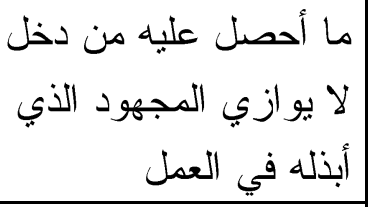 \\
\hline., $09 \mathrm{~V}$ & $\varepsilon, r$ & 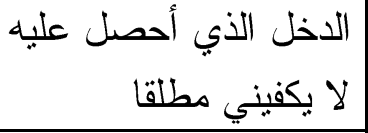 \\
\hline$\cdot, \wedge \vee q$ & $r, \wedge$ & عليها المر أة غالبا مؤقتة \\
\hline $1, Y \leq 1$ & 1.7 & 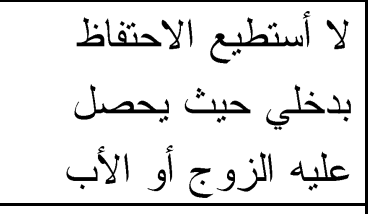 \\
\hline$\cdot, \lambda Y \varepsilon$ & r, & 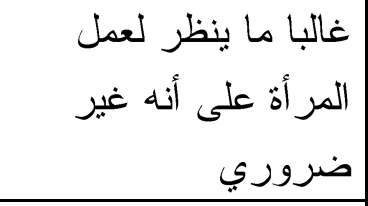 \\
\hline \multicolumn{2}{|c|}{$r, \leqslant 0$} & الدرجة الكلية \\
\hline
\end{tabular}

توضح بيانات الجدول السابق رقم (0) أن نتائج الدراسة الميدانية كثفت عن وجود عشرة

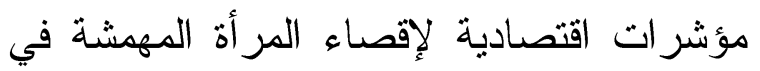
مجتمعي البحث، ووفقا للوزن النسبي والوسط المرجح المتفق عليه ، فمن بين المؤشرات العشرة حصل مؤشران على وزن نسبي مرتفع للغاية، حيث تراوحت منوسطاتها الحسابية ما

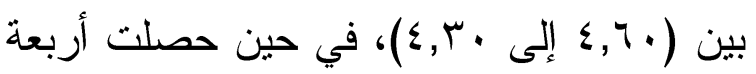




\begin{tabular}{|c|c|c|c|c|c|}
\hline & & للغاية & \multirow{3}{*}{\multicolumn{3}{|c|}{ 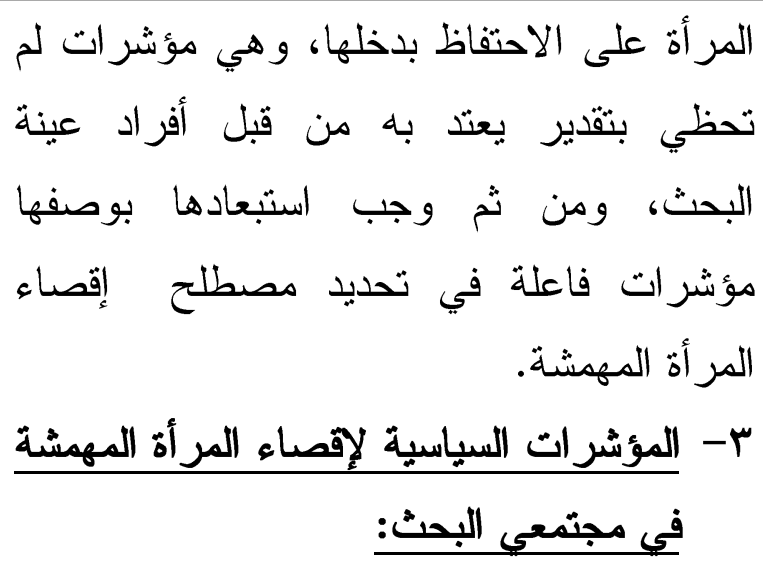 }} \\
\hline., $0 Y 1$ & $r, 0$ & الترصي على الانتخابات ضيت في & & & \\
\hline$\cdot, \Sigma \wedge \vee$ & $r, 1$ & أنشطة أشارك مطلقا في جمعية & & & \\
\hline$\cdot, \Gamma \wedge \vee$ & $\varepsilon, \varepsilon$ & 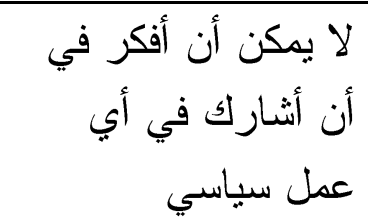 & \multirow{2}{*}{\multicolumn{3}{|c|}{ 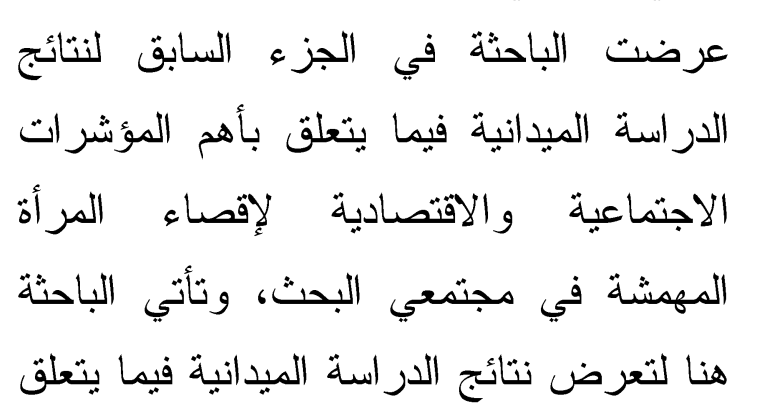 }} \\
\hline • & $1, V$ & فرص نجاح المر أة في & & & \\
\hline . & $\varepsilon, 1$ & 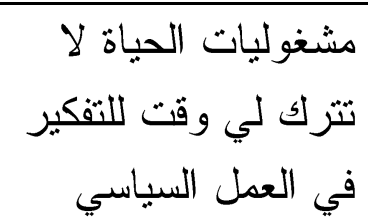 & \multirow{2}{*}{\multicolumn{3}{|c|}{ 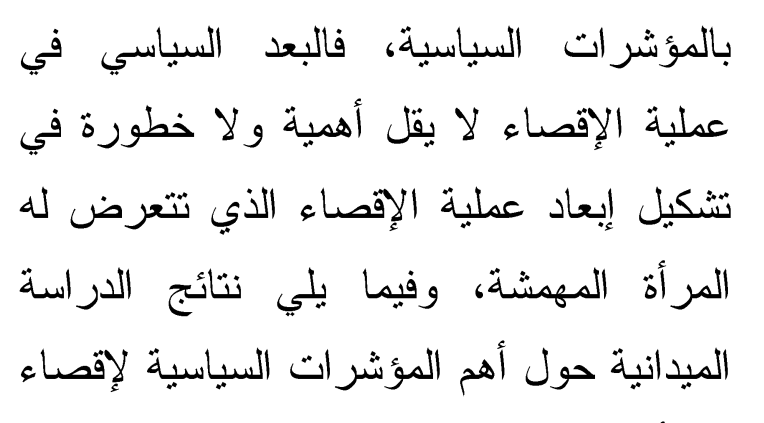 }} \\
\hline$\cdot, \leqslant 10$ & $\varepsilon$, & ضشاركة المر أة في & & & \\
\hline., 791 & 1,0 & معرفتي بالحقوق السياسية للمر أة متدنية & \multirow{3}{*}{\multicolumn{3}{|c|}{ جدول (7) المؤشرات السياسية لإقصاء المر أة }} \\
\hline., 091 & $r, r$ & العافية للمشاركة ألمهار ات العي & & & \\
\hline$\cdot, \wedge Y \leq$ & r & 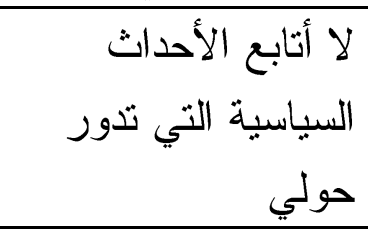 & & & \\
\hline \multicolumn{2}{|c|}{$\Gamma, \wedge 1$} & الدرجة الكلية & \multirow{2}{*}{\begin{tabular}{|l|} 
الانحر افياري \\
\end{tabular}} & & \\
\hline \multirow{2}{*}{\multicolumn{3}{|c|}{ 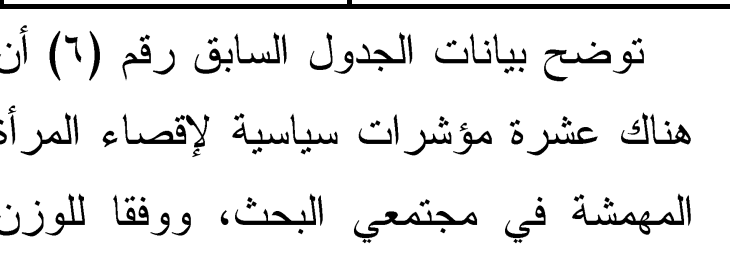 }} & & المتوسط & المؤشر ات \\
\hline & & & $\cdot, \leq 7 r$ & $r, v$ & السياسية ضتمي بالقضايا \\
\hline
\end{tabular}


ارتبط احدم بضع التصويت في

النسبي و الوسط المرجح الذي اعتمدته

الانتخابات، و الثاني عدم امتلاك المهارات

الباحثة، حصل مؤشر واحد فقط على وزن الكافية للمشاركة في العمل السياسي، و الثالث نسبي مرتفع للغاية، في حين حصلت ثلاثة تلني مستوى المعرفة بالحقوق السياسية مؤشرات على وزن نسبي مرتفع، كما حصل للمر أة والر ابع عدم متابعة الاحداث السياسية. مؤشر واحد على وزن نسبي متوسط، كما ع- المؤشرات الثقافية لإقصاء المر أة المهمشة في مجتمعي البحث:

حصلت ثلاث مؤشرات على وزن نسبي منخفض، وأخيرا حصل مؤشران على وزن

على الرغم من أهمية البعد الثقافي في تشكيل نسبي منخفض للغاية. السياقات المجتمعية المحيطة بالمر أة على وجه وبالرجوع إلى بيانات الجدول يتبين لنا أن العموم، ودوره في تحديد مكانتها ومن ثم المؤشر الذي حصل على وزن نسبي مرتفع أدوارها الاجتماعية على الخصوص، فإن ثمة للغاية، هو المؤشر الخاص بعدم المشاركة في تجاهلاً من قبل الدراسات التي عنيت ببحث أي عمل سياسي ، حيث حصل على متوسط قضايا تمكين المرأة و اقصاؤها بالبعد الثقافي، وهو الأمر الذي حدا بالباحثة إلى إفراد جزء من المقياس هدف إلى تحديد أهم المؤشرات حسابي قدره (ع,ع). أما المؤشرات التي حصلت على وزن نسبي مرتفع و عددها ثلاثة فقد جاءت على النحو التالي: الثقافية لإقصاء المر أة المهششة في مجتمع البحث، و الجدول التالي يوضح نتائج الدراسة الميدانية في هذا الشأن:

في الترنيب الثاني جاء المؤشر الخاص بعدم وجود وقت للتفكير في العمل السياسي بمنوسط حسابي قدره (1, ع)، يليه في الترثنب الثالث المؤشر الخاص بضعف مشاركة المرأة في المجالس المحلية بمتوسط حسابي بلغ (·,ع)، يليه في الترتيب الرابع المؤشر الخاص بضعف الاهتمام بالقضايا السياسية

$$
\text { بمتوسط حسابي بلغ (r,V). }
$$

أما بقية المؤشرات و عددها خمسة فقط حصل مؤشر واحد فقط على وزن متوسط ، وهو المؤشر الخاص بالإحجام عن المشاركة

جدول (V) المؤشرات الثقافية لإقصاء المر أة في أنشطة الجمعيات الأهلية عند منوسط المهمشة في مجتمعي البحث

المؤشرات
حسابي بلغ (1,1)، وحصلت باقي المؤشرات على وزن نسبي منخفض ومنخفض للغاية، 
توضح بيانات الجدول السابق رقم (V) أن

هناك عشرة مؤشرات ثقافية لإقصاء المرأة

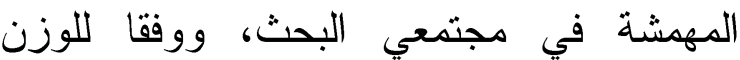
النسبي و الوسط المرجح الذي اعتمدته الباحثة، حصلت خمسة مؤشر ات على وزن نسبي مرتفع للغاية، في حين حصل مؤشران على وزن نسبي مرتفع، كما حصل مؤشر و احد على وزن عنى عنى

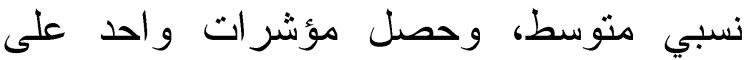

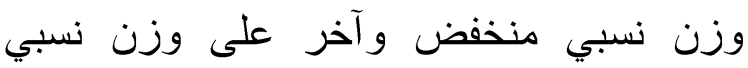
منخفض للغاية، وذلك على النحو التالي:

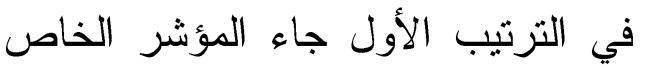
بوقوف العادات والثقاليد حائلا دون حصول المر أة على مكانتها في المجتمع بمنوسط حسابي

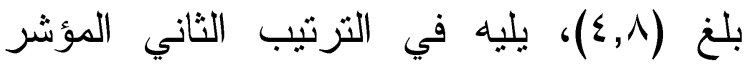

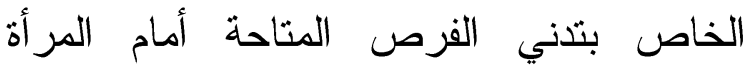

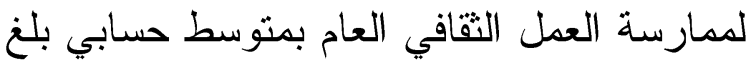

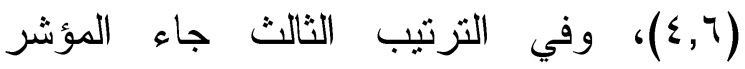
الخاص بدور البيئة الثقافية التقليدية في الحد من استغلال المرأة لكامل طاقاتها بمتوسط حسابي لئي بلغ (, ع)، يليه وفي الترتيب الرابع المؤشر

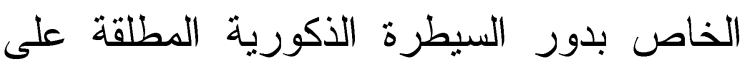
الحياة في تقليل الفرص المتاحة أمام المرأة بمتوسط حسابي بلغ (َ,ع)، وفي الترتيب

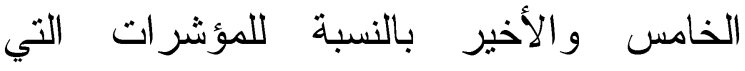
حصلت على وزن نسبي مرتفع للغاية جاء المؤشر الخاص باستمرار التمييز بين الجنسين داخل الأسرة بمتوسط حسابي بلغ (r, ؟). أما المؤشران اللذان حصلا على زن التهني

\begin{tabular}{|c|c|c|}
\hline المعياري & & \\
\hline$\cdot, \vee \leqslant \wedge$ & 1,1 & الاهنمام بتحليم البنات أقلّ \\
\hline., $0 \wedge \vee$ & $r, 1$ & بكر الاناث التخى الو لاد دون العلمية \\
\hline$\cdot, r . r$ & $\varepsilon, \wedge$ & 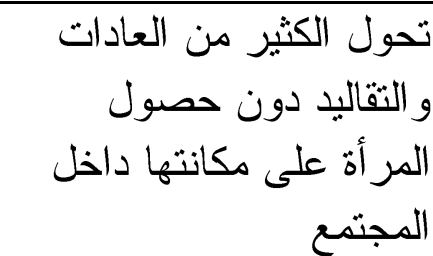 \\
\hline$\cdot, \leqslant 0 \mathrm{~V}$ & $\varepsilon, Y$ & من الأمور الممارسة التمبيز على الجنسين \\
\hline \& & $\varepsilon, 7$ & اللعام مارسة التمل التماحة المافم المر أة \\
\hline$\cdot, \varepsilon \cdot 1$ & $\varepsilon, r$ & 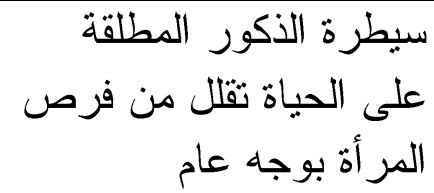 \\
\hline$\cdot, \mu q \wedge$ & $\varepsilon, 0$ & 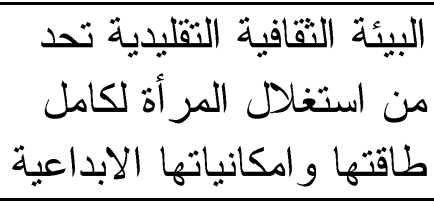 \\
\hline$\cdot, \Sigma \vee \wedge$ & $r, \Lambda$ & اللتزريب لتطوير المتاحة أمام المر أة \\
\hline ש & $r, \varepsilon$ & تحظيف المر أة باهتمام مؤسسات \\
\hline$\cdot$, OYV & $r, \varepsilon$ & سبسهم الإعلام برسم صورة \\
\hline \multicolumn{2}{|c|}{ r,Tr } & الدرجة الكلية \\
\hline
\end{tabular}
نسبي مرتفع فقد جاء الأول منهما في الترتيب 
على منوسط حسابي بلغ (ب,90) يليه البعد

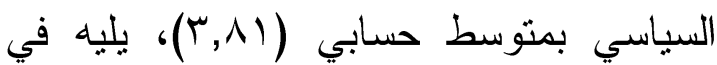
الترنيب الثالث البعد الثقافي بمتوسط حسابي بلغ (r, ب, وفي الترتيب الرابع والأخير جاء البعد الاقتصادي بمنوسط حسابي بلغ (0؛, ب). وقد جاءت جميع تللك الإبعاد عن وزن نسبي مرتفع. فضلا عن ذلك تظهر بيانات الجدول أن الدرجة الكلية لمقياس مؤشرات إقصاء المرأة المهششة جاء عند وزن نسبي مرتفع أيضا، و هو ما يعني أن هذا المقياس قد حقق الهدف من تصميمه في قياس مؤشرات إقصاء المر أة المهششة في مجتمعي البحث. צ- الفروق بين عينتي الريف و الحضر في مؤشرات إقصاء المر أة المههشة لما كانت الدراسة الميدانية التي قامت بها الباحثة قد طبقت على عينتي أحدهما تمثل المجتمع الريف و الأخرى تمثل المجتمع الحضري، فقد كان من المهم أن ثقوم الباحثة برصد الفروق بين عينتي الدراسة في تقدير اتهما لمؤشرات إقصاء المرأة المهششة في مجتمعتي البحث، والجدول التالي يوضح ذلك:
السادس وهو ذات علاقة بمحدودية فرص التدريب التي تمكن المرأة من تطوير ذاتها، حيث حصل هذا المؤشر على وزن نسبي بلغ (؟,^) بدور الإعلام في رسم صورة سلبية عن المرأة في المجتمع بمتوسط حسابي بلغ (ع, س). - ترثيب إبعاد إقصاء المرأة المهشمة في

$$
\text { مجتمعي البحث: }
$$

كثفت النتائج السابقة أن هناك أربعة إبعاد لإقصاء المرأة المهششة في مجتمعي البحث، وفيما يلي تعرض الباحثة لترتيب تلك الإبعاد وفقا للدرجة الكلبة لكل بعد: جدول (1) ترتيب إبعاد إقصاء المر أة المههشة في مجتمعي البحث وفقا للارجة الكلية

\begin{tabular}{|c|c|c|}
\hline الترتيب & المتوسط & البعد \\
\hline الأول & $r, 90$ & البعد الاجتماعي \\
\hline الر ابع & $r, \leqslant 0$ & البعد الاقتصادي \\
\hline الثاني الثي & $\Gamma, \wedge)$ & البعد السياسي \\
\hline الثالث & r,T & البعد الثقافي \\
\hline \multicolumn{2}{|c|}{$r . v}$. & الدرجة الكلية للمقياس \\
\hline
\end{tabular}

من بيانات الجدول السابق يمكن القول إن البعد الاجتماعي احتل الترتيب الأول في مقياس مؤشر ات إقصاء المر أة المهيشة، حيث حصل

جدول رقم (9) يوضح الفروق الريفية الحضرية على إبعاد مقياس مؤشرات إقصاء المر أة المهششة

\begin{tabular}{|c|c|c|c|c|c|c|}
\hline مستوى الدلالة & قيمة ت & الانحر اف & المتوسط الحسابي & ن & العينة & الإبعاد \\
\hline \multirow[t]{2}{*}{$\ldots 1$} & \multirow[t]{2}{*}{$1 \cdot \ldots \leqslant V$} & E.977Y人 & rq.V० & $1 Y$. & ريف & \multirow[t]{2}{*}{ البعد الأول } \\
\hline & & $.9 \mathrm{~V} \cdot \mathrm{VI}$ & צחצד. • & $M$. & حضر & \\
\hline
\end{tabular}




\begin{tabular}{|c|c|c|c|c|c|c|}
\hline \multirow[t]{2}{*}{. .1} & \multirow[t]{2}{*}{ • . . } & $\varepsilon . \varepsilon Y Y \cdot V$ & r.ANIA & Ir. & ريف & \multirow{2}{*}{ البعد الثاني } \\
\hline & & $. .7 r \cdot \leq q$ & |r.VA|^ & Ir. & حضر & \\
\hline \multirow[t]{2}{*}{$\ldots 1$} & \multirow[t]{2}{*}{ Y.779 } & $0.17 . V V$ & Yч.ATY & Ir. & ريف & \multirow[t]{2}{*}{ البعد الثالث } \\
\hline & & $.0 V 1 \wedge r$ & $10 . .111$ & Ir. & حضر & \\
\hline \multirow[t]{2}{*}{$\cdots 1$} & \multirow[t]{2}{*}{ Y.VqI } & $0 .\{Y 901$ & YV.0 000 & Ir. & ريف & \multirow[t]{2}{*}{ البعد الرابع } \\
\hline & &. $.7 \wedge 9 \wedge \wedge$ & צדאז.דו & Ir. & حضر & \\
\hline
\end{tabular}

الريف و الحضــر علــى البعــــ الثالـــث (السياسي) من مقيــاس إقصـــــاء المـــر أة المهمشة لصالح عينة الريف. ث. هناك فروق ذات دلالة إحصــائية عنـــ مستوى معنوية بلغ (1 +, +) بين عينتـي الريف والحضــر علــى البعــــ الرابــع

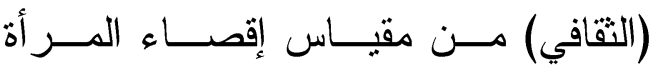
المهرشة لصالح عينة الريف. V - تباين تقديرات أفر اد العينة لمؤشرات إقصاء المر أة المهمشة وفقا لتباين المهنة تظهر بيانات الجدول التالي التبــاين فـي تقديرات أفراد عينة البحث في تقديراتهن لمؤشر ات إقصـاء المـــر أة المهمشـــة فــي ضوء تباين التوزيع المهني للعينة:
باستخدام الاختبار الإحصــائي (ت) لقبــاس الفروق بين عينتــي الدراســة مــن الريــف الف و الحضر على إبعاد مقياس إقصـــاء المــر أة المهمشة أظهرت نتائج الاختبار ما يلي: أ. هنالك فروق ذات دلالة إحصــائية عنــــ مستوى معنوية بلغ (1 +, +•) بين عينتـي

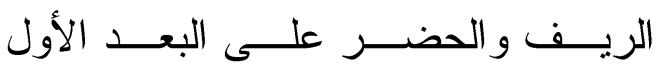
(الاجتماعي) من مقياس إقصـــاء المــر أة المهيشة لصالح عينة الريف. ب. هناك فروق ذات دلالة إحصــائية عنــــ مستوى معنوية بلغ (1 (, +•) بين عينتـي الريف و الحضــر علــى البعــــ الثـاني (الاقتصـادي) من مقياس إقصــــاء المــر أة المههشة لصالح عينة الريف. ت. هنالك فروق ذات دلالة إحصــائية عنــــ

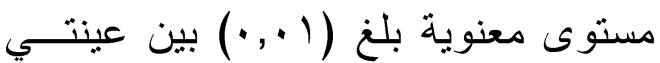
جدول (• (1) يوضح تباين أفر اد العينة على إبعاد مقياس إقصاء المر أة المهشة في ضوء توزيع العينة حسب المهنة

\begin{tabular}{|c|c|c|c|c|c|c|c|c|c|c|}
\hline \multirow[b]{2}{*}{ المتوسطات } & \multicolumn{4}{|c|}{ اختبار شيفيه لدلالة الفروق بين المجموعات } & \multicolumn{5}{|c|}{ تحليل النباين } & \multirow[b]{2}{*}{ | البعد | - البد } \\
\hline & اعدوية & وكومية & مهن هامشية & المهنة & قيمة & المربعات & الحربة & المربعوات & مصدر & \\
\hline rצ,OMrT & & & - & هامشية & \multirow{2}{*}{$\cdot, r 09$} & $I Y, \varepsilon \wedge \Lambda$ & $r$ & ro,T19 & المجمو عات & \multirow{2}{*}{ 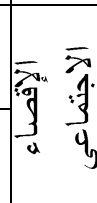 } \\
\hline rI, ro.. & & - & 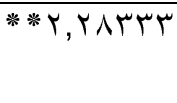 & حكومية & & $\sum 9,07 r$ & rr & חז0,0 & المجمو عات & \\
\hline
\end{tabular}




\begin{tabular}{|c|c|c|c|c|c|c|c|c|c|c|}
\hline$r Y, \wedge \ldots$ & - & $* * r, 00 \ldots$ & 1,YצYTV & اعمال & & & ro & ITYI,YYY & المجموع & \\
\hline ד, . . & & & - & هامشية & \multirow[t]{3}{*}{$\cdot, q \mu r$} & $\sum Y, Y \backslash \backslash$ & $r$ & $\wedge 0, \Sigma Y Y$ & المجمو عات & \multirow{3}{*}{ 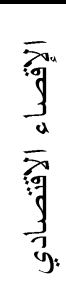 } \\
\hline$r \varepsilon, 0 \ldots$ & & - & $* * 1,0 \ldots$ & وكو مية & & $\leqslant 0,0$ ४ 9 & سוr & $10 \cdot r, \wedge \ldots$ & المجمو عات & \\
\hline$r \varepsilon, r \ldots$ & - & $* * \varepsilon, \vee \ldots .1$ & $1 . r \ldots$ & بدوية اعمال & & & ro & IONA, YYY & المجموع & \\
\hline זسז,ותז & & & - & هـثنية & \multirow[t]{3}{*}{$\cdot, 0 \wedge$. } & $1 \%, Y 70$ & $r$ & rT,Orq & المجمو عات & \multirow{3}{*}{$\begin{array}{l}\overline{3} \\
3 \\
3 \\
\overline{3} \\
\overline{3}:\end{array}$} \\
\hline $11,07 Y 0$ & & - & $* * \Upsilon, O V \cdot \wedge r$ & وكو مية & & YY,ATr & מש & $V \leqslant 0, \varepsilon I V$ & المجمو عات & \\
\hline$r_{1, r \ldots}$ & - & **r,orvo. & $1, .747 V$ & بدوية اعمال & & & 00 & $V \wedge 1, \ldots$ & المجموع & \\
\hline זسזו,וני & & & - & هامشية & \multirow[t]{3}{*}{ • } & $\{1, \backslash \backslash 1$ & $r$ & $\wedge r, \varepsilon Y r$ & المجمو عات & \multirow{3}{*}{ 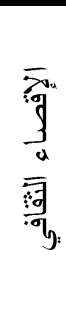 } \\
\hline$r_{., 0 T r_{0}}$ & & - & $* * Y, 0 ૫ \cdot \lambda r$ & وكو مية & & $\varepsilon \varepsilon$, Or $q$ & מז & $1 \varepsilon \cdot r, \wedge \ldots$ & المجمو عات & \\
\hline$r q, r \ldots$ & - & **r, Orvo. & $1, .000 \mathrm{~V}$ & يدوية اعمال & & & ro & $1 \leqslant \Lambda \Lambda, Y Y Y$ & المجموع & \\
\hline
\end{tabular}

المهن الهامشية و أصحاب الوظائف الحكومية

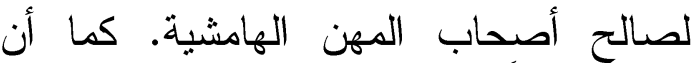
هناك تبايناً بين أصحاب المهن البدوية

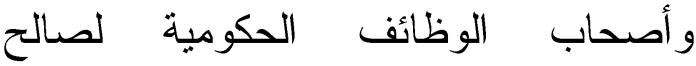
أصحاب المهن اليدوية.

ج. هنالك تباين بين أصحاب المهن المختلفة (هامشية، حكومية، بدوية) على البعد الثالث (السياسي) من إبعاد مقياس مؤشرات إنهاء إنهاء

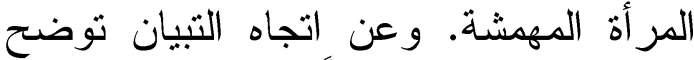
البيانات أن هناك تبايناً بين أصحاب المهن

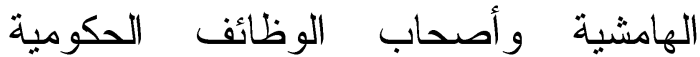

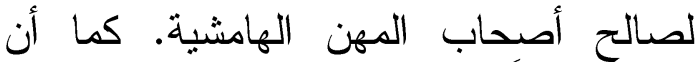
هناك تبايناً بين أصحاب المهن اليدوية

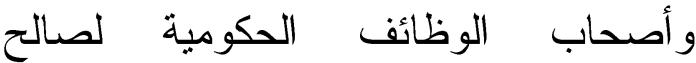
أصحاب المهن اليدوية.

د. هناك تباين بين أصحاب المهن المختلفة

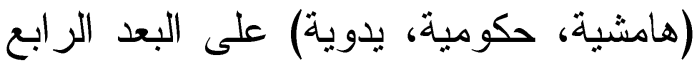
(الثقافي) من إبعاد مقياس مؤشرات إقصاء

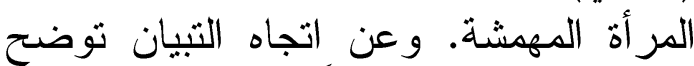

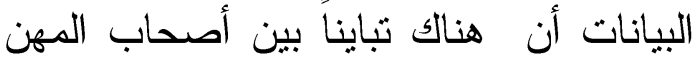

باستخدام الاختبار الاحصائي تحليل التهائ التباين أحادي الاتجاه (أنوفا) لقياس التباين بين فئات الدراسة المختلفة حسب المهنة على إبعاد مقياس إقصاء المر أة المهمشة، أظهرت نتائج الاختبار ما يلي: إهاء أ. هناك تباين بين أصحاب المهن المهن المختلفة (هامشية، حكومية، يدوية) على البعد الأول

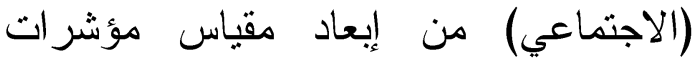

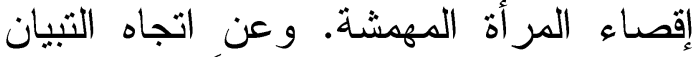
توضح البيانات أن هناك تبايناً بين أصحاب أنهاب المهن الهامشية و أصحاب الوظائف الحكومية

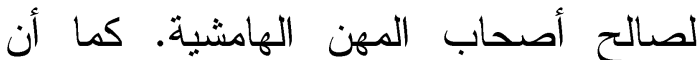
هناك تباينا بين أصحاب المهن اليدوية

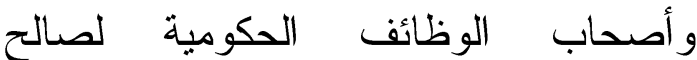
أصحاب المهن اليدوية. ب. هناك تباين بين أصحاب المهن المهن المختلفة

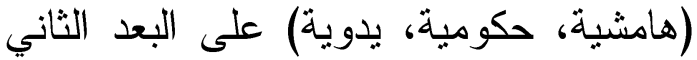

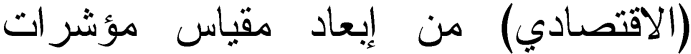
إقصاء المرأة المهمشة. وعن التهاه التهاه التبيان

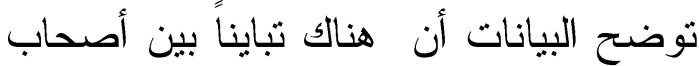


العدوم، وهي حالة مرهونة بطبيعة المجتمع الأبوي وسيطرة العقلية البطريركية ، كمانه

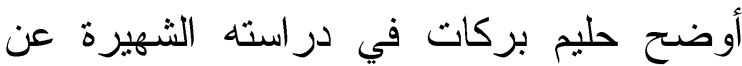

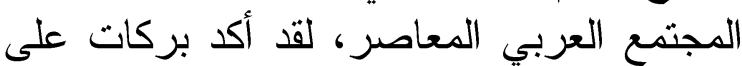
أن الأسرة العربية هي أسرة أبوية المنشأ،

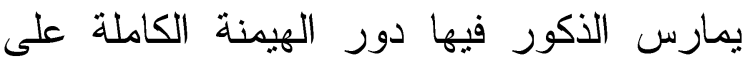

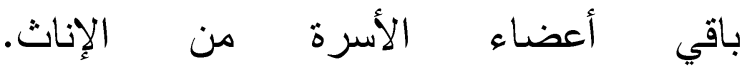

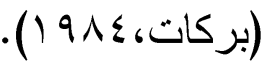

وفي ظل تلك السيطرة التي يمارسها الأكور داخل الأسرة في مجتمعي البحث ، نجد

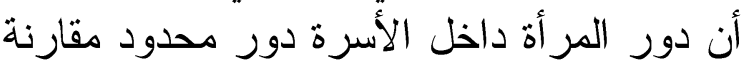
بدور باقي أفراد الأسرة من الرجالد الأن دورة وربما

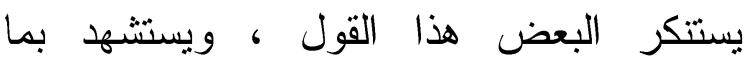

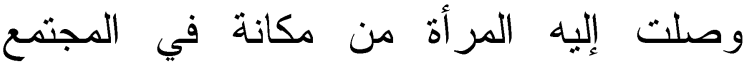
المصري المعاصر، وما حققته من مكاسب،

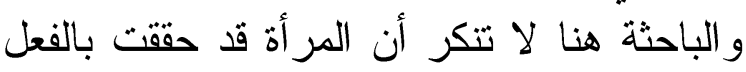

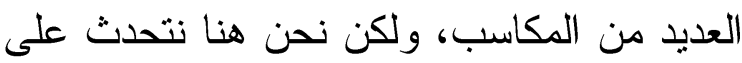

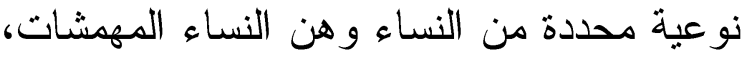
وهن في الغالب يقعن في دائرة المرأة الفقيرة، وفي أسر تهيمن عليها السلطة الذكورية، وهي سلطة كما أكد عليها هشام شرابي، تهول عهول دول

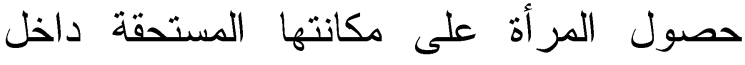

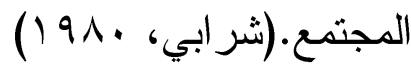
وهنا تود الباحثة الإشارة إلى أنى أن تلك

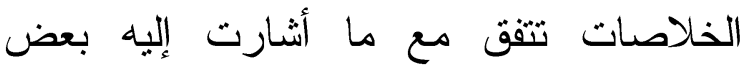

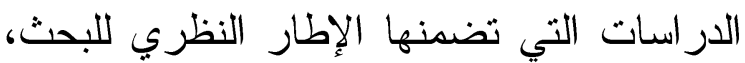

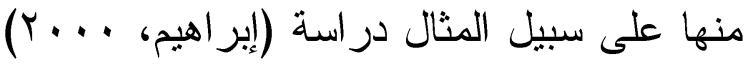
التي أكدت على أن الأسرة المصرية تلعب دورا كبيز ا في خلق حالة من التمايز بين الأكور التيرة

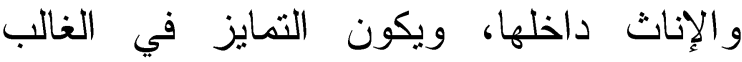
لصالح الذكور على حساب الإناث وفي كافة

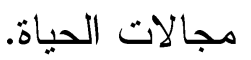

ب. وبمراجعة المؤشرات السبعة الباقية نجدها

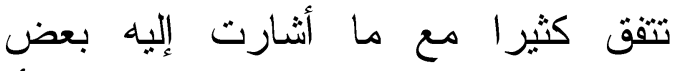
الدراسات السابقة في توصيفها لحالة المر أة

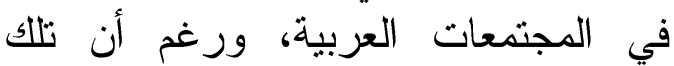

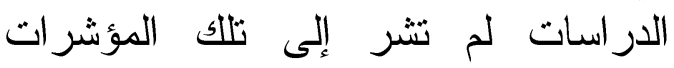

الهامشية و وأصحاب الوظائف الحكومية لصالح أصحاب المهن الهامشية. كما أن هناك تبايناً بين أصحاب المهن البدوية

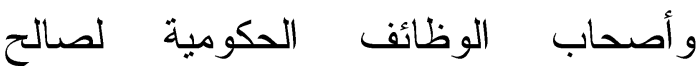
أصحاب المهن البدوية.

\section{خامسا : مناقشئة النتخائج}

عرضت الباحثة في الجزء السابث النتائج التي خلصت إليها الدراسة الميدانية، وتأتي هنا لتناقش هذه النتائج في ضوء الإطار النظري

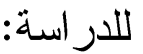

1- إجابة على السؤال الأول المتعلق بأهم الأمئ

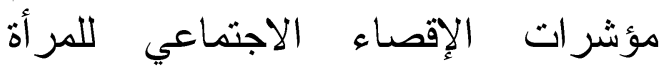

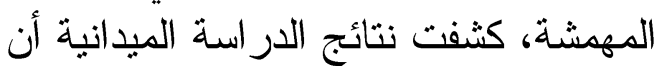
هناك عشرة مؤشرات تكشف عن الإقصاء الاجتماعي الذي تتعرض له له المرأة أني في

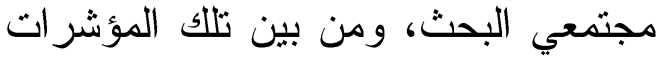
العشرة كشفت البيانات الاحصائية عن أن أن هناك ثلاثة مؤشرات حصلت على وزن الثن

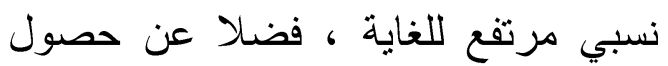

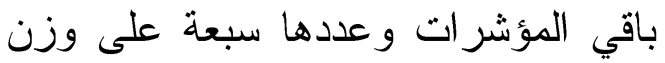

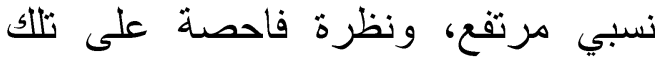

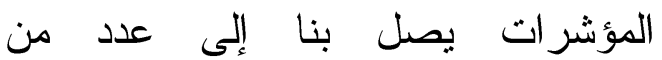
الملاحظات على النحو التالي:

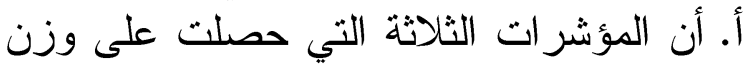
نسبي مرتفع للغاية تحيل جميعها إلى ما يمكن الفئن أن نطلق عليه بنية المجتمع الذكورية المدعمة من قبل النظام الأسري السائدة في المجتمعات

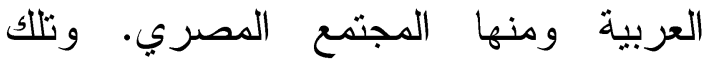
الملاحظة تثقق مع ما سبق و أشارث إليه

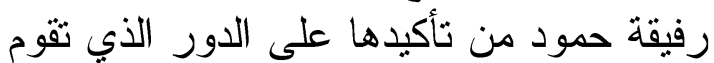

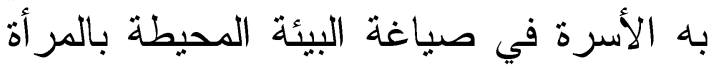

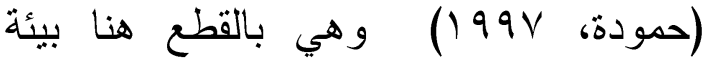

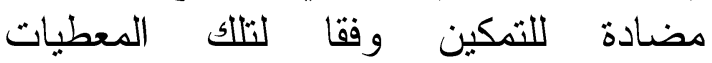
الاجتماعية.

إن خضوع المرأة أتحكم باقي أفراد أسرتها من الذكور ( محور المؤشر الأول) هي

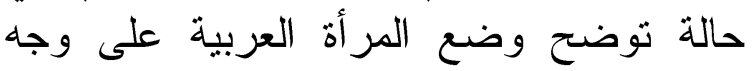


ذلك السياق الذي يحتل فيه الذكور قمة هرم السلطة داخل المجتمع بأكمله وليس داخل الئل

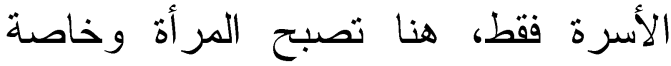

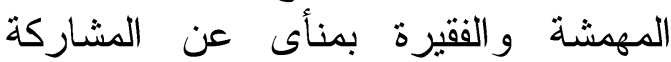

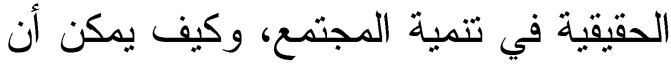
تتحقق تلك المشاركة وكيف يمكن أن تحقق فئه

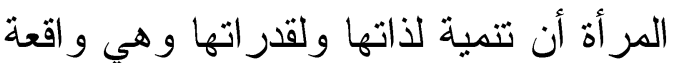

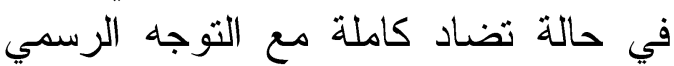
المعلن من قبل الدولة نحو تمكين المر أة. ث. و هنا نأني للماحظة الر ابعة على مؤشرات

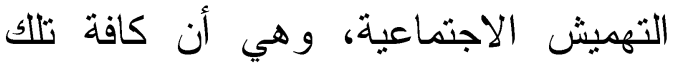
المؤشرات تصب في خانة تعمل ضد تمكين

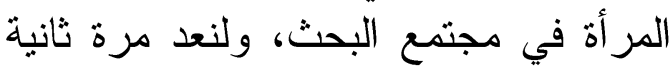
إلى مفهوم التمكين كما طرحته الباحثة في في لئي

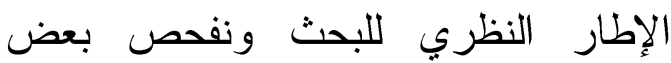

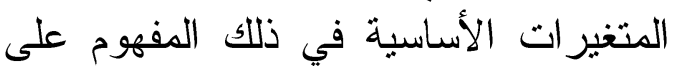
النحو التالي: التمكين هو تعزيز القدرات عند النساء (Naz,2010)، التمكين عملية تتضمن ادر الك المر أة لذاتها وسيطرتها علي

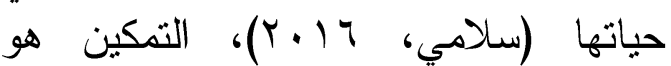

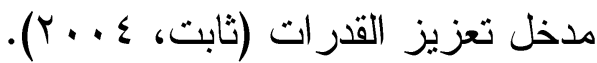
من هذه المعاني التي أعطيث لمفهوم تمكين

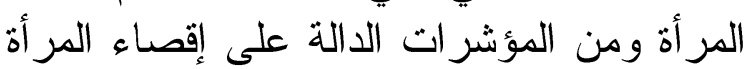

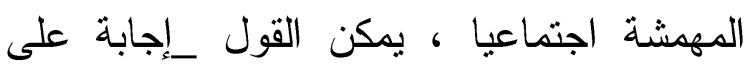
السؤال الذي طرحته الباحثة في نهاية تعريفات

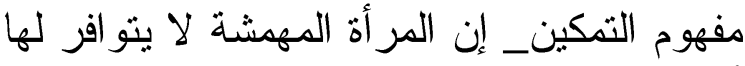
أي معطيات اجتماعية تحقق لها التمكين. r- إجابة على السؤال الثاني المتعلق بأهم مؤشرات الإقصاء الاقتصادي للمرأة المهوشة

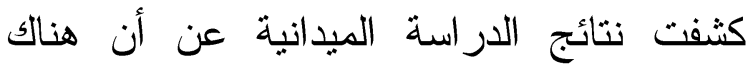

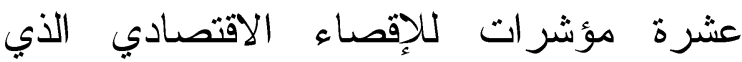

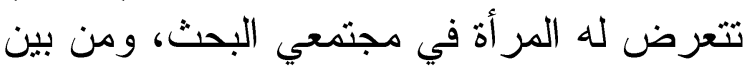

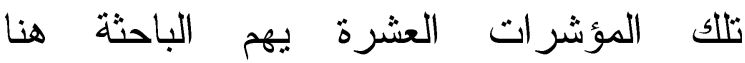

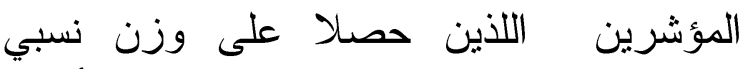
مرتفع للغاية، إضافة إلى المؤشرات الأربعة

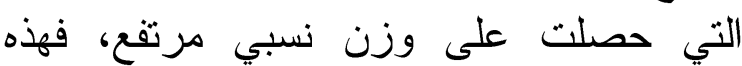

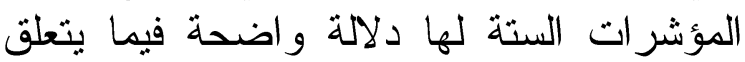

بوصفها دالة على حالة إقصاء المرأة في

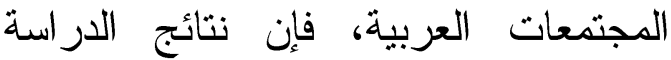
الراهنة أكدت تلك العلاقة الوطيدة بين تلك فئك

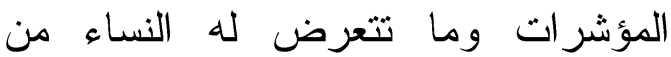

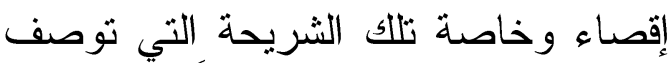
بالنساء المهمشات، ولعل و احداً من أهم تلك لته

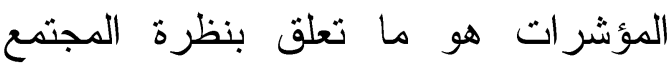

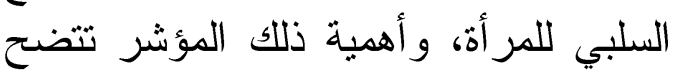

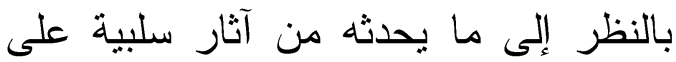

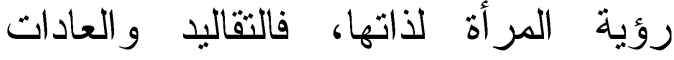

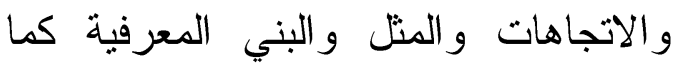

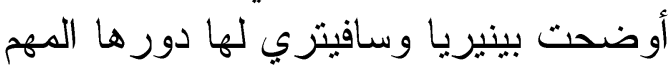
في تشكيل رؤية المرأة لذاتها ودور ها في لئي دورها

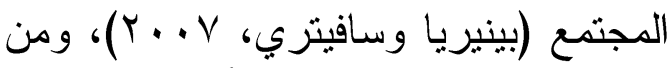

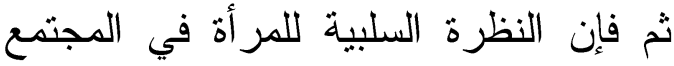

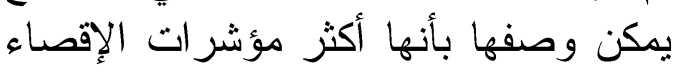

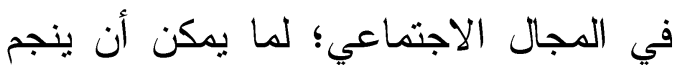
عنها من تداعيات غاية في السوء بالنسبة النية

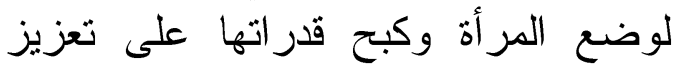

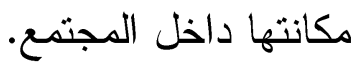

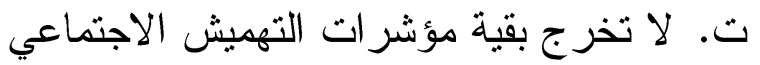

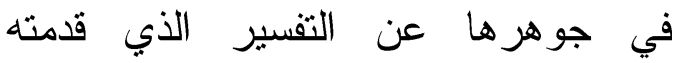
الباحثة سابقا المتمثل في التأثير السلبي الذي تمارسه بنية المجتمع الأبوي على فئى

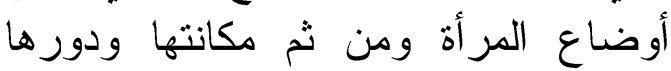
داخل المجتمع، ولنتظر إلى تلك المؤشرات على التو الي: عدم قدرة المر أة على مخالفة

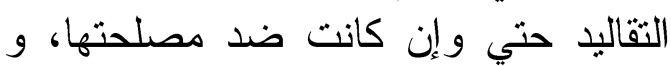

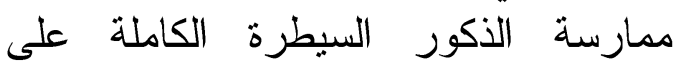
الإناث داخل الأسرة، و محدودية مشاركة

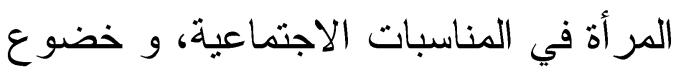

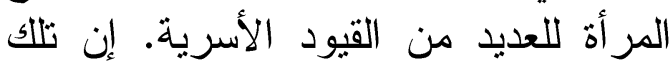

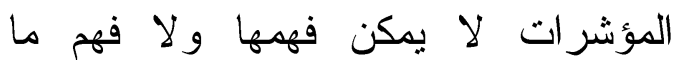
تمارسه من تأثير سلبي على مكانة المرأة

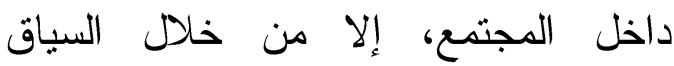

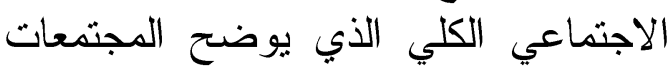

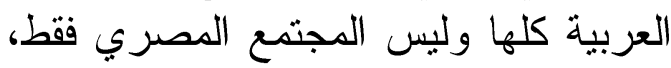




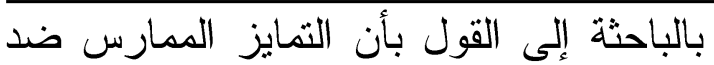

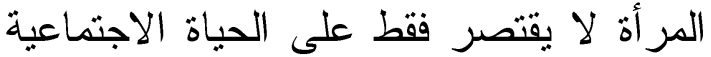
بل يمتد إلى الجانب الاقتصادي من حياة العياة

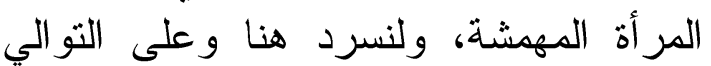

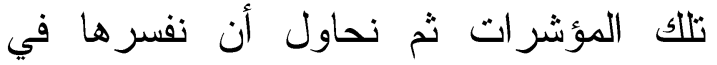
ضوء ذلك المتصل الاجتماعي الاقتصادي فئري المرتبط بحركة التمايز ضد المر أة في مجتمع الأنمائ البحث.

جاءت المؤشرات الأربعة على التوالي

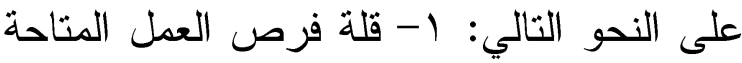

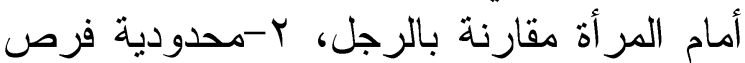

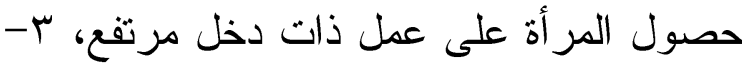

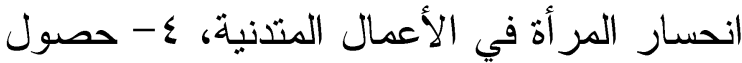

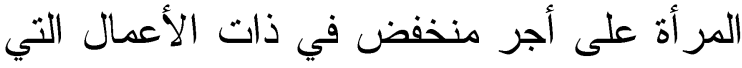

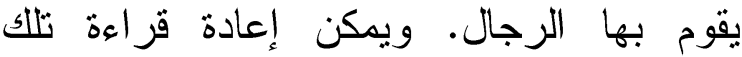
المؤشرات الأربعة في عبارة واحدة: ثمة تمايز الرادي ضد المرأة المهشة في الاربة في القطاع الاقتصادي يفضي إلى تحقيق نوع من الإقصاء لاء لا يختلف

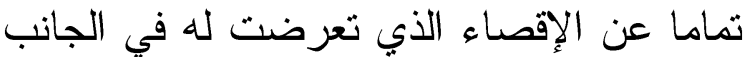

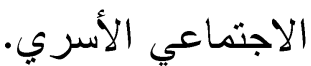
ويمكن أن تقدم الباحثة قراءة ثانية لهذه

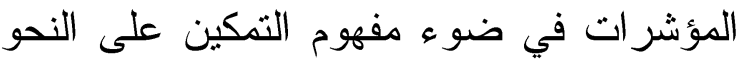

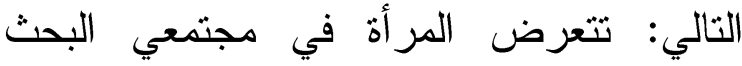

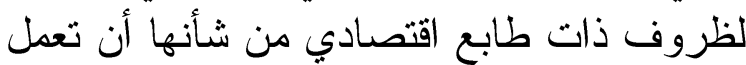

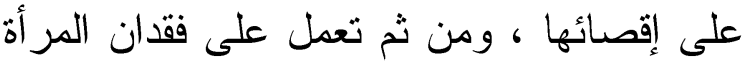
القدرات التي تمكنها من تحقيق ذاتها ومكانتها

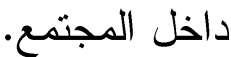

وتتفق تلاك النظرة التي خلصت إليها

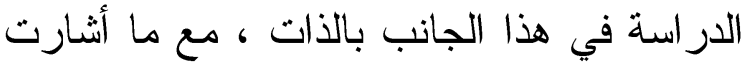

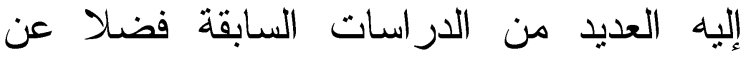
الثقارير الدولية والمحلية، فنترير المرأة العربية

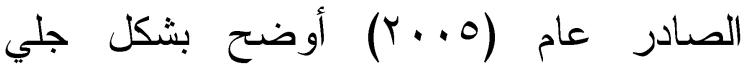
الصعوبات الاقتصادية التي تتعرض لهاب الها النساء

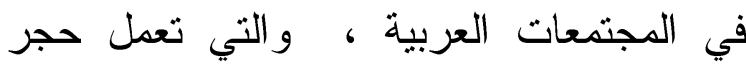
عثرة في طريق التمكين (البرنامج الإنمائي

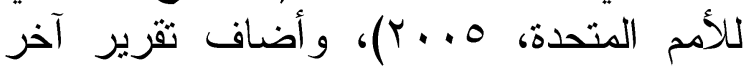
صادر عن الإسكوا أن النساء في المجتمعات آندات

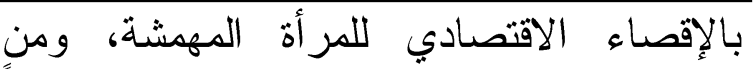
استعرض تلك المؤشرات رصدت الباحثة عددا من الملاحظات على النحو التالي: أ. ارتبط المؤشران اللذان حصلا على على وزن التحن مرتفع للغاية بقضية الدخل، حيث أثنار الأول

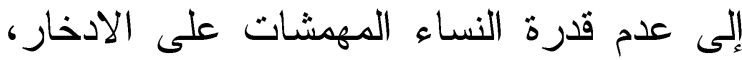

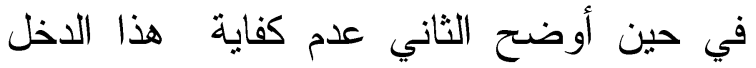

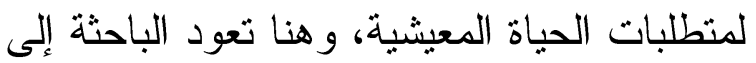

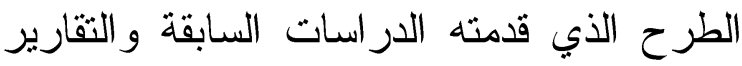
الدولية والمحلية حول العلاقة القالية القوية بين

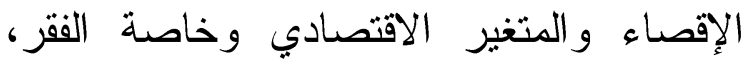

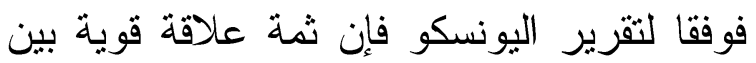
الفقر وبين الإقصاء الذي تتعرض لإن له

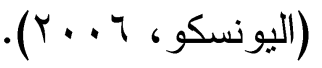

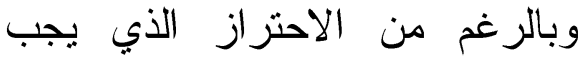

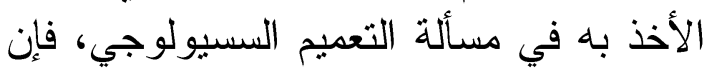

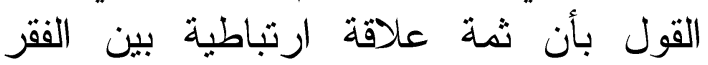

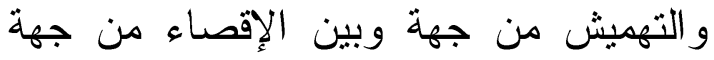
أخرى مسالة لا تحتاج إلى أدلة إمبريقية،

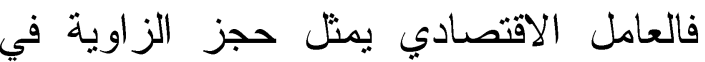
مسألة الإقصاء، وبالتالي الوجائل الوجه المقابل لله وهو التمكين، فإذا كانت الظروف الإقتصادية الإناية

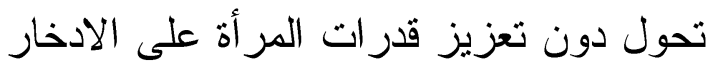
وكفاية دخلها للوفاء بمنطلباتها المعيشية ، فإن الان

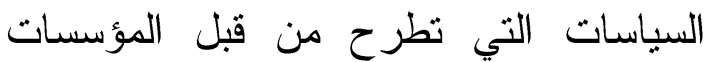

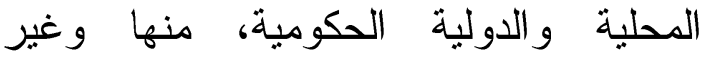
الحكومية يجب أن تصب جل الهتمامها على الى

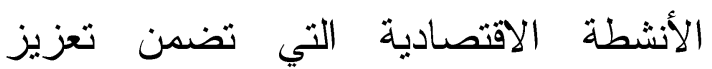
قدرات المرأة في جوانبها الاقتصادية، ومن تصني

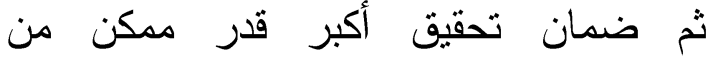
الإجراءات التي تفضي نحو تمكين المرأة وبغير ذلك سوف تأني السياسات التي تداعي

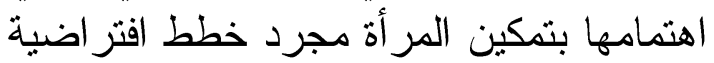
بعيدة كل البعد عن الواقع الذي تعيشه المرد أة أمبة الموشة. ب. إن تأمل المؤشرات التي حصلت على ألى وزن نسبي مرتفع و عددها أربعة ، يفضي المي لئي 
المهمشة في مجتمع البحث، وقد كشفت النتائج الميدانية عن أن هناك عشرة مؤشرات لحالة

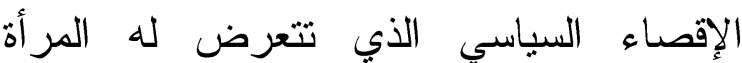

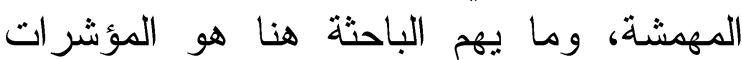

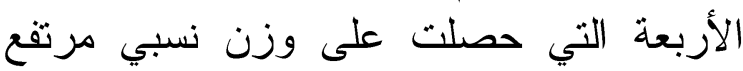

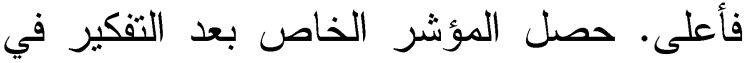

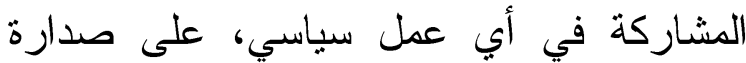

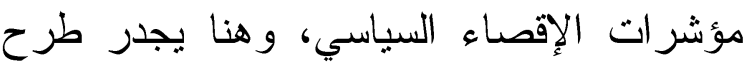
السؤال التالي: ما أهمية هذا المؤشر على التئي وجنه

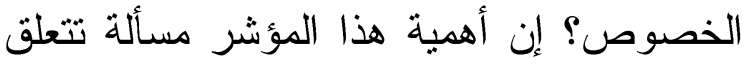
بالسياق الاجتماعي والاقتصادي بل الإن والسياسي

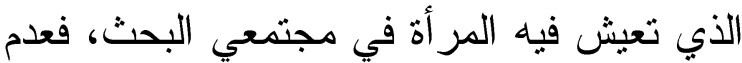

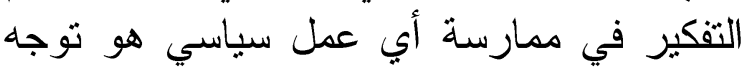

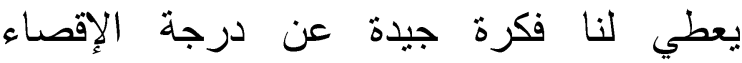
السياسي الذي تعيشه المرأة في مجتمع البحث؛ درة الأهاء

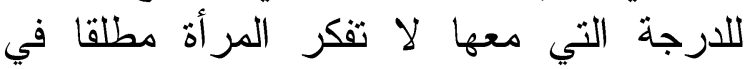
عملية المشاركة السياسية رغم أهميتها. وقد اكتملت صورة الإقصاء ذات الطيات الطابع

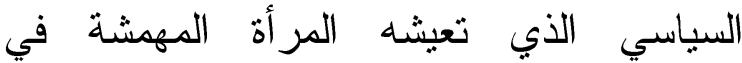
مجتمعي البحث ، بالنظر إلى المؤشرات الثيلاثلة

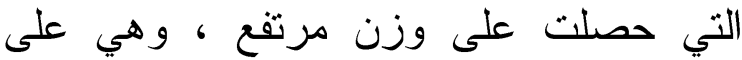

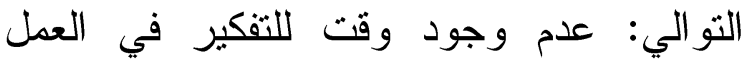
السياسي، و ضعف مشاركة المر أة في الدجالس المحلية، و ضعف و ضالافيفمام بالقضايا السياسية.

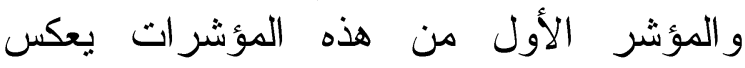

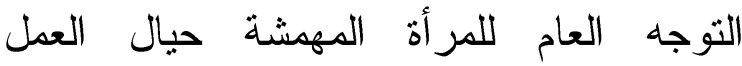

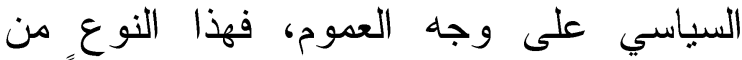

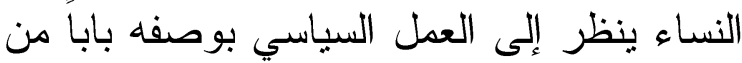

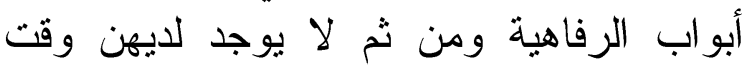
لممارسته، و هذا نوع من الإعر اض الإدي الذي يحيل

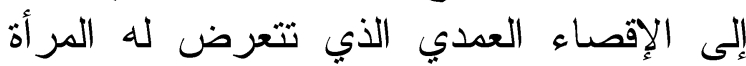

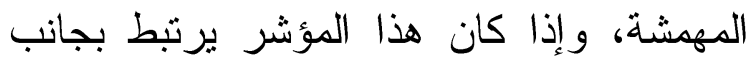

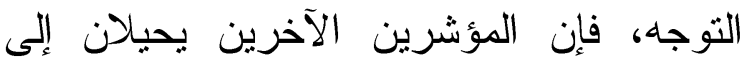

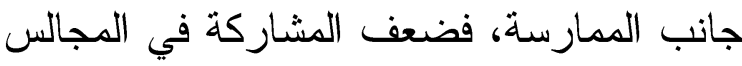
المحلية وضعف الاهتمام بالقضايا السياسية الهالية

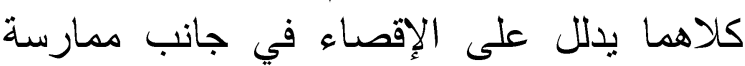

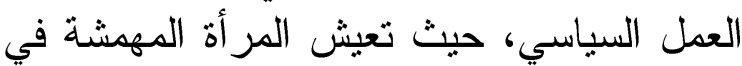

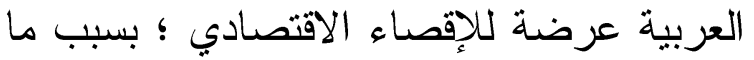

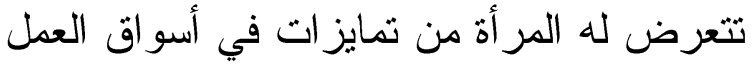

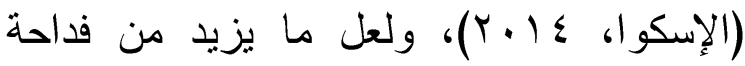

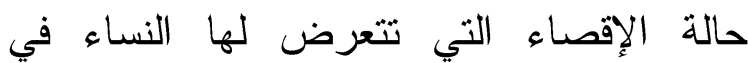

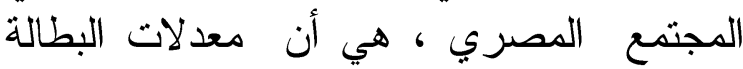

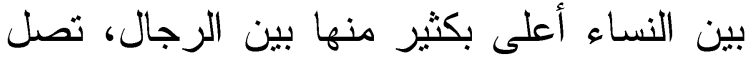

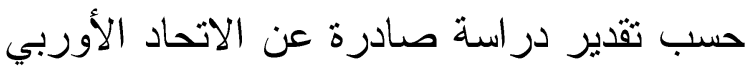

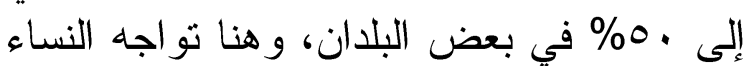
العربيات الثابات على حد تعبير التقرير معضلة الإنلة

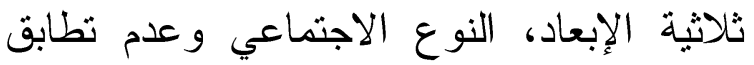

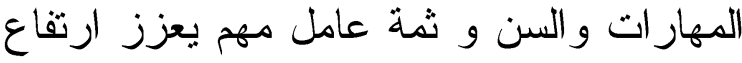

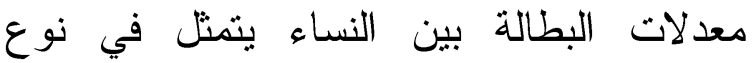

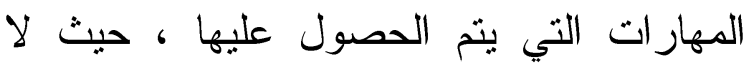

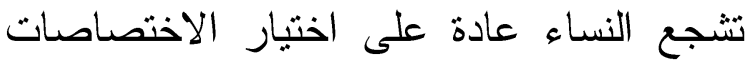

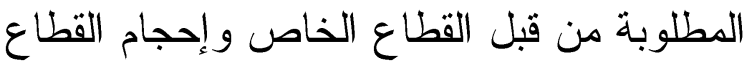

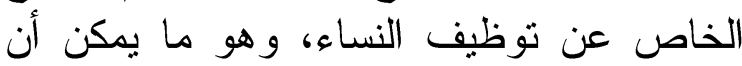
يعيق قدرة النساء على العثور على وظى وظائف مناسبة في القطاع الخاص. (مؤسسة التّريب

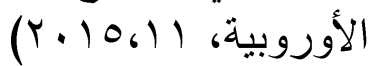

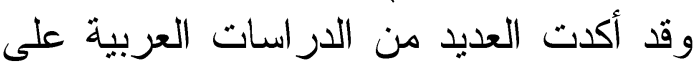

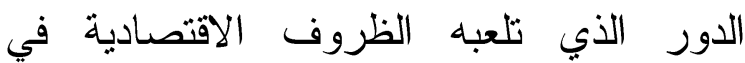
تهميش النساء ، ومن ثم الحد من قدر اتهن على لألى

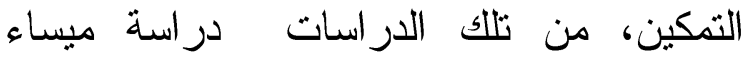

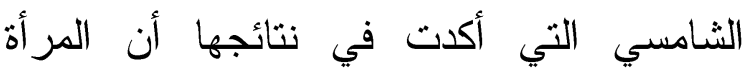
العربية تواجه العديد من التحديات الاقتصادية المرتبطة بسوق العمل، في مقدمتها صعوبة العبة التهادية

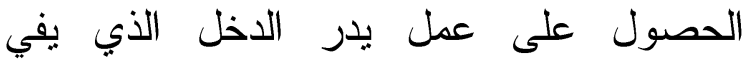

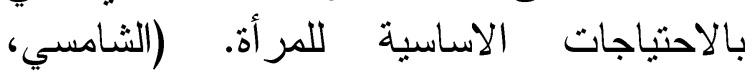
(r...r

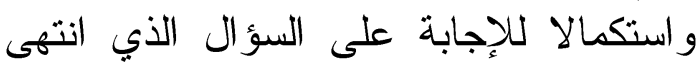
به عرض الباحثة لمفهوم التمكين، يمكن القول هنا بأن السياق الاقتصادي الذي تعمل خلادله

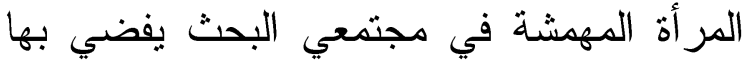
إلى حدوث نوع من الإقصاء الاقتصادي، إقصاءة يفقدها القدرة على التمكين. ب- مثلت مؤشرات الإقصاء السياسية الملدح

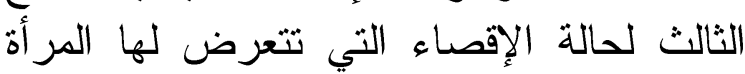


فاحصة إلى تلك المؤشرات خاصة التي

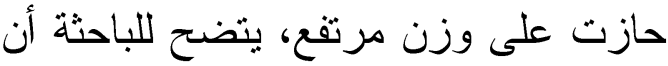

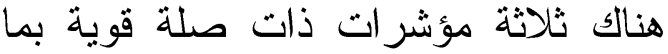

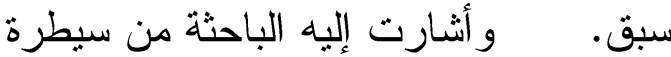

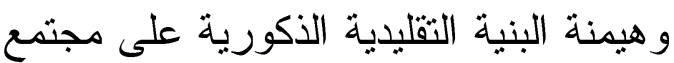
البحث وتأثثر ذلك على إقصاء المرأة عما لكا

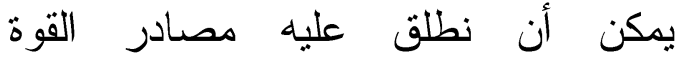
الاجتماعية أو رأس المال الون الاجتماعي،

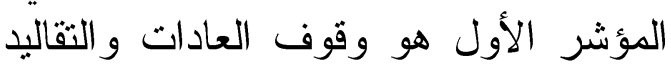

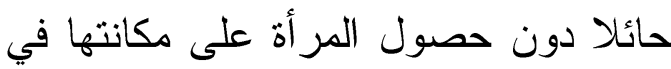

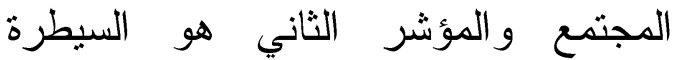
الذكورية المطلقة، والثالث استمر ار التمييز بين الجنسين داخل الأسرة. وربما يشكك البعض في تلك النتيجة من الترة باب أن المرأة قد تحررت في العقود الأخيرة

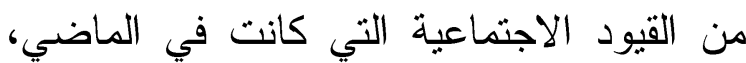
و على الرغم من أن هذا القول يمكن أن يكون صحيحا بالنسبة لثريحة محددة من النساء في في الني النياء المجتمع المصري، وهي الثريحة التي اتاحت

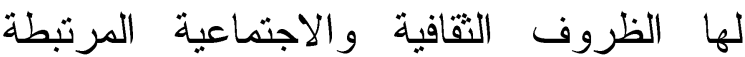

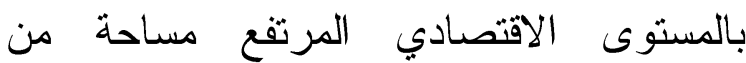

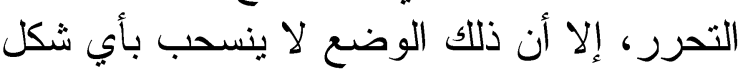
من الأشكال على النساء في المناطق لإن الريفية والحضرية الفقيرة و المهمشة، فهذان فئني المجتمعين

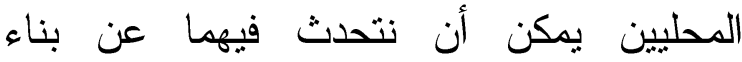
اجتماعي ثقافي تقليدي ما زالت العقلية التهية الذكورية

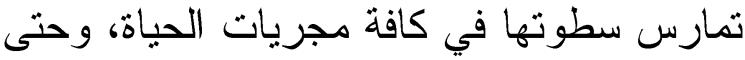

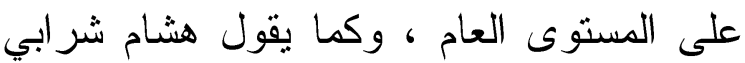
فإن الأبوية ما زالت متجذرة والت وأن ثمة أبوية

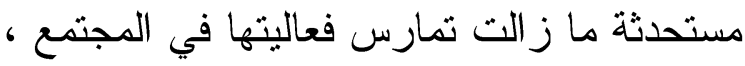

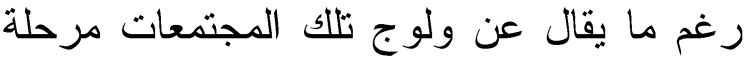
الحداثة، ولكنها و على حد تعلى تعبيره حداثة قشرية.

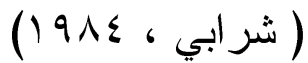

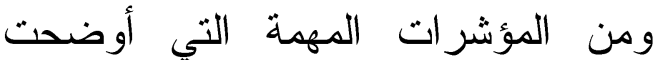

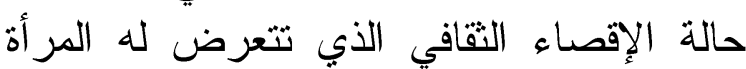

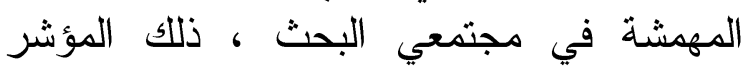
الخاص بتدني الفرص المتاحة أمام ممارسة
سياق لا يسمح لها بالمشاركة السياسية ولا حتي لإسي بالإهتمام بالقضايا ذات الطابع السياسي.

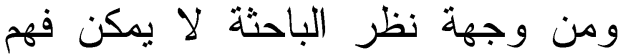
هذا الجانب من الإقصاء السياسي عن الجانب لإنب الإني السابق وتقصد به الإقصاء الاقتصادي، فالحياء الإنياة

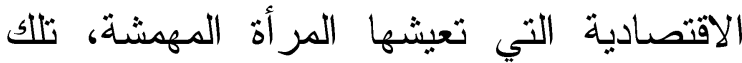

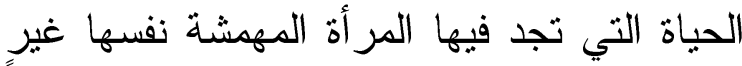
قادرة على الحصول على عمل يدر لهاء لها دخلا

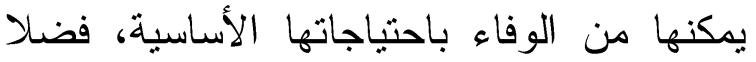

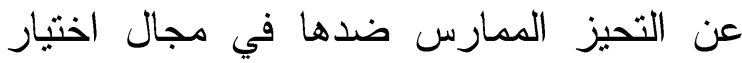
العمل و الدخل الذي تحصل عليه من ذلك العمل، فئل كل تلك الظروف من المنطقي أن تتعكس سلبيا على الحياة السياسية للمر أة، فكيف لامر أن لأن لا تجدي

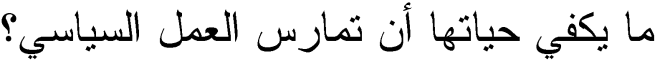

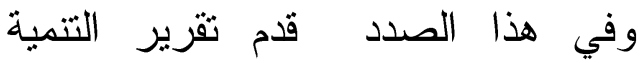
البشرية العالمي عام 1990 فكرة معيار تمكين المرأة لقياس إسهام المرأة التي يعكسها الدخل فئل فئل لكل فرد ، وحصة المرأة في المراكز المهام المهنية

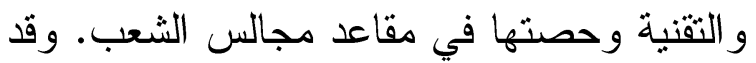
وجد أن ترتيب العالم العربي أقل من أية منطقة

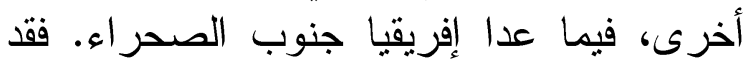
حصلت المنطقة على أقل نسبة لمشاركة المرأة أنمان

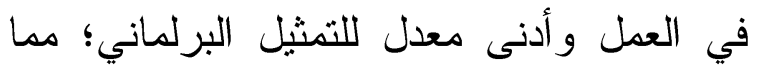

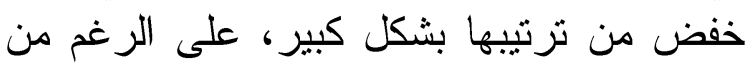

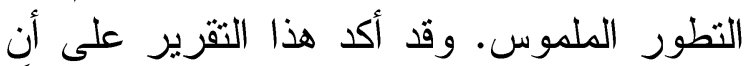

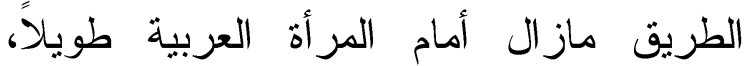
فنصف الإناث في الوطن العربي لا يستطعن

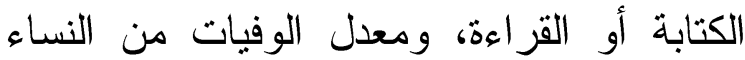

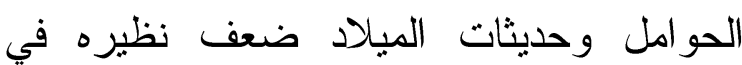

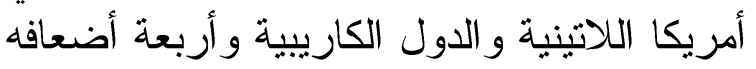

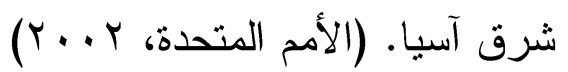

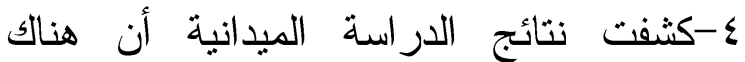

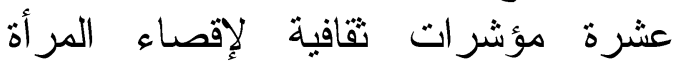

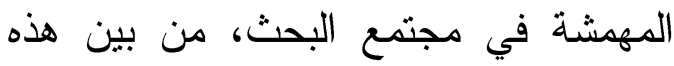

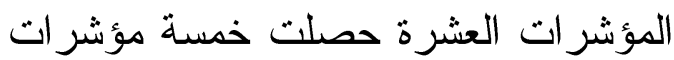

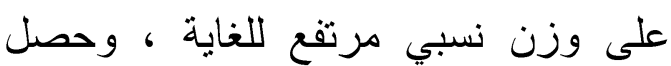
مؤشران على وزن نسبي مرتفع، ونظرة ورنة 


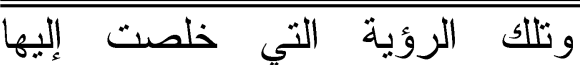

الدراسة الراهنة تفضي بالباحثة إلى القول بأن البهاء

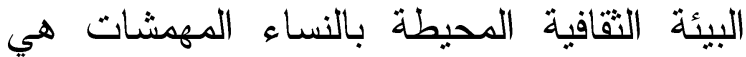
بيئة مضادة للتمكين، سواء بأعر افها أم تقاليدها

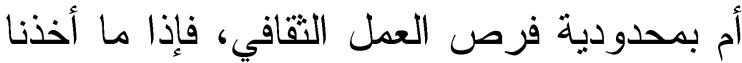

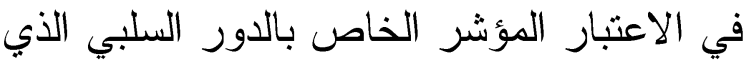

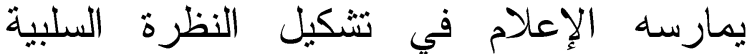
للمر أة، أمكن للباحثة القول إن العناصر الثقافية التقليدية تعمل على تقليل قدر ات المات المر أة وحيازتها

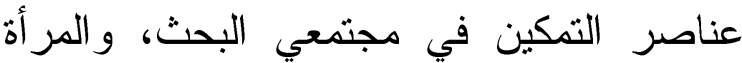
هنا على حد تعبير فاطمة القليني تصبح في حالة فئل حصار ثقافي ، بما بحد من أدوراها وناجئ ويجعلها

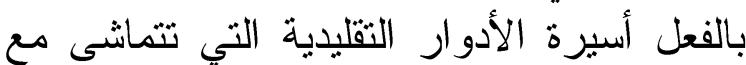

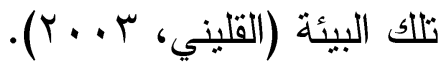

ويبرز المؤشر الخاص بدور الإعلام

السلبي أهمية المؤسسة الإعلامية في تشكيل الصورة النمطية عن المرأة ، بما بعمل على فيلى فيلى

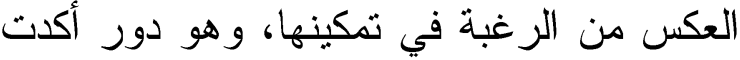

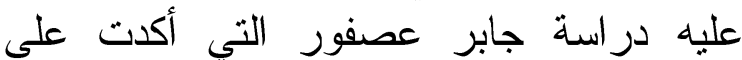

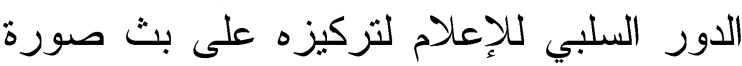

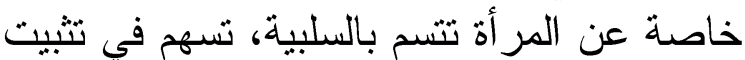
و إثاعة الصورة السائدة عن المرأة التابعة.

$$
\text { ( }
$$

في ضوء ذللك يتحمل الإعلام في

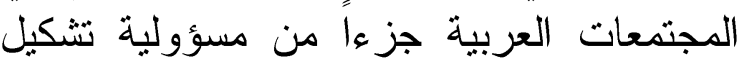

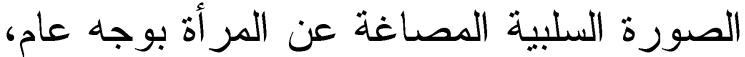
تللك الصورة التي تعزز من حالة الإقصاء التي التي

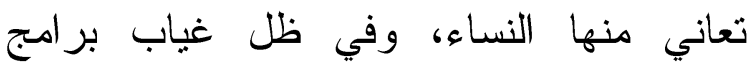
منطورة وفعالة لمحو أمبة الفتاة و والمرأة، وقصور الجهود التطوعية والأجهزة الإعلامية العية عن القيام بدورها في توعية الأسر العربية، الإعلاية وتركيز برامج التعليم على محو الأمية الهجائية دون الأمية الثقافية و الاجتماعية و والقانونية والسياسية ... الخ، يمكن القول بأن والن الآلة الاعلامية لها دور مهم وحاسم في زيادة وتعزيز التوجه نحو إقصاء المرأة في لئ المجنمعات

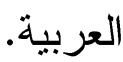

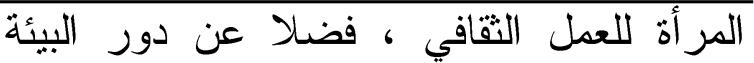

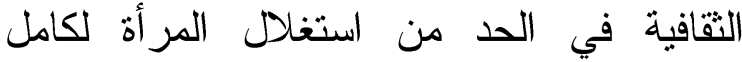

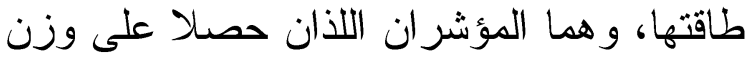

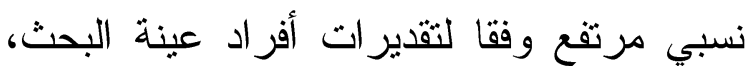

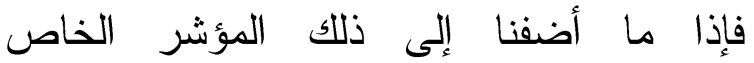
بمحدودية فرص التدريب التي تمكن المرأة من التئ تطوير ذاتها ، ومؤشر دور الإعلام في رسم

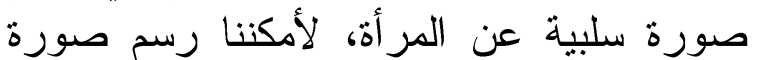

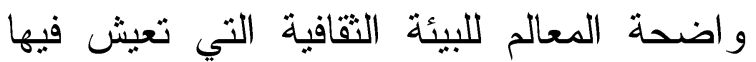
المرأة من أفراد عينة البحث، فهذه البيئة يمكن لفئة أن نطلق عليها مسمي بيئة إقصاء ثقافي. و السؤال الذي يطرح نفسه هنا ما عال علاقة

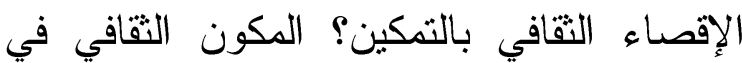
تمكين المرأة مكون لا بمكن تجاهله بأي حال


إبعاد الإقصاء

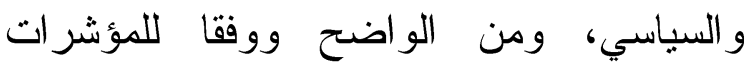
السابقة أن البيئة الثقافية للمر أة المهشئ تكرس نمطا من البناء الثقليدي الذي يدعم الإقصاء عموما بما يتنافى ومقومات التمكين، وربما لإناء تكون تلك البيئة هي الحاضنة الأساسية للإقصاء، بل وتعمل على إعادة إنتاج الأنماط التقافية التقليدية و الثعبية التي تدعم التمايز ضد التداني

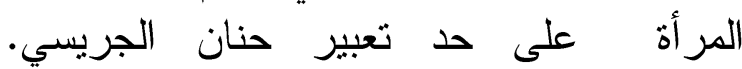

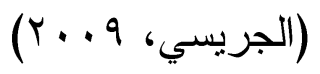

وفي ظل هذا الإطار الثقافي المفعم

بمؤشرات الإقصاء، يمكن القول إن المرأة المأي

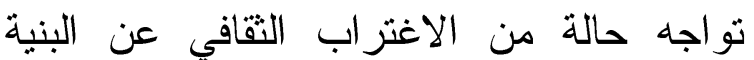

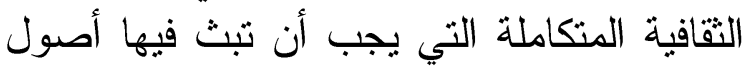
القوة الاجتماعية، كما أثنارت دراسة تهن فنان


البيئة على تكريس نوع من العقلية الإنسانية،

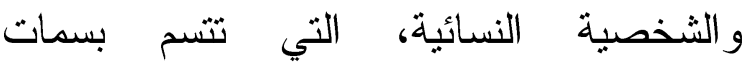
سيكولوجية كالسلبية، و الانسحاب، و الابتعاد عن

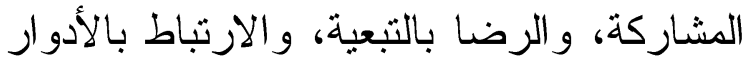

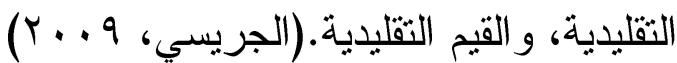


للإقصاء من نساء المناطق الحضرية.

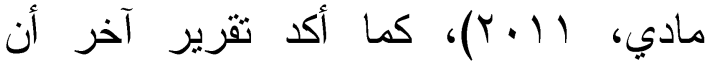
محدودية فرص العمل و التتافس الثديد عليها

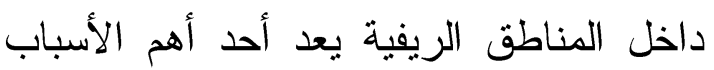

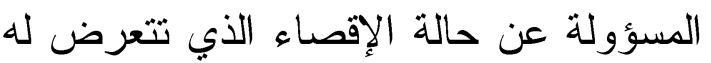

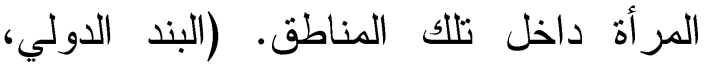

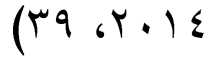

أيضا كثف الاختبار الإحصائي تحليل

التباين أحادي الاتجاه (أنوفا) عن وجواز الإديائ تباين

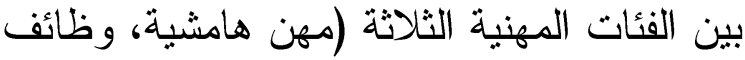

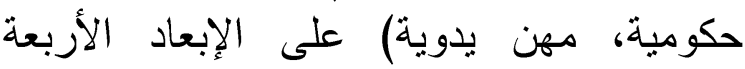

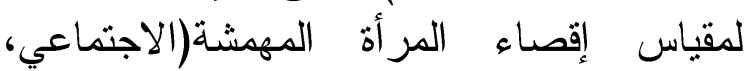
الاقتصادي، السياسي، الثقافي)، وقد جاء اتجاء التهاه

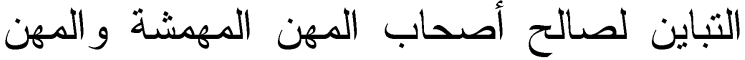
اليدوية في مقابل أصحاب الوظائف الحكومية. وتزى الباحثة أن هذا أمر منطقي في ضواء أبواء

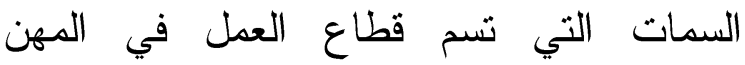
الهامشية والمهن اليدوية، فهذه المهن تقع في في

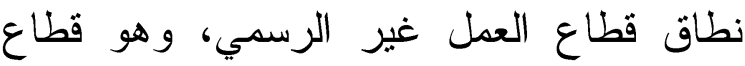

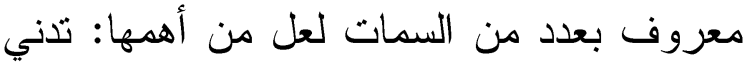

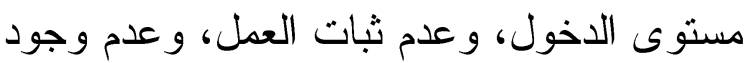

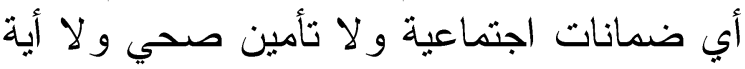
ميزة من المميزات التي يتميز بها لتهات العمل في القطاع الرسمي، ومن ثم فإن العاملين في هذا لفيز

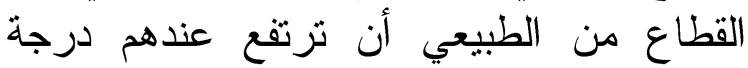

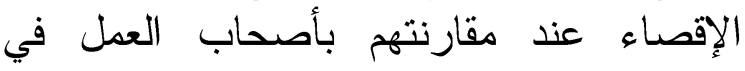

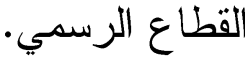 \\ مراجع البحث البثي}

\section{المعاجم والتقارير اللدولية والمحلية:}

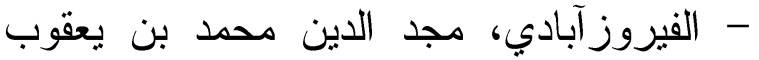

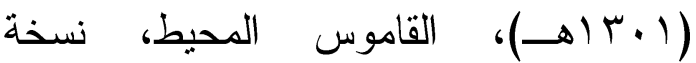
مصورة من الطبعة الثانية للمطبعة الأميرية،

الهيئة المصرية العامة للكتاب، القاهرة.

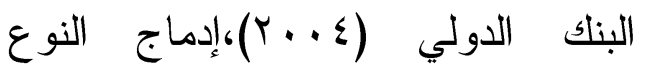
الاجتماعي في التتمية ، ترجمة هشام عبد الله ، الطبعة الأولى. المؤسسة العربية للار اسات

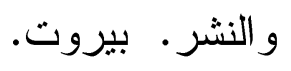

ولعل من أهم النتائج المتزنبة على الهي

سيادة هذا السياق الثقافي، بسطوة أعر افه،

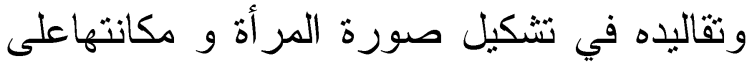

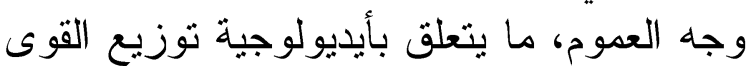

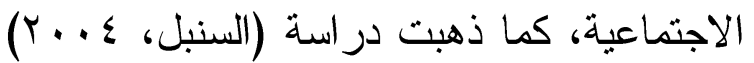

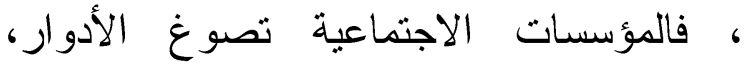

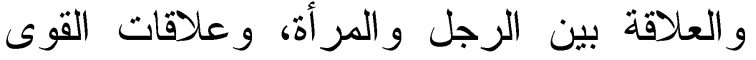

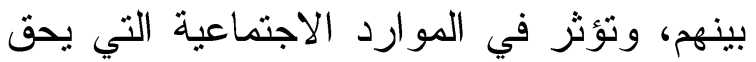

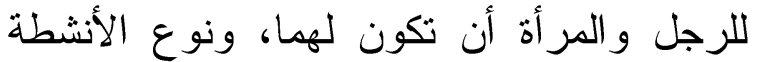

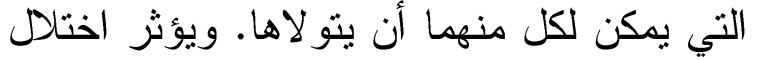

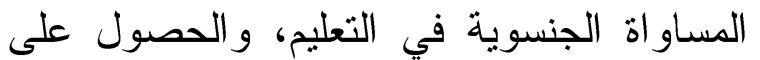

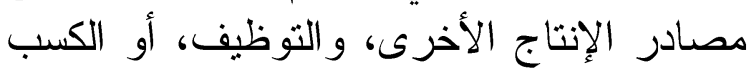

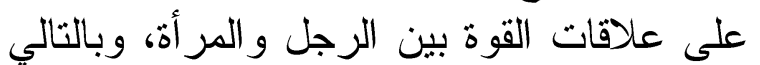

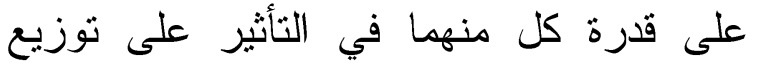

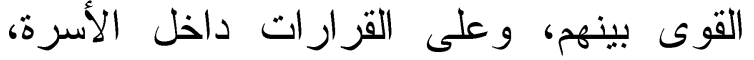

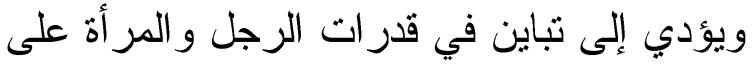

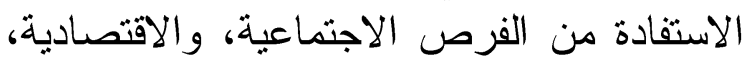

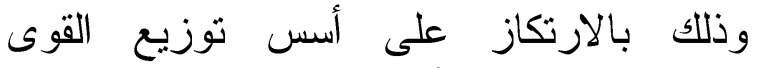
الاجتماعية بين المر أة و الرجل. 0-كثف الاختبار الإحصائي (ت) الندائن أن هناك

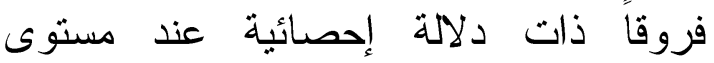

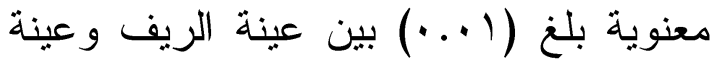

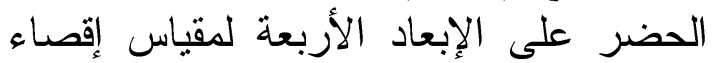

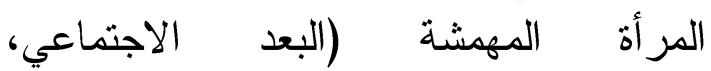

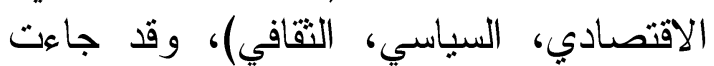
كافة الفروق لصالح عينة الريف؛ مما ليعني الرئي

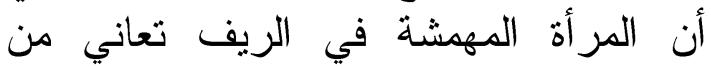

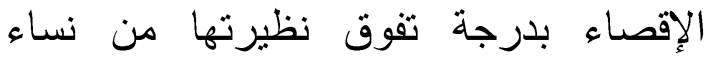

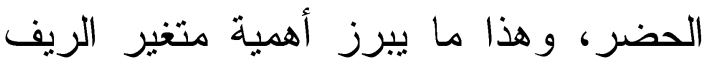

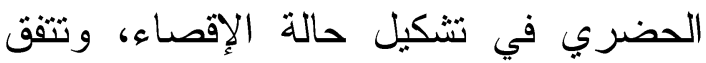

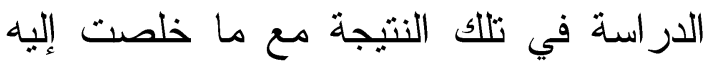

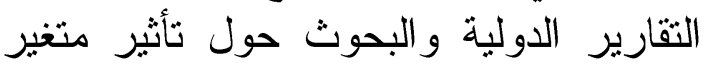
الريف الحضر على عملية الإقصاء الذي تلثي

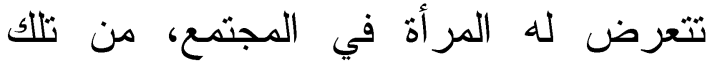

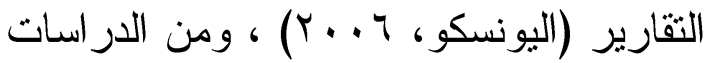

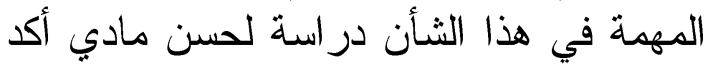
فيها على أن نساء الريف أكثر عرضة مادية 
العمل النشطة، الطبعة العربية، طبع في لمرابئ

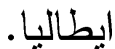

الكتب والدراسات العربية والمترجمهة :

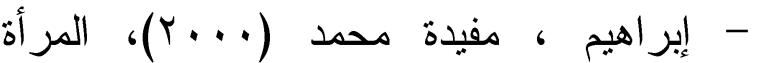

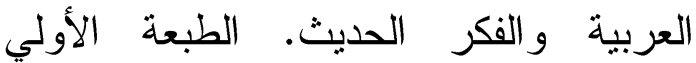
مكنبة مجدلاوي . عمان.

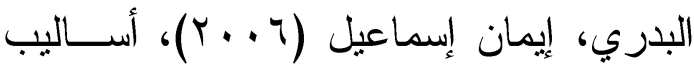

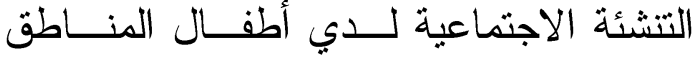

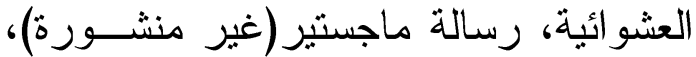

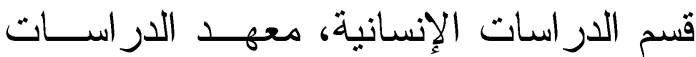
و البحوث البيئية، جامعة عين شمس، القاهرة.

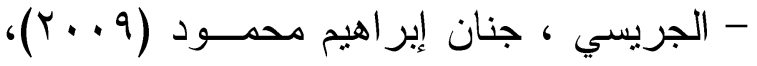
العوامل الاجتماعية و الثقافية المرتبطة المبنة بدور

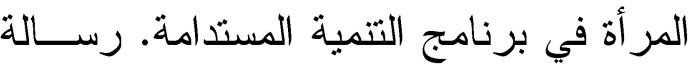

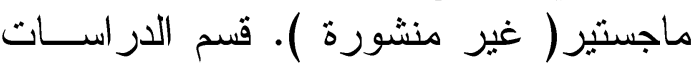
الإنسانية و البيئية. معهد الدر اسات و البحوث

$$
\text { البيئية، جامعة عين شمس. }
$$

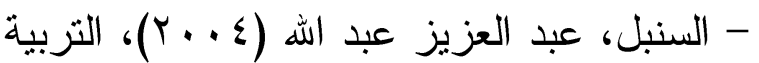

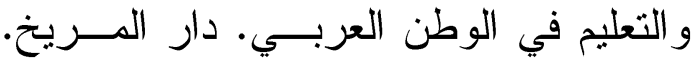

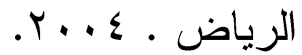

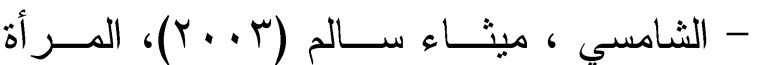

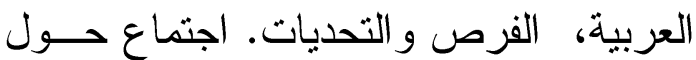
إدماج الإبعاد السكانية في عمليــة التنميــة. اللجنة الاقتصادية والاجتماعية لغربي أسيا الإدان

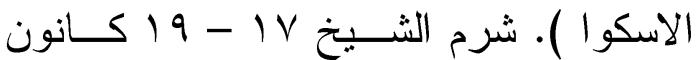

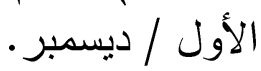

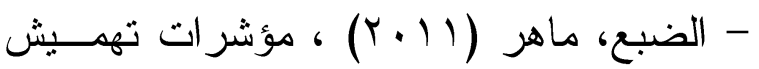

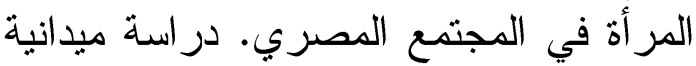

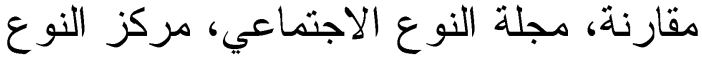
الاجتماعي، جامعة عدن، العدد الخامس.

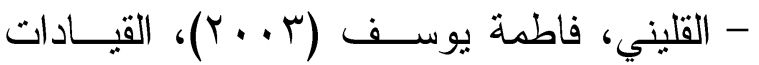
النسائية المصرية وموقفها من بعض قضايا

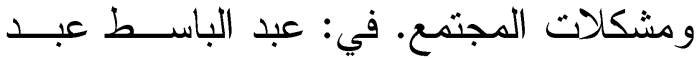

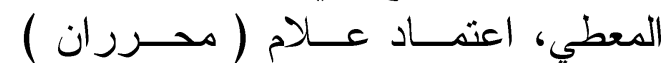

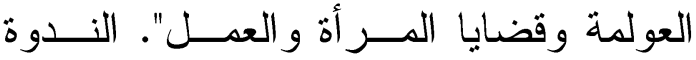
العلمية لمركز الدر اسات و البحوث و الخدمات

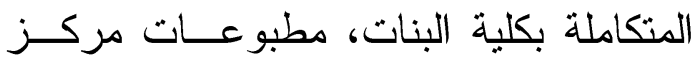

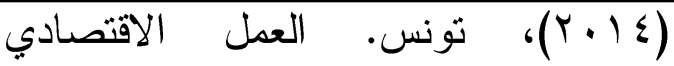

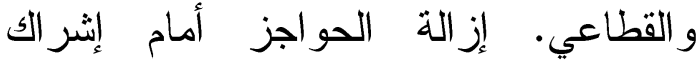
الشباب، الطبعة العربية، تونس.

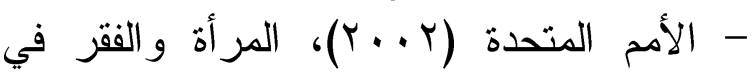
شمال أفريقيا، الاجتماع السابع عشر للجنة الجنة

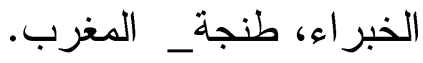
- اللجنة الاقتصادية والاجنماعية لغرب آسيا

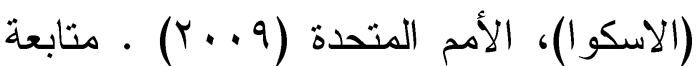

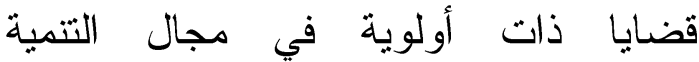

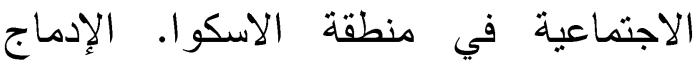

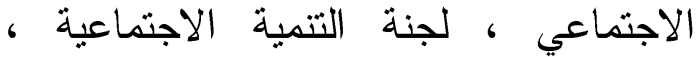

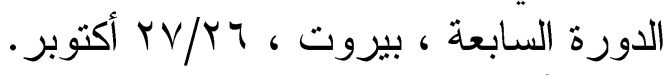

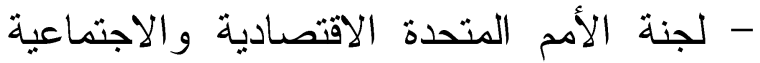

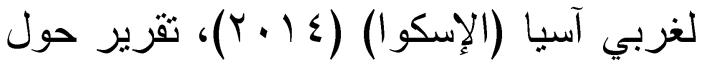

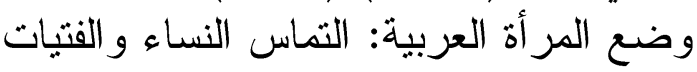

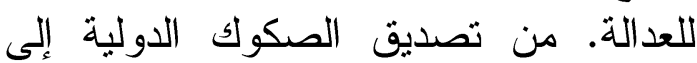

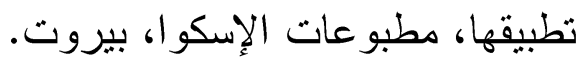

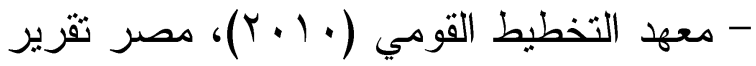
التتمية البشرية " شعباب مصر: بناة المستقبل"، الطبعة العربية، القاهرة.

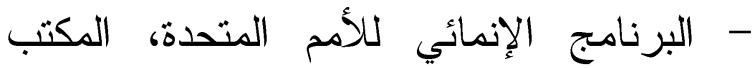

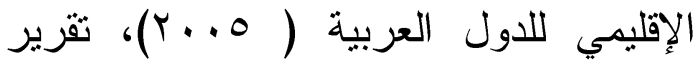

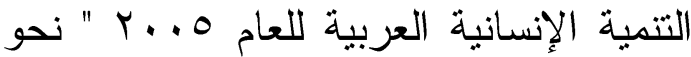

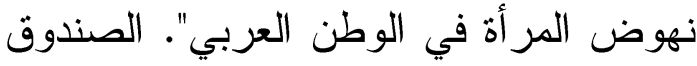

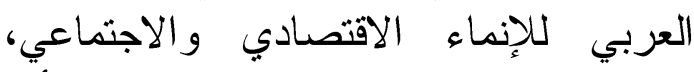

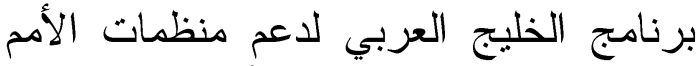

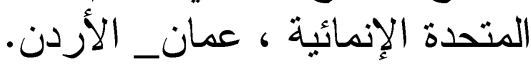
- منظمة الأمم المتحدة للتربية و الثقافة و العلئة الأنوم

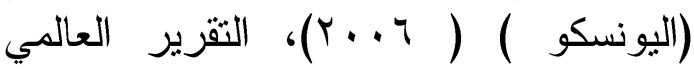

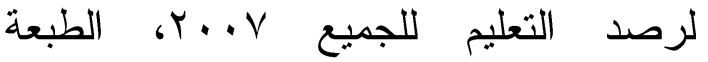

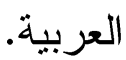

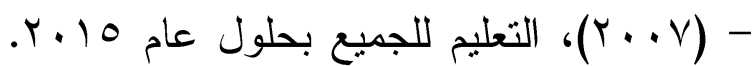
هل سنحقق هذا الهدف؟. الطبعة العربية.

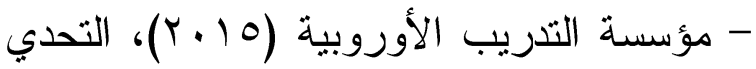
الذي تمثله قابلية الشباب للتوظيف في بلدان حوض المتوسط العربية. دور برامج سوق 


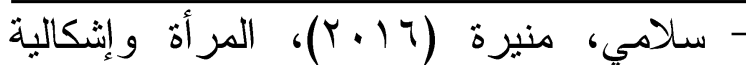

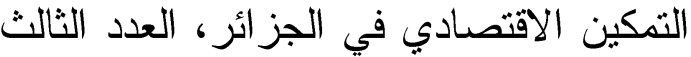

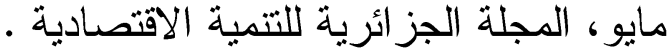

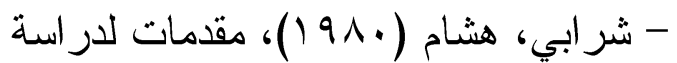

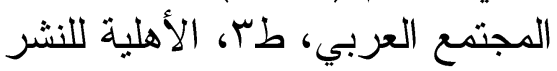
و التوزيع بيروت.

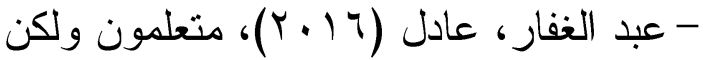
عاطلون عن العمل: معضلة الشباب المصري، مركز بروكنجز ، الدوحة.قطر .

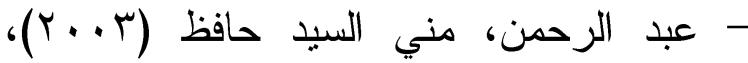
المرأة والمجتمع المدني. في : عبدي الرئ الباسط

عبد المعطي، اعتماد علام ( محرران )

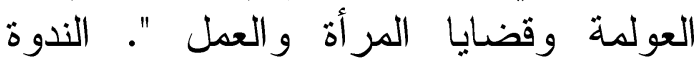
العلمية لمركز الدر اسات و البحوث و الخدمات المتكاملة بكلية البنات ، مطبوعات مركز البحوث و الدر اسات الاجتماعية، جامعة عين شمس. ب - - م مارس.

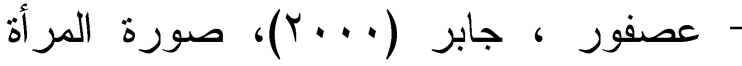

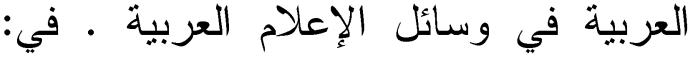

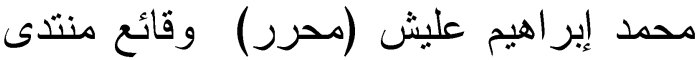

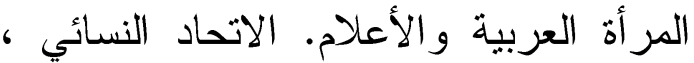

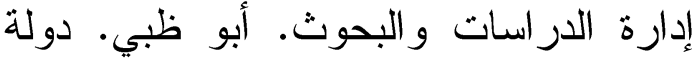
الأمار ات العربية المتحدة.

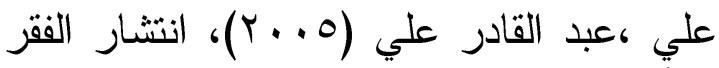

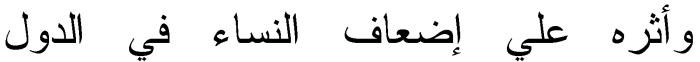
العربية، المعهد العربي للتخطيط ، الكوبه الكويت.

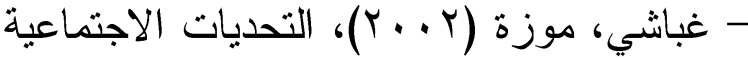

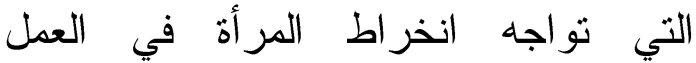

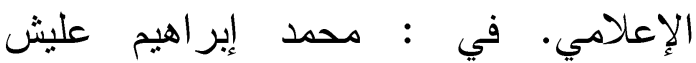

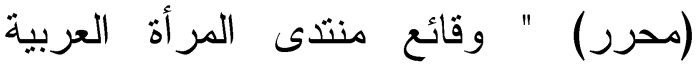
و الإعلام". الاتحاد النسائي ، إدارة الدر اسات

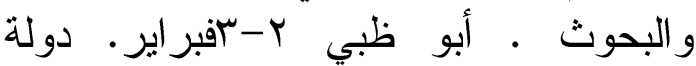

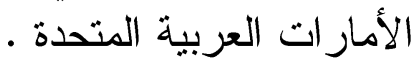

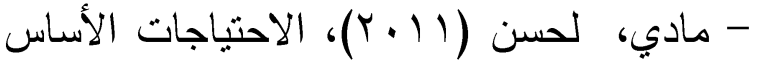
لتعليم النساء. المنظمة الإسلامية للتربية و العلوم و التقافة.
البحوث و الدر اسات الاجتماعية ، جامعة عين شمس. r - شع مارس.

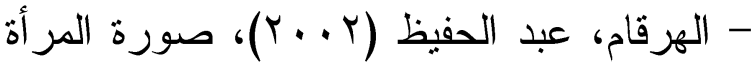
العربية في الأعلام الإذاعي و التلفزيوني.

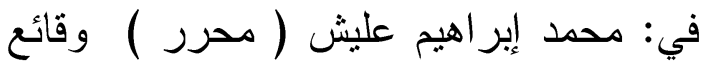
منتدى المرأة العربية والأعلام. الأين الاتحاد

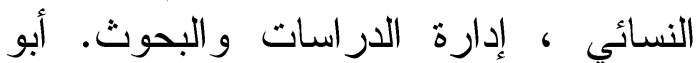
ظبي. دولة الأمار ات العربية المتحدة.

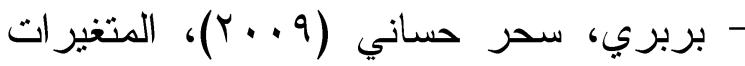
الاجتماعية عن تهميش المرأة الاجتماعي.

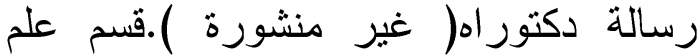
الاجتماع، كلية الآداب، جامعة عين شمس. رله

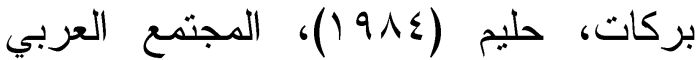

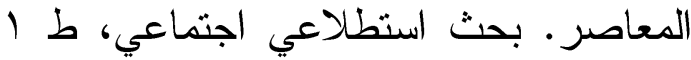
، مركز در اسات الوحدة العربية، بيروت.

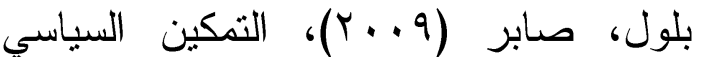
للمرأة العربية بين القرارات و والتوجهات الدولية والواقع، مجلة جامعة دمشق للعلوم

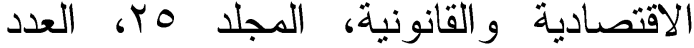
الثاني دمشق.

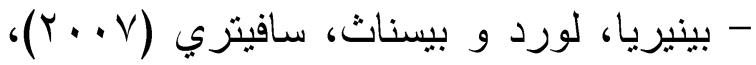

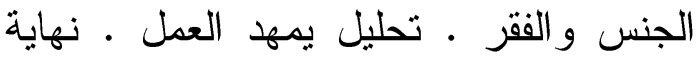
الققر ، جيفري د . ساكس، ترجمة أحمد أمين الجمل، الجمعية المصرية لنشر المعرفة و الثقافة العالمية. القاهرة.

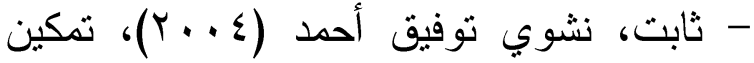

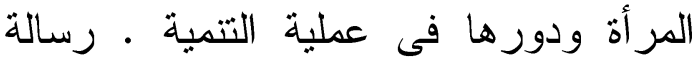

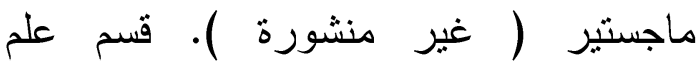
الاجتماع، كلية الآداب ،جامعة عين شمس.

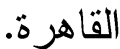
- حافظ، نبيل عبد الفتاح و آخرون ( (... (؟)،

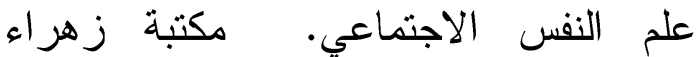
الشرق. القاهرة. - الفن

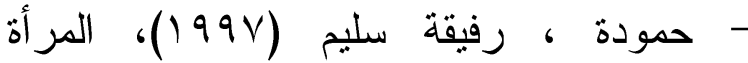
المصرية ، مشكلات الحاضر وتحديات المستقبل. الطبعة الأولي. دار الأمين.

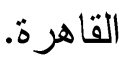


European Journal of Scientific Research. Vol.39 No.1.

- Broembsen, Marlese von (2007), The Legal Empowerment of the Poor: Informal Business, UN.

\section{مواقع إلكترونية: - مونة}

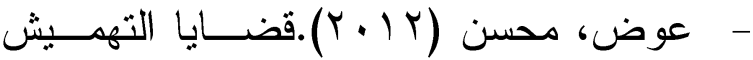

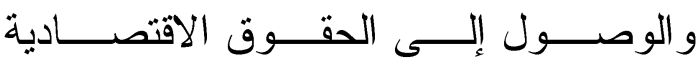

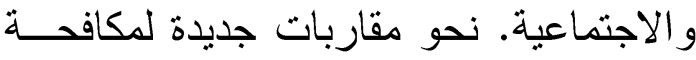
www. dffactory.com

$$
\text { التهميش في العالم العربئ.. }
$$

- بدري، بلقيس (11 ( إ). المساو اة بين الجنسين

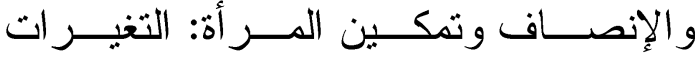

$$
\text { المفاهيمية و القانونية.. الموقع الإنكتروني }
$$

Http://www.escwa.un.org/popin/pubicantion /regional/gender/badir.pdf

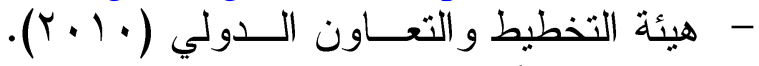
تمكين المرأة ـ الجمهورية السورية.. الموقية الموقع

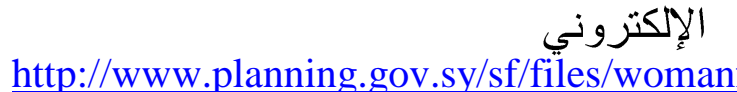
actsandnumbers.fdf

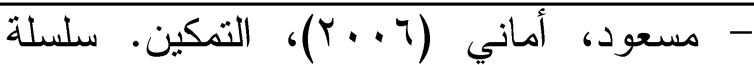

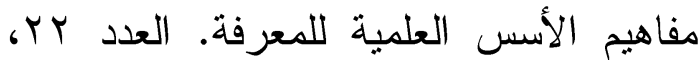

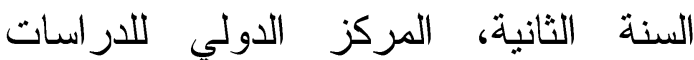
المستقبلية و الاستر اتيجية. القاهرة.

المراجع الأجنبية: - المالية

-Amin , Aloysius Ajab (2006). Capability and Human Development in Poverty Reduction. Dakar, Senegal. Groningen, Netherlands. 4. Online Article: http://ideas.repec.org/ .3-2011.

- Arya, Sadhna (2010), The National Commission for Women: Assessing Performance, India

- Kea G. Tijdens (2010), Are Secondary Part-Time Jobs Marginalized? Job Characteristics of Women Employed Less Than 20 Hours per Week in the European Union, Amsterdam Institute for Advanced Labour Studies AIAS, Department of Economics, University of Chicago.

- Salais, Robert(2007), Social Exclusion and Capability, Lecture delivered at the International Research Conference Marginalization and Social, Exclusion, Alesund, Norway, May 21-23, 2007

- Naz, Iram (2010), Women Empowerment and Youth Perception in Pakistan.

\section{( الملاحق ) ملحق رقم ( )}

\begin{tabular}{|c|c|c|c|c|c|c|c|}
\hline \multicolumn{2}{|c|}{ البعد الرابع } & \multicolumn{2}{|c|}{ البعد الثالث } & \multicolumn{2}{|c|}{ البعد الثاني } & \multicolumn{2}{|c|}{ البعد الأول } \\
\hline درجة & رقم & درجة & رقم & درجة & رقم & درجة & رقم \\
\hline التشبع & العبارة & التشبع & العبارة & التشبع & العبارة & التشبع & العبارة \\
\hline$\cdot . \leqslant V$ & 1 &..$\leqslant \Lambda$ & 1 &.$V I$ & 1 & .00 & 1 \\
\hline..$\leqslant 9$ & $r$ &.$\leqslant 9$ & $r$ & .97 & $r$ & .01 & $r$ \\
\hline .0 & r & .01 & r & .0 & r & .07 & r \\
\hline$\cdot \varepsilon V V$ & $\varepsilon$ & .01 & $\varepsilon$ &..$\leqslant Y$ & $\varepsilon$ &.$\leqslant V V$ & $\varepsilon$ \\
\hline.$\leqslant 0$ & 0 & $.0 \mathrm{~V}$ & 0 & .00 & 0 & $\because \leqslant 0$ & 0 \\
\hline $.0 Y$ & 7 & .07 & 7 &. .01 & 7 & $\because \leqslant V$ & 7 \\
\hline .71 & V &..$\leqslant 9$ & V & س . . & V & $\cdot . \leqslant 7$ & V \\
\hline $.0 \leqslant$ & $\wedge$ & $\cdot . \leqslant \Lambda$ & $\wedge$ & .71 & $\wedge$ & .0 & $\wedge$ \\
\hline .71 & 9 & .0 & 9 & .07 & 9 & $\cdot . \leqslant \wedge$ & 9 \\
\hline $.0 r$ & 1. & 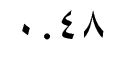 & 1. & $.0 \leqslant$ & 1. & .71 & 1. \\
\hline
\end{tabular}

\section{التحليل العاملي لمقياس إقصاء المرأة}


ملحق رقم (Y) المقياس في شكله النهائي

\begin{tabular}{|c|c|c|c|c|c|}
\hline الإبعاد /العبار ات & \multirow[t]{2}{*}{ s } & الإبعاد /العبار ات & \multirow[t]{2}{*}{ r } & الإبعاد / العبار ات & \multirow[t]{2}{*}{ r } \\
\hline البعد الر ابع_ الإقصاء التقافي & & & & الاجتماعي الأول- الإقصاء & \\
\hline الألكور بتمام بتعليم البنات أقل من تعليم الاو لاد & 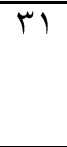 & 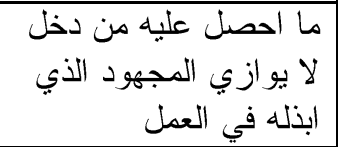 & 17 & الاجتماعية محدودة في المناسبات & 1 \\
\hline الو لاد دون الاناث & Tr & |الاخل الذي احصل عليه & IV & هو ألغالب في كل الألة الأسرة & $r$ \\
\hline 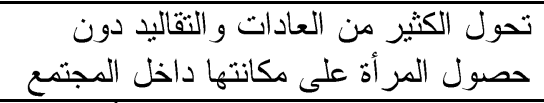 & r & الأعمال التي تحصل النيا مؤقتة & 11 & للغاية مقارنة باخوتي الذكور & $\mu$ \\
\hline الممارسة على نطاق واسيع داخل الأسر من الأمور & $r \varepsilon$ & 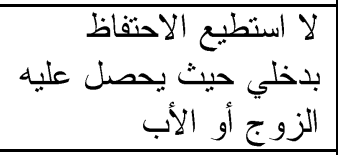 & 19 & استقلال عن اسرتها تحقق المر أة & $\varepsilon$ \\
\hline التقافي العام ما زالت متدام المر أة للممارسة العمل & ro & 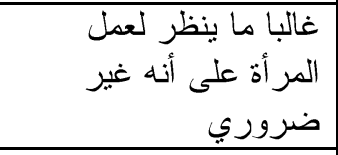 & $r \cdot$ & الخيود داخل المر أة للعديد من & 0 \\
\hline فرص المر أة بوجه عام المطلة على الحياة تقلل من & ru & |البعد الثالث- الإقصاء & & تربية البنات لا تساعد المسولية منفردة & 7 \\
\hline 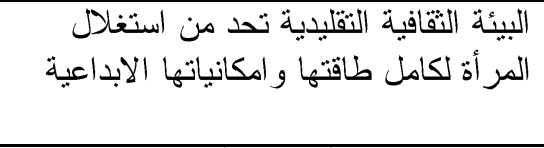 & TV & |السياسيةً ضعيف للغاية & r) & التحكم باقي الفر ادها من الأسرة & V \\
\hline 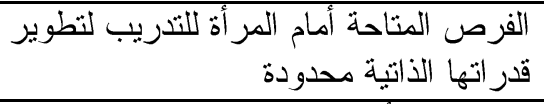 & $r \Lambda$ & في الانتخابات ضعيف التصويت & $\overline{Y Y}$ & لا لا يمكن مخالف تقاليد الأسرة & $\lambda$ \\
\hline مؤسسات الدولة أن اهنتام ضعيف ضن من قبل & rq & انشطة أبي جمعية أهلية أنشارك مطلية في & $r \mu$ & كنظو من المجتمع لر أي المر أة & 9 \\
\hline ليساهم الاعلام برسم صورة سلبية عن & $\varepsilon$ & 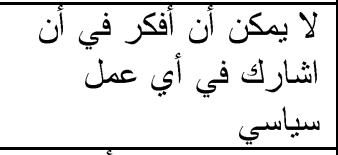 & Ys & الإلكور سيطرة افر الأسرة من على & 1 \\
\hline & & للغاصلة العباسي المر أة في & ro & الاقتصادي الثاني- الإقصاء & \\
\hline & & العمل السياست للتفكير في الحياة لا نترك & $\overline{r t}$ & فرلبلة مقارنة بالرجال المتاحة للمر أة & 1 \\
\hline & & | المجالس المحلية ضعيفة أمية في & TV & 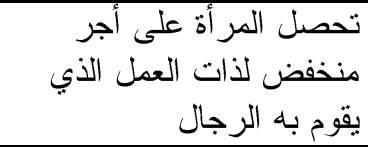 & $\begin{array}{r}\text { r } \\
\text { r }\end{array}$ \\
\hline & & | معرفتي بالحقوق السياسية للمر أة متدنية & YA & فرد ذات دصول المر أة على & 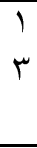 \\
\hline & & 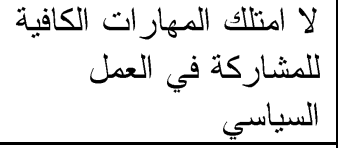 & rq & تحصى أعمال متدنية المر في الغالب & 立 \\
\hline & & 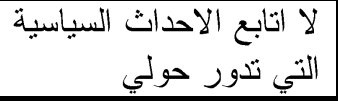 & $r$. & لا استطيع الادخار من دخلي & \\
\hline
\end{tabular}



